André Rocha Sampaio

Joane Marcelle de Oliveira e Silva

Marcelo Herval Macêdo Ribeiro

Marcos Eugênio Vieira Melo

(Organizadores)

\title{
Anais do II Encontro Nordestino de Pesquisa em Ciências Criminais
}




\section{Sumário}

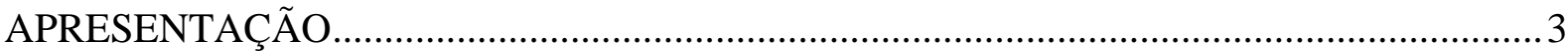

O INTERROGATÓRIO POR VIDEOCONFERÊNCIA COMO FORMA DE CELERIDADE NO PROCESSO PENAL E GARANTIA DA ORDEM PÚBLICA.............................................5

O CRIME DE IMPORTUNAÇÃO SEXUAL: UMA ANÁLISE DO ARTIGO 215-A DO CÓDIGO PENAL, INCLUÍDO PELA LEI N ${ }^{\circ}$ 13.781/2018 ................................................. 18

A DESUMANIZAÇÃO CARCERÁRIA COMO CAUSA DA INEFICÁCIA DA PENA .....31 A INTERVENÇÃO DOS PARTICULARES NO SISTEMA PENITENCIÁRIO BRASILEIRO E OS POSSÍVEIS REFLEXOS DA INSUFICIÊNCIA DE PREVISÃO LEGAL

A RELAÇÃO ENTRE OS DIREITOS FUNDAMENTAIS E A RESSOCIALIZAÇÃO EM MEIO AO ENCARCERAMENTO EM MASSA

OS REFLEXOS DO ENCARCERAMENTO EM MASSA NA GARANTIA DOS DIREITOS FUNDAMENTAIS DOS DETENTOS

PRIVATIZAÇÃO DAS PRISÕES: OS POSSÍVEIS REFLEXOS NAS POLÍTICAS DE ENCARCERAMENTO EM MASSA NO BRASIL 


\section{APRESENTAÇÃO}

O ano de 2018 foi politicamente um ano bastante conturbado. Do assassinato da então vereadora Marielle Franco e de seu motorista Anderson, em 14 de março, até a eleição inicialmente improvável do ex-deputado Jair Messias Bolsonaro. Enquanto isso, a educação pública agonizava; após sucessivos cortes e limitações instituídas pelo governo neoliberal de Michel Temer, o pouco da plataforma política do candidato vencedor era muito pouco alvissareira para a ciência brasileira. Foi diante desse cenário que ocorreu a segunda edição do Encontro Nordestino de Pesquisa em Ciências Criminais, oportunidade na qual foram realizadas quatro mesas: Criminologias Alternativas, Processo Penal Crítico, Execução Penal e, não poderia faltar, uma mesa com diálogo referente ao extermínio da população negra no Brasil, com destaque ao assassinato de Marielle Franco e Anderson Silva.

Ademais, as/os interessadas/os puderam enviar resumos para três grupos de trabalho: Ciências criminais e marcadores interseccionais: gênero, raça e classe; processo penal em crítica e governamentalidade; Sociedade punitiva e cultura do controle. Nessa edição pudemos contar com representantes de Pernambuco, Paraíba, Maranhão, Alagoas e uma convidada do Rio de Janeiro, de modo a mantermos o diálogo da pesquisa regional com o que vem sendo trabalhado nos grandes centros nacionais. Dos resumos aprovados, ao cabo, sete artigos foram enviados e compõem a presente edição, com temáticas que orbitam em torno do direito penal e do processo penal, e são indicativos do que se vem pesquisando na região.

Tal qual a primeira edição, esta segunda representa uma grande vitória para o Grupo de Pesquisa Biopolítica e Processo Penal, que, com todas as limitações econômicas pelas quais o sistema de ensino atravessa, conseguiu montar um evento de qualidade, dando continuidade à grande missão do Encontro: dar voz a um segmento de pesquisadores tão pouco divulgados em âmbito nacional, de modo que se possa integrar sua pesquisa em ciências criminais e estabelecer pontes de cooperação tanto locais quanto nacionais, tendo como horizonte um incremento na pesquisa nacional.

Maceió, verão de 2020. 
GT 1 


\title{
O INTERROGATÓRIO POR VIDEOCONFERÊNCIA COMO FORMA DE CELERIDADE NO PROCESSO PENAL E GARANTIA DA ORDEM PÚBLICA
}

\author{
THE INTERROGATORY FOR VIDEO CONFERENCE AS A FORM OF CELERY IN \\ THE CRIMINAL PROCESS AND GUARANTEE OF THE PUBLIC ORDER
}

\author{
José Eurico Beltrão Coelho da Paz Neto ${ }^{1}$ \\ Luiz Matheus Marques de Góis ${ }^{2}$
}

\begin{abstract}
RESUMO: Este trabalho explora a realização do interrogatório por meio da videoconferência. Defende-se que os recursos tecnológicos são utilizados para robustecer a justiça brasileira, de forma a corroborar com os princípios da duração razoável do processo, garantia da ordem pública e economicidade. A questão enfrentada para a plena aplicação desse instrumento perpassa pela demonstração do respeito aos direitos de defesa do acusado. Nessa perspectiva, o trabalho busca analisar o tema através da investigação de aspectos causais, suas consequências, em que conteúdo teórico tem como base artigos científico e pesquisas bibliográficas.
\end{abstract}

Palavras-chaves: Videoconferência; duração razoável do processo; ordem pública; economicidade; ampla defesa.

\begin{abstract}
This paper explores the conduct of the interrogation through videoconference. It is argued that technological resources are used to strengthen the Brazilian justice, in order to corroborate with the principles of reasonable process duration, public order guarantee and economy. The issue faced by the full application of this instrument is the demonstration of respect for the defendant's rights of defense. In this perspective, the work seeks to analyze the theme through the investigation of causal aspects, its consequences, in which theoretical content is based on scientific articles and bibliographical researches.
\end{abstract}

Keywords: Video conference; reasonable duration of the proceedings; public order; economicity; defense.

\section{INTRODUÇÃO}

\footnotetext{
${ }^{1}$ Estudante de Direito do Centro Universitário Tiradentes. E-mail: netobeltrao@ hotmail.com

${ }^{2}$ Estudante de Direito do Centro Universitário Tiradentes. E-mail: luiz-gois2011@ hotmail.com
} 
A morosidade do judiciário brasileiro é notória, aliada a essa questão encontra-se o estado caótico em relação à segurança pública. Desta feita, faz-se necessário compreender e aprofundar os estudos em uma área que é gradativamente explorada pelo sistema judiciário, o campo tecnológico, almejando as formas que os recursos tecnológicos possam robustecer a justiça brasileira.

Nesse sentido, fora editada a Lei 11.900/2009, cujo objetivo é regulamentar os interrogatórios e outros atos no processo penal por meio do sistema da videoconferência. Tal legislação trata o recurso tecnológico como mecanismo subsidiário para a efetivação da garantia da ordem pública e da celeridade processual, na medida a realização de atos por meio desse aparato é realizada de forma excepcional, de acordo os as hipóteses previstas na lei. Entretanto, é de suma importância realizar o estudo da aplicação desse aparato em coadunação com uma análise futura de ampliação dessa sistemática.

Na prática a utilização da videoconferência, para realização de interrogatórios com réu preso, apresenta-se como: ferramenta garantidora da celeridade no processo penal, na medida em que diversos casos a audiência deixa de ser realizada em virtude do não recambiamento dos presos para o fórum, o que o ocasiona um prolongamento da instrução processual por uma questão de logística; forma de economia ao erário, visto que o deslocamento do preso para audiência proporciona um gasto tanto com o deslocamento propriamente dito, como com a segurança para com o preso e à sociedade; e representa uma maior segurança à população, já que inexiste o risco de fuga durante o trajeto à audiência, além de que, a situação do escasso número de agente prisionais para com o número de presos é notória, proporciona o não decréscimo do efetivo de agentes carcerários trabalhando no presidio.

A grande questão a ser enfrentada para a efetiva implantação desse mecanismo passa pela demonstração do respeito aos direitos de defesa do acusado, sobretudo no que diz respeito aos princípios da publicidade e da ampla defesa, e se nesse caso não haveria uma inconstitucionalidade da lei já mencionada. Na medida em que se tem argumentado que o fato do réu não estar presente fisicamente perante o juiz, durante o seu interrogatório, poderia de certa forma macular tal garantia constitucional. Tal parcela de entendimento cita como exemplo a falta de visualização, por parte do juiz, de qualquer interferência externa, com relação ao acusado que estará no sistema prisional.

Diante dos fatos, faz-se necessária uma otimização da ferramenta que está à disposição da justiça, de forma que corrobore com os princípios da celeridade processual e garantia da ordem pública, ao passo que sempre respeite e garanta os direitos fundamentais do acusado. 
Este trabalho foi desenvolvido, de forma a expor as características e as consequências do tema na sociedade e atingir a maior aproximação possível no processo de conhecimento da problemática existente, tendo como base artigos científicos e pesquisas bibliográficas.

Inicialmente faz-se necessário uma exposição da legislação jurídica que trata da utilização da videoconferência nos atos processuais penais, como também dos princípios que vão ser corroborados com a utilização desse mecanismo tecnológico. Em seguida, o trabalho trata de pontos que suscitam uma divergência acerca da utilização deste aparato, tratando sobre os direitos de defesa do acusado. Por fim, o tema é abordado sobre a perspectiva da constitucionalidade da sua regulamentação legal e a necessidade de ampliação desse sistema.

\section{A VIDEOCONFERÊNCIA SOB A ÓTICA DO DIREITO BRASILEIRO}

\subsection{A videoconferência na legislação brasileira (Lei 11.900/2009)}

É notório o desenvolvimento tecnológico de ferramentas que auxiliam os homens em suas atividades diárias. Nesse passo, a introdução de mecanismos tecnológicos na área jurídica é um movimento natural de aperfeiçoamento da dinâmica jurídica. Entretanto, no Brasil, a questão sempre foi tema de debates e divergências na jurisprudência, somente com a Lei 11.900, em 2009, alterando os artigos 185 e 222 do Código de Processo Penal (CPP) e acrescentando o art. 222- $\mathrm{A}^{3}$, é que fora regulamentado o interrogatório e outros atos no processo penal por meio do sistema da videoconferência.

As inovações trazidas, no âmbito da realização dos interrogatórios, foram colocadas de forma excepcional, ou seja, em regra continua-se a se realizar o interrogatório do réu perante a autoridade judiciária, na presença de seu defensor, conforme preleciona o artigo 185, caput do CPP.

Tal excepcionalidade se dará para colher o depoimento do réu preso por meio do sistema de videoconferência ou outro recurso tecnológico de transmissão de sons e imagens em tempo real - atualmente há inúmeros aplicativos que permitem tal transmissão, a exemplo do Skype - . A execução dessa situação será legítima somente se houver decisão fundamentada

\footnotetext{
${ }^{3}$ JUS BRASIL. Interrogatório por videoconferência. Disponível em: <flaviocardosooab.jusbrasil.com.br/artigos/112232345/interrogatorio-por-videoconferencia>. Acesso em: 12 ago. 2018.
} 
do juiz, de ofício ou a requerimento das partes, caso tal medida seja o meio para alcançar as finalidades trazidas nos incisos do parágrafo segundo do mencionado artigo 185, que têm as seguintes redações:

I - prevenir risco à segurança pública, quando exista fundada suspeita de que o preso integre organização criminosa ou de que, por outra razão, possa fugir durante o deslocamento;

II - viabilizar a participação do réu no referido ato processual, quando haja relevante dificuldade para seu comparecimento em juízo, por enfermidade ou outra circunstância pessoal;

III - impedir a influência do réu no ânimo de testemunha ou da vítima, desde que não seja possível colher o depoimento destas por videoconferência, nos termos do art. 217 deste Código;

IV - responder à gravíssima questão de ordem pública.

Tratando sobre o assunto, Rosmar de Alencar assevera que "com o advento da Lei 11.900/2009, a videoconferência, como instrumento para servir ao meio de prova oral, passou a ser utilizada sem controvérsia. O requisito para seu uso há de ser excepcional, tal como se depreende do atual texto do $\S 2 .^{\circ}$ do art. 185. do CPP" 4 .

Assim, para que se possa realizar o interrogatório por videoconferência faz-se necessário que haja algumas dessas hipóteses mencionadas. Caso contrário, o interrogatório será realizado perante o juiz.

\subsection{Dos princípios corroborados com a videoconferência}

Nota-se que o legislador, ao editar a mencionada Lei 11.900/2009, preocupou-se com a celeridade processual, ao permitir que atos processuais fossem realizados de maneira mais ágil, e com a garantia da ordem pública, evitando fugas dos presos durante o trajeto para a audiência ou a influencia do réu para com a vítima. Além da economicidade, na medida em que há uma economia do erário uma vez que não há os custos com o deslocamento.

Desta forma, a fim de realizar o interrogatório do réu de forma mais segura, menos onerosa, ao mesmo tempo em que traz uma celeridade para o processo, faz-se necessário interpretar tais princípios mencionados de forma sistemática e conjunta ${ }^{5}$.

\footnotetext{
${ }^{4}$ ALENCAR, Rosmar Antonni Rodrigues Cavalcanti. Informática jurídica e tecnologia no processo penal. Revista dos Tribunais, [S.L], v. 940, p. 283 - 306, fev. 2014.

5 GOMES, Rodrigo Carneiro. A LEI 11.900/2009 E A ADOÇÃO DA VIDEOCONFERÊNCIA NO

BRASIL. Revista dos Tribunais, [S.L], v. 892, p. 403-424, fev. 2010.
} 


\subsubsection{Duração razoável do processo penal}

A Constituição Federal de 1988 dispõe em seu artigo 5², LXXVIII, que é assegurado a todos a razoável duração do processo e os meios que garantem a celeridade de sua tramitação. Assim, a carta constitucional assegura as partes do processo, em sentido amplo, que a situação não deverá se perdurar por anos e anos.

Dissertando sobre o assunto Rosmar de Alencar e Nestor Távora aduzem que "ao estabelecer, no artigo $5^{\circ}$, inciso LXXVIII, da Carta Magna, o principio da razoável duração do processo, almeja-se evitar dilações processuais indevidas, criando-se uma espécie de tempo virtual, como parâmetro para a extensão do processo" ${ }^{6}$. Entretanto, em que pese haver legislação tratando de limites temporais para a realização da instrução, não fora definido uma sanção em caso de descumprimento. Assim, pela analise do ordenamento jurídico brasileiro nota-se que foi adotada a "teoria do não prazo", ou seja, não há um prazo predeterminado do curso do processo e a análise deverá ser feita à luz do caso concreto ${ }^{7}$.

A realização do interrogatório do réu é o último ato da instrução processual, o que significa dizer que vítimas e testemunhas do caso, seja de acusação ou de defesa já foram ouvidas. Sendo o réu intimado da audiência e não comparecer, será declarada a sua ausência da audiência, perdendo o direito de falar perante a autoridade judicial.

Entretanto, sendo o réu preso e este não comparecendo a audiência a situação implica em consequências diferentes. Visto que como a ausência do réu não se originou de vontade própria e sim por alguma situação que não permitiu o seu transporte ao fórum naquele dia em questão, deverá ser marcada uma nova data para realização de sua qualificação e interrogatório.

Tal fato na prática ocasiona a morosidade do judiciário, na medida em que há um prolongamento da instrução processual. Conseguir alocar o interrogatório do réu em uma nova data próxima é uma tarefa difícil, já que as pautas das varas criminais são cheias e dificilmente há disponibilidade de datas próximas.

Assim, como exemplo, à instrução que deveria ter terminado em agosto é marcado uma nova data para setembro e neste dia, por uma situação semelhante que motivou a não

${ }^{6}$ TÁVORA, Nestor; ALENCAR. Curso de Direito Processual Penal. 12. ed. Salvador: Editora JusPodivm, 2017. p. 92.

${ }^{6}$ IDEM, IBIDEM. p. 92. 
finalização da instrução, não é realizado o interrogatório do réu, sendo necessário ser marcada uma data para novembro.

Nesse sentido, a utilização da videoconferência torna a instrução mais célere, visto que essas situações mencionadas não ocorrerem, ou seja, os motivos ensejadores da ausência do réu preso ao interrogatório não existem. Desta feita, a utilização desse recurso tecnológico corrobora para a concretização do direito fundamental de duração razoável do processo.

\subsubsection{Garantia da Ordem pública}

É notória a situação caótica encontrada pelos agentes carcerários nos presídios brasileiros, uma vez que o número de agentes é totalmente inferior ao mínimo razoável em relação aos números de presos. Nessa lógica, ao mesmo tempo em que a realização do interrogatório por meio da videoconferência coíbe fugas durante o deslocamento, já que este inexistirá, também corrobora para uma maior segurança dentro dos presídios, posto que o efetivo de agentes não será reduzido. Convém destacar que além dos riscos de fuga durante o trajeto há o risco de fuga dentro do próprio fórum, na medida em que esses locais não contam com segurança adequada.

Ora, se na maioria dos casos o motivo do não recambiamento do preso à audiência se dá pelo baixo efetivo de agentes carcerários, realizando uma interpretação sistemática, a realização do interrogatório por meio da videoconferência garante a celeridade do processo ao passo que garante a segurança tanto para à sociedade como também para o próprio preso.

\subsubsection{Economicidade}

O artigo 70 da Carta constitucional prevê o princípio da economicidade. Tal postulado significa que o Estado deve buscar garantir a prestação dos seus serviços aliada a um custo baixo quanto possível. Dessa forma, o transporte de presos à audiência é uma afronta a essa norma constitucional à proporção que os custos com o trajeto são altos, demandando certo investimento para garantir a segurança durante o caminho, como também no próprio Fórum.

Nessa perspectiva, Rodrigo Carneiro Gomes cita como exemplo o levantamento feito pelo deputado federal Otávio Leite que demonstrou que as escoltas de criminosos, em 
atendimento às imposições da Justiça, geram um gasto de 1,4 bilhão de reais anualmente aos cofres publico.

Desta feita, a concretização do interrogatório por meio da videoconferência coadunase com o princípio da economicidade na medida em que os custos com esse mecanismo tecnológico são baixos, apenas deve se destinar uma pequena quantidade para a manutenção do aparato tecnológico. Portanto, há uma economia do erário com a realização da videoconferência a haver deslocamento físico do preso para a audiência.

\section{DOS DIREITOS DE DEFESA DO ACUSADO}

\subsection{Da ampla defesa e do contraditório}

Apesar de estarem intimamente ligados, os princípios da ampla defesa e do contraditório se divergem. O primeiro refere-se ao direito do acusado de apresentar todos os meios de prova, obtidos por meio lícito, para provar sua inocência ${ }^{8}$. Vale ressaltar que há exceções que permitem o reconhecimento de prova obtida por meio ilícito, como por exemplo: se tal prova se revelar como única apta a provar a inocência do réu. Já o segundo trata-se do direito do acusado de ter conhecimento dos fatos e ter a possibilidade de contraditar tudo que foi dito pela outra parte ${ }^{9}$.

A observação desses princípios coaduna-se para a concretização do devido processo legal. Assim, é necessário atentar para o termo processo, ou seja, tais garantias constitucionais previstas no art. $5^{\circ}, \mathrm{LV}$ da Carta Constitucional não se aplicam para a fase de Inquérito Policial, na medida em que esse instituto investigativo possui característica inquisitiva e natureza administrativa.

Nessa perspectiva, há quem defenda que a realização do interrogatório do réu por meio da videoconferência fere tais princípios constitucionais, pois, por exemplo, não permitiria ao juiz perceber possíveis pressões externas que pudesse interferir na oitiva do acusado. Seguindo essa linha, Aury Lopes Jr. ${ }^{10}$ aduz que a determinação de utilização dessa ferramenta impede ao

\footnotetext{
8 PAULO, Vicente; Alexandrino, Marcelo. Direito Constitucional descomplicado. 14. ed. Rio de Janeiro: Forense; São Paulo: Método, 2015. p. 190.

${ }^{9}$ IDEM, IBIDEM. p. 191.

${ }^{10}$ LOPES JUNIOR, Aury. Direito processual penal. 11a ed. São Paulo: Saraiva, 2014. p. 662.
} 
réu de assistir toda a instrução, o que geraria um problema para a efetivação do contraditório e do direito de defesa nessas condições.

Entretanto, majoritariamente, entende-se que tais princípios são respeitados, na medida em que o réu irá ser ouvido pela autoridade judicial acompanhado de dois defensores, um ao seu lado no presídio e o outro ao lado do juiz. Além de que a transmissão é feita simultaneamente, permitindo o contato audiovisual do juiz com o acusado. Assim, é permitido ao réu contrariar todas as provas que foram produzidas perante o juiz da causa, ao passo em que pode se defender amplamente ${ }^{11}$. Vale ressaltar que o acusado pode se comunicar reservadamente tanto com o defensor que estará com ele no presídio, como com o defensor que estará à distância.

No que diz respeito à questão trazido pelo doutrinador Aury Lopes Jr. a questão pode ser resolvida com a disponibilização da transmissão de toda a instrução para o preso, ou seja, inicia-se a chamada de vídeo antes do interrogatório e ao preso é disponibilizado o áudio e a imagem de tudo que se passa na audiência ao vivo, visto que os equipamentos, quais sejam câmeras e microfones, permitem a captação audiovisual perfeita.

\subsection{Da publicidade}

Sob a ótica dos autores Nestor Távora e Rosmar de Alencar "a publicidade é a permissibilidade de acesso aos autos processuais conferida a todos os interessados" ${ }^{12}$. Assim, a publicidade dos atos é a regra e, portanto, o sigilo só incidirá excepcionalmente. Visto que o “direito subjetivo das partes e advogados à intimidade somente estará garantido se não prejudicar o interesse publico a informação" ${ }^{13}$.

Dentro dessa lógica, para que se pratique o interrogatório por meio da videoconferência é possibilitado o acesso, no local da pratica de tal ato, para qualquer pessoa que queira assistir ao interrogatório ${ }^{14}$, de forma que não há de se falar de desrespeito à garantia

\footnotetext{
11 ÂMBITO JURÍDICO. A utilização da videoconferência no processo penal e seus principais aspectos processuais-constitucionais. Disponível em:<ambitojuridico.com.br/site/?n_link=revista_artigos_leitura\& artigo_id=11828>. Acesso em: 12 ago. 2018.

12 TÁvORA, Nestor; ALENCAR. Curso de Direito Processual Penal. 12. ed. Salvador: Editora JusPodivm, 2017. p. 83.

${ }^{13}$ LENZA, Pedro. Direito Constitucional Esquematizado. 16a ed.São Paulo: Saraiva, 2012. p. 1028.

${ }^{14}$ GROSSO, Eduardo Luís. A Necessidade do Sistema de Videoconferência no Processo Penal. Disponível em: ibccrim.org. br. Acesso em: 12 ago. 2018.
} 
da publicidade. Visto que, como já mencionado, os equipamentos permitem a transmissão audiovisual simultânea perfeitamente.

\section{DA LEGALIDADE DOS INTERROGATÓRIOS POR VIDEOCONFERÊNCIA}

\subsection{Constitucionalidade da regulamentação legal das audiências por videoconferência}

Antes da edição da já mencionada Lei 11900/2009, havia uma divergência acerca da permissão da utilização do instrumento tecnológico que permitia a realização da audiência com meio deste. Assim, os tribunais entendiam pelo seu não uso ante a ausência de previsão legal sob o argumento de que poderia haver um choque com garantias constitucionais. Prova disso, Rodrigo Carneiro Gomes cita como exemplo o julgamento do Supremo Tribunal Federal (STF) que atestou a inconstitucionalidade formal de uma lei de São Paulo que disciplinava a utilização da videoconferência ${ }^{15}$.

Após a regulamentação do tema, a discussão passou a ser sobre a constitucionalidade da referida lei. Nessa perspectiva, a parcela que pugna pela inconstitucionalidade utiliza os argumentos, já enfrentados por esse trabalho, que haveria violação a ampla defesa e a publicidade.

Por outro lado, este trabalho já expos que tais garantias não são descumpridas. Dissertando sobre a questão, Luiz Flavio Gomes argumenta que "a resistência à videoconferência (neste principio do século XXI) não poderia entrar para a história com mais volume e intensidade que a que gerou a máquina de escrever" ${ }^{16}$. Assim, tais argumentos contrários à utilização dessa ferramenta não devem prosperar, na medida em que não há de se falar em inconstitucionalidade de tal regulamentação ante a concretização dos princípios da ampla defesa e publicidade.

\subsection{Ampliações dos interrogatórios por videoconferência para réus presos}

Os benefícios da utilização dos recursos tecnológicos no judiciário foram expostos por este trabalho. Lopes, ao tratar do tema, aduz que "o Poder Judiciário não poderia ficar de fora,

15 GOMES, Rodrigo Carneiro. A LEI 11.900/2009 E A ADOÇÃO DA VIDEOCONFERÊNCIA NO BRASIL. Revista dos Tribunais, [S.L], v. 892, p. 403-424, fev. 2010.

${ }^{16}$ GOMES, Luiz Flávio. Videoconferência: Lei ${ }^{\circ}$ 11.900/2009. Revista Jus Navigandi, ISSN 1518-4862, Teresina, ano 14, n. 2028, 19 jan. 2009. Disponível em: <https://jus.com.br/artigos/12227>. Acesso em: 12 ago. 2018. 
e passou a usufruir dos recursos que vinham sendo oferecidos por esta preciosidade, adotando tais engenhos tecnológicos para dar maior eficácia a suas prestanças" 17.

Desta feita, faz-se necessário ampliar a utilização da ferramenta videoconferência, de modo a robustecer a sua aplicação a fim de efetivar as garantias constitucionais, ao passo que corrobora para uma economia do erário, garante a ordem pública e a duração razoável do processo.

Para isso, é necessário aperfeiçoar a sua utilização através de investimentos para garantir acesso à internet, em uma velocidade apta a permitir uma boa conexão, em todas as varas criminais, bem como na sala do presidio que o preso ficará. Também é necessário investir em equipamentos de áudio-imagem que permitam uma boa transmissão, de modo a permitir que o réu assista toda a instrução.

Além disso, faz-se necessário que os servidores tenham conhecimento de como utilizar a ferramenta, na medida em que embora seja de fácil uso, muitas vezes o aparato tecnológico não é utilizado por desconhecimento do seu modo de operação.

Após um período de estabilidade quanto ao uso da ferramenta, defende-se a edição de lei para proporcionar hipóteses de utilização da videoconferência, em se tratando de réus que se encontram presos, mais flexíveis de modo que um simples acordo entre os interessados - MP e defesa - permitam a autorização por parte do juiz. Uma vez que já foi demonstrado o quão benéfico esse instrumento, além da medida se demonstrar como adequada e dentro da realidade da sociedade moderna ${ }^{18}$.

\section{CONCLUSÃO}

A utilização das ferramentas tecnológicas no campo do judiciário é uma questão que envolve um grande debate. No que diz respeito à utilização da videoconferência o embate foi mitigado com a edição da Lei 11.900/2009. Entretanto, o uso desse mecanismo se dar de forma excepcional, ou seja, quando incide uma das hipóteses previstas na lei.

Foi exposto que os princípios da duração razoável do processo, garantia da ordem publica e economicidade são robustecidos com a utilização da videoconferência para realização

${ }^{17}$ LOPES, Carolina Beatriz Olsen. A importância das novas tecnologias para a prática do Direito. Revista de Direito Empresarial, [S.L], v. 3, p. 449-474, mai./jun. 2014.

${ }^{18}$ LENZA, Pedro. Direito Constitucional Esquematizado. 16ª ed.São Paulo: Saraiva, 2012. p. 1026. 
do interrogatório de réus presos. Ao passo que tal mecanismo não fere as garantias de defesa do acusado, quais sejam: a ampla defesa e a publicidade.

Argumentou-se que a regulamentação legal da videoconferência é constitucional, ante a concretização das garantias constitucionais. Além de defender o aperfeiçoamento e, posterior, ampliação da utilização da videoconferência para realização de interrogatórios de réus presos com a flexibilização das hipóteses previstas na Lei 11.900/2009. 


\section{REFERÊNCIAS BIBLIOGRÁFICAS}

ALENCAR, Rosmar Antonni Rodrigues Cavalcanti. Informática jurídica e tecnologia no processo penal. Revista dos Tribunais, [S.L], v. 940, p. 283 - 306, fev. 2014.

ÂMBITO JURÍDICO. A utilização da videoconferência no processo penal e seus principais aspectos processuais-constitucionais. Disponível

em:<ambitojuridico.com.br/site/?n_link=revista_artigos_leitura\&artigo_id=11828>. Acesso em: 12 ago. 2018.

GOMES, Rodrigo Carneiro. A LEI 11.900/2009 E A ADOÇÃO DA VIDEOCONFERÊNCIA NO BRASIL. Revista dos Tribunais, [S.L], v. 892, p. 403-424, fev. 2010.

GOMES, Luiz Flávio. Videoconferência: Lei n 11.900/2009. Revista Jus Navigandi, ISSN 1518-4862, Teresina, ano 14, n. 2028, 19 jan. 2009. Disponível em:

<https://jus.com.br/artigos/12227>. Acesso em: 12 ago. 2018.

GROSSO, Eduardo Luis. A Necessidade do Sistema de Videoconferência no Processo Penal. Disponível em: ibccrim.org.br. Acesso em: 12 ago. 20018.

JUS BRASIL. Interrogatório por videoconferência. Disponível em: <flaviocardosooab.jusbrasil.com.br/artigos/112232345/interrogatorio-por-videoconferencia >. Acesso em: 12 ago. 2018.

LENZA, Pedro. Direito Constitucional Esquematizado. 17ªed.São Paulo: Saraiva, 2013.

LOPES JUNIOR, Aury. Direito processual penal. 11 a ed. São Paulo: Saraiva, 2014,

LOPES, Carolina Beatriz Olsen. A importância das novas tecnologias para a prática do Direito. Revista de Direito Empresarial, [S.L], v. 3, p. 449-474, mai./jun. 2014.

PAULO, Vicente; ALEXANDRINO, Marcelo. Direito Constitucional descomplicado. 14. ed. Rio de Janeiro: Forense; São Paulo: Método, 2015.

TÁVORA, Nestor; ALENCAR, Rosmar Rodrigues. Curso de Direito Processual Penal. 13. ed. Salvador: Editora JusPodivm, 2018. 
GT 2 


\title{
O CRIME DE IMPORTUNAÇ̃̃O SEXUAL: UMA ANÁLISE DO ARTIGO 215-A DO CÓDIGO PENAL, INCLUÍDO PELA LEI No 13.781/2018.
}

\author{
THE SEXUAL IMPORTER CRIME: an analysis of Article 215-A of the Penal Code, \\ included by Law n' 13.781 / 2018.
}

\author{
Elizângela Conde Arnaiz ${ }^{1}$ \\ Lara Marinne Vasconcelos de Melo
}

\begin{abstract}
RESUMO: O presente artigo tem o cariz de apresentar criticamente a nova figura delitiva, prevista na Lei $\mathrm{n}^{\circ}$ 13.781/2018. Nos últimos anos surgiram casos que fizeram a sociedade geral e o judiciário entrarem num dilema: o caso em tela seria estupro ou mera contravenção penal? Tal matéria era discutida de forma equivocada, gerando revolta para a vítima e para a sociedade como um todo - o ato praticado não possuía todos os requisitos para ser enquadrado na tipificação de estupro, ao passo que também não seria apenas contravenção penal, por ferir a liberdade sexual da vítima e o princípio da dignidade da pessoa humana. Busca-se explanar através deste compêndio o avanço extraído do novo dispositivo, a partir da nova visualização dada a esses tipos penais, que outrora não eram valorados corretamente, gerando sensação de impunidade. Não se trata de corroborar com um pensamento punitivista, bastante comum na sociedade atual, mas de aplicar o Direito Penal conforme o princípio da proporcionalidade e razoabilidade. Pretende-se demonstrar tal tese argumentativa através do método indutivo, pois restará provado o impacto que tal instrumento legislativo terá, com exemplificações de situações reais e dados estatísticos, além de pilares doutrinários e jurisprudenciais. Para tanto, será utilizada metodologia bibliográfica e etnográfica corroborada à pesquisa de campo social, isto é, fatos do dia a dia da sociedade.
\end{abstract}

Palavras-Chave: Importunação Sexual; Estupro; Contravenção Penal; Dignidade Sexual.

\begin{abstract}
This article has the purpose of critically presenting the new criminal figure, foreseen in Law $n^{\circ} 13.781$ / 2018. In recent years there have been cases that have caused the general society and the judiciary to enter a dilemma: would the case be rape or merely a criminal offense? This matter was discussed in a wrong way, generating revolt for the victim and for society as a whole - the act performed did not have all the requirements to be included in the rape classification, whereas it would not be just a criminal offense, for injuring the victim. sexual freedom of the victim and the principle of human dignity. It seeks to explain through this compendium the progress extracted from the new device, from the new visualization given to these criminal types, which were not correctly valued in the past, generating a sense of impunity. It is not a matter of corroborating with a punitive thinking, quite common in today's society, but of applying Criminal Law according to the principle of proportionality and reasonableness. It is intended to demonstrate such an argumentative thesis through the inductive method, since the impact that such a legislative instrument will have will be proven, with examples of real situations and statistical data, in addition to doctrinal and jurisprudential
\end{abstract}

\footnotetext{
1 Estudante do curso de Direito do Centro Universitário Tiradentes/ AL - $6^{\circ}$ período.

2 Estudante do curso de Direito do Centro Universitário Tiradentes/ AL - $6^{\circ}$ período.
} 
pillars. For this purpose, a bibliographic and ethnographic methodology corroborated by social field research will be used, that is, facts from the daily life of society.

Key words: Sexual harassment; Rape; Criminal Misdemeanor; Sexual Dignity.

\section{INTRODUÇÃO}

A Importunação Sexual, embora seja uma Lei nova, é um fato bastante antigo e há muito vem sendo observado pela sociedade - e sofrido, principalmente, pelas mulheres. Os casos de maior repercussão aconteceram nos transportes públicos, como ônibus e metrô, tendo como vítimas mulheres que iam para seus trabalhos, faculdades, muitas vezes dormindo devido ao cansaço do dia. O que deveria ser um espaço privado, de domínio único e exclusivo de seus donos, o corpo humano passa a ser objetificado e utilizado para o prazer doentio alheio, que toca, masturba e até estupra através de uma falsa ideia de superioridade.

Por o Brasil ser ainda um país conservador, a cultura do machismo persiste, influenciando a forma de como a mulher é tratada no seu dia a dia. Nesse sentido, objetiva-se analisar o artigo 215-A do Código Penal, incluído pela Lei no 13.781/2018, que passou a tratar sobre a importunação sexual. Atualmente, situações de assédio serão punidas com prisão, o que antes acarretava apenas multa ao infrator, com total desproporcionalidade. Será objeto de estudo casos atuais e a cultura de estupro propriamente dita, evidenciando que o principal causador de crimes contra a dignidade sexual é o machismo enraizado na sociedade brasileira.

Através desta mudança significativa, é importante salientar que trata-se de um avanço no Direito Penal, não por agradar uma sociedade punitivista, mas por legitimar a Constituição Federal e estar em conformidade com seus princípios, como o da dignidade da pessoa humana e o da liberdade sexual. O Supremo Tribunal Federal colocava todos os atos libidinosos na mesma esfera, um beijo roubado poderia ser considerado semelhante a uma conjunção carnal forçada, a nova Lei vem também para diferenciar essas situações.

Trata-se de alcançar os objetivos explicitados através da metodologia indutiva, a qual será vista a partir dos dados bibliográficos colhidos da pesquisa de campo e etnográfica, fazendo com que o leitor crie um reflexo crítico, decorrente do estudo produzido neste artigo, de forma 
implícita, pois será possível explanar a opinião textual presente por intermédio de citações indiretas e críticas subentendidas.

\section{DOS CRIMES CONTRA A DIGNIDADE SEXUAL}

\subsection{O que são crimes sexuais segundo o direito penal?}

Após o desenvolvimento da teoria dos direitos humanos, a expressão do Código Penal (Lei 2.848/1940) “Crimes contra os Costumes”, título VI, não condizia com a realidade do século XXI, pois o Direito se desenvolve de acordo com a evolução social. Por isso, fez-se necessário modificar a Codificação para que não fosse mais taxada a forma de comportamento sexual do ser humano e sim salvaguardada a liberdade e dignidade individual, surgindo a substituição de tal título para "Crimes contra a Dignidade Sexual”.

O responsável por essa mudança foi o Decreto Lei 12.015/2009, tendo entrado em vigor dia 7 de Agosto de 2009, o qual tinha o objetivo de desmistificar o conservadorismo presente na legislação e ampliar o bem jurídico tutelado. Com isso, vê-se a valorização do princípio da dignidade da pessoa humana, previsto no art. $1^{\circ}$, III, da Constituição da República Federativa do Brasil ${ }^{3}$, através do desenvolvimento do princípio da isonomia, também exposto nesta Carta Magna (art. $5^{\circ}$, caput).

\subsection{A persistência do conservadorismo na sociedade brasileira}

Apesar das modificações já existentes no Direito Penal, a sociedade ainda apresenta um modo conservador de pensar e agir, visto que permanece preconceituosa, culpabilizando a vítima, seja por sua roupa, forma de se expressar, locais que frequenta, entre outros fatores. Convém destacar que, embora a moral sexual não seja mais o bem jurídico tutelado, a sociedade ainda a valora mais do que a dignidade e a liberdade sexual do indivíduo. Dessa forma, observase que houve a mudança legislativa, mas o meio social, de acordo com Muñoz Conde, não permite que a dignidade sexual seja merecedora desta tutela tal qual o costume. ${ }^{4}$

\footnotetext{
${ }^{3}$ BRASIL. Constituição da República Federativa do Brasil. Brasília, DF: Senado Federal, 1988.

${ }^{4}$ MUÑOZ CONDE, Francisco \& GARCÍA ARÁN, Mercedes.Derecho penal; Parte Geral, 1996, p. 206.
} 


\title{
2.3 Uma breve história do crime de importunação sexual
}

\author{
2.3.1 Análise do tipo penal
}

A importunação sexual, prevista no artigo 215-A do Código Penal, incluído pela Lei $\mathrm{n}^{\mathrm{o}}$ 13.781/2018, estabelece que "Praticar contra alguém e sem a sua anuência ato libidinoso com o objetivo de satisfazer a própria lascívia ou a de terceiro" ${ }^{\circ}$. Desse modo, constata-seque o supramencionado tipo penal é um crime pluriofensivo, isto é, protege mais de um bem jurídico: a liberdade sexual e a integridade corporal do cidadão.

De acordo com o Código Penal, a importunação sexual acontecerá quando houver a prática sem a anuência, ou seja, sem consentimento, mesmo que não ocorra contato físico entre os sujeitos. A criminalização da importunação sexual é importante para que não seja conferido um tratamento leve para situações de constrangimento e assédio ou para tutelar circunstâncias em que o constrangimento praticado não configura estupro ${ }^{6}$.

Isto posto, o tipo penal em estudo trata-se de crime comum, tanto no que se refere ao sujeito ativo como passivo, pois pode ser praticado ou sofrido por qualquer pessoa ${ }^{7}$. No que tange à modalidade da conduta delituosa, o referido artigo prevê apenas uma modalidade praticar -, e o elemento subjetivo é o dolo, caracterizado pela vontade consciente de praticar ato libidinoso com o fim de satisfazer a própria lascívia ou a de terceiro ${ }^{8}$.

\section{QUEM SÃO AS VÍTIMAS DOS CRIMES SEXUAIS?}

\subsection{Um olhar criminológico sobre a delinquência sexual}

\footnotetext{
${ }^{5}$ BRASIL. Código Penal. Editora Saraiva, Ed. 24, 15 de Janeiro de 2018.

${ }^{6}$ LIMA, Daniel; NETO, José Muniz..Estupro e gênero: evolução histórica e perspectivas futuras do tipo penal no Brasil. Canal Ciências Criminais, 2018a. Disponível em: <https://canalcienciascriminais.com.br/estuprogenero-brasil/>. Acesso em: 28 nov. 2018.

${ }^{7}$ CONSULTOR JURÍDICO. Anatomia do crime de importunação sexual tipificado na lei 13.718/2018. Disponível em: <https://www.conjur.com.br/2018-set-30/cezar-bitencourt-anatomia-crime-importunacaosexual>. Acesso em: 29 nov. 2018.

${ }^{8}$ Ibidem.
} 
Os crimes sexuais decorrem de outros tempos, permanecendo em todas as sociedades desde o desenvolvimento do ser humano. É possível notar tal fato, mesmo que não documentado, através da cultura machista que se perpetua, a qual começa a mostrar seu maior declínio neste século. Isso porque sempre há notícias acerca de crimes sexuais e, em muitos casos, também a forma cruel como se deram, o que leva os demais indivíduos a analisarem e a estereotiparem aquela situação, sendo praticamente inevitável não conjecturar determinadas características ao delinquente sexual.

Estuda-se que tais características não são constituídas de qualquer forma, mas sim adquiridas com a construção da personalidade do criminoso, dependendo de vários fatores íntimos e de perfil comportamental, fazendo parte disso classe econômica, etnia, religião, entre outros.

Antes a importunação sexual era vista apenas como crime moral, mas a inclusão legislativa já mencionada mostrou que é necessário enxergar os crimes sexuais de maneira mais profunda, para que não haja apenas a punição do indivíduo delinquente, mas principalmente uma conscientização da população acerca do assunto. Foi dado a ele o cognitivo de transgressão contra a dignidade sexual, o que atinge não só a liberdade de experiências e valores da vida sexual, mas também a visão de desprezo que em muitos momentos o agressor sente pela vítima, no quadro exposto principalmente à mulher, sendo tal questão relacionada à misoginia.

\subsection{Como o machismo cultural influencia para que a mulher seja a principal vítima}

O crime de importunação sexual pode ser considerado como uma das consequências do machismo cultural enraizado na sociedade, uma vez que as mulheres são as principais vítimas desse tipo penal. $\mathrm{O}$ fato de os homens demonstrarem um certo desprezo e sentimento de superioridade com relação a pessoas do sexo feminino é uma convicção ensinada pela sociedade que corrobora para esse quadro de violência.

Nesse sentido, os dados colhidos na pesquisa desenvolvida pelo IPEA (Instituto de Pesquisa Econômica Aplicada) demonstram com propriedade o patriarcalismo arraigado na sociedade brasileira visto que os crimes contra a dignidade sexual são crimes majoritariamente contra o gênero feminino, muito embora existam casos, estatisticamente menores, onde a vítima 
é homem ${ }^{9}$. Essa pesquisa trouxe à tona dados alarmantes referentes ao percentual de estupros que acometem pessoas do sexo feminino chegando a 89\% das vítimas (dados de 2011 do Sistema de Informações de Agravo de Notificação do Ministério da Saúde).

Diante disso, é notório que apesar dos esforços, como a criação da Lei Maria da Penha e da modificação na tipificação do Código Penal, é necessário que as atenções sejam voltadas não para medidas paliativas e sim na modificação da sociedade a fim de findar a objetificação da figura feminina.

\subsection{A ação penal nos crimes contra a dignidade sexual}

A ação penal é o direito que todo cidadão tem de convocar o Poder Judiciário para a resolução de lide na esfera criminal. Nesse sentido, as ações penais se dividem em três tipos: Ação Penal Pública Incondicionada, Ação Penal Pública Condicionada à Representação e, por fim, Ação Penal Privada. Em relação aos crimes contra a dignidade sexual, antes da Lei 12.015/2009 entrar em vigor, a ação penal era privada, com exceções previstas no antigo artigo 225 do Código Penal ${ }^{10}$ :

Art. 225 - Nos crimes definidos nos capítulos anteriores, somente se procede mediante queixa.

$\S 1^{\circ}$ - Procede-se, entretanto, mediante ação pública:

I - se a vítima ou seus pais não podem prover às despesas do processo, sem privar-se de recursos indispensáveis à manutenção própria ou da família;

II - se o crime é cometido com abuso do pátrio poder, ou da qualidade de padrasto, tutor ou curador.

$\S 2^{\circ}$ - No caso do $n^{\circ}$ I do parágrafo anterior, a ação do Ministério Público depende de representação.

Além dessas exceções, a Súmula 608 do Supremo Tribunal Federal (STF) traz outra possibilidade da ação ser pública incondicionada, em que o estupro é cometido mediante violência real ${ }^{11}$. Para os crimes praticados antes do advento da supramencionada lei, o Código Penal tinha como objetivo evitar o strepitusjudicii, isto é, dificultar a disseminação de

\footnotetext{
${ }^{9}$ PEIXOTO, A.; NOBRE, B. A responsabilização da mulher vítima de estupro. Revista Transgressões, v. 3, n.1, p 227-239, 27 maio 2015.

${ }^{10}$ BRASIL. Código Penal. Editora Saraiva, Ed. 24, 15 de Janeiro de 2018

${ }^{11}$ BRASIL. Supremo Tribunal Federal. Súmula $n^{\circ}$ 608. No crime de estupro, praticado mediante violência real, a ação penal é pública incondicionada. Julgado em 17/10/1984, DJ 31/10/1984.
} 
comentários que afetariam a honra da vítima. Contudo, o crime de importunação sexual é grave e existe interesse público pela segurança dos demais, além disso, pode ser considerado um problema de saúde pública, fazendo com que a antiga legislação provocasse discordância entre os doutrinadores, de modo que foi necessária uma reforma no ordenamento jurídico.

Isto posto, a ação dos crimes contra a dignidade sexual (nova nomeação), em regra, passou a ser pública condicionada à representação. Desse modo, nos termos da nova redação do art. 255 do Código Penal: “Art. 225. Nos crimes definidos nos Capítulos I e II deste Título, procede-se mediante ação penal pública condicionada à representação. (Redação dada pela Lei $n^{\circ} 12.015$, de 2009)"12. Excepcionalmente, a ação será pública incondicionada quando a vítima for menor de 18 anos ou pessoa vulnerável, previsto no parágrafo único do supramencionado artigo. ${ }^{13}$ Neste caso, as pessoas vulneráveis são os menores de 14 anos, os que por enfermidade ou deficiência mental não tem discernimento para praticar ato sexual e aqueles que não podem oferecer resistência.

Ademais, a Súmula 608 do STF ainda se encontra em plena eficácia, logo, a ação será incondicionada quando houver violência real. De acordo com o STF, a violência real é conceituada quando o autor utilizar de força física ${ }^{14}$ :

[...] Caracteriza-se a violência real não apenas nas situações em que se verificam lesões corporais, mas sempre que é empregada força física contra a vítima, cerceando-lhe a liberdade de agir, segundo a sua vontade. 2. Demonstrado o uso de força física para contrapor-se à resistência da vítima, resta evidenciado o emprego de violência real. Hipótese de ação pública incondicionada [...]

Por conseguinte, não existe mais a possibilidade da ação ser privada nestes casos, assim, sendo a vítima maior de 18 anos e capaz tem o direito de escolha e pode não representar, contudo se o faz caberá ao Ministério Público agir, sendo impedido de desistência em virtude dos princípios da indisponibilidade e obrigatoriedade.

\section{MACHISMO ENRAIZADO: CONSEQUÊNCIAS PARA A VÍTIMA}

\subsection{Consequências na saúde mental}

\footnotetext{
${ }^{12}$ BRASIL. Código Penal. Editora Saraiva, Ed. 24, 15 de Janeiro de 2018

${ }^{13}$ Ibidem.

${ }^{14}$ STF. Aplicação das súmulas no STF.
} 
De acordo com a Organização Mundial de Saúde - OMS, a violência sexual causa sérios problemas para a saúde sexual, física, mental e reprodutiva e levam a altos custos sociais e econômicos, além de haver os casos em que ocorre o suicídio ou o homicídio ${ }^{15}$.

Essas formas de violência podem levar à depressão, estresse pós-traumático e outros transtornos de ansiedade, dificuldades de sono, transtornos alimentares e tentativas de suicídio. Entre os efeitos para a saúde também estão dores de cabeça, dor nas costas, dor abdominal, fibromialgia, distúrbios gastrointestinais, mobilidade limitada e problemas de saúde em geral. ${ }^{16}$

\section{2 $O$ constrangimento que o processo causa às vítimas: impunidade versus exposição}

A violação do corpo são experiências que deixam traumas na vida e na saúde das pessoas que a vivenciam ${ }^{17}$, assim, é extremamente importante que estas vítimas recebam um tratamento diferenciado pelo Estado e pelos outros indivíduos. Isto porque, como visto no decorrer do artigo, a sociedade coloca como culpada a própria vítima, gerando medo e insegurança na mesma ao fazer a denúncia contra seu agressor.

Desse modo, a impunidade começa antes mesmo de o crime chegar à Justiça, visto que o mau atendimento a vítima impede que a mesma denuncie ${ }^{18}$. De acordo com a pesquisa feita pelo Fórum Brasileiro de Segurança Pública, nove em cada dez queixas foi contra o serviço de atendimento da Polícia Militar, assistência prestada em delegacias tradicionais e, também, especializadas $^{19}$.

Diante disso, é notável a falta de empatia e de preparação dos policiais com as vítimas de abuso sexual, ademais, o impregnado machismo na nossa sociedade causa mais julgamento moral para aquelas que se expõem. Se a não exposição causa impunidade, a exposição também

15 ORGANIZAÇÃO PAN-AMERICANA DA SAÚDE/ORGANIZAÇÃO MUNDIAL DE SAÚDE. Folha informativa - Violência contra as mulheres. Nov. 2017.

${ }^{16}$ ORGANIZAÇÃO PAN-AMERICANA DA SAÚDE/ORGANIZAÇÃO MUNDIAL DE SAÚDE. Folha informativa - Violência contra as mulheres. Nov. 2017.

${ }^{17}$ SUDÁRIO, S., ALMEIDA, P.C \& Jorge, M.S.B. Mulheres Vítimas de Estupro: Contexto e Enfrentamento dessa Realidade. Psicologia \& Sociedade, 17 (3), 73-79; set/dez: 24/11/2005.

${ }^{18}$ CART A CAPITAL. Parte da impunidade no crime sexual começa antes de chegar à justiça. Disponível em: <https://www.cartacapital.com.br/sociedade/parte-impunidade-no-crime-sexual-comeca-antes-de-chegar-ajustica>. Acesso em: 14 dez. 2018.

${ }^{19}$ SEGURANÇA PÚBLICA, Fórum B. Percepção sobre violência sexual e atendimento a mulheres vítimas nas instituições policiais. Fórum B. de Segurança Pública, set. 2016. 
não pune o infrator, pois é fato que há uma enorme dificuldade de reunir provas concretas do não consentimento, além de que nos procedimentos legais existe o risco da revitimização, em que a vítima tem seu corpo violado exposto causando mais humilhação e o sentimento de medo e convicção de que a polícia e o sistema não pode fazer nada ${ }^{20}$.

Portanto, é nítido que as instituições policiais e o ordenamento jurídico brasileiro são déficit quando se trata da violência sexual, havendo ainda empecilhos que dificultam o auxílio às vítimas e estas se sentem abandonadas e culpabilizadas, pois a todo custo devem comprovar que o que estão falando é verdade, tornando o processo ainda mais humilhante.

\subsection{Estudo de casos}

Os casos reais mostram que o machismo cultural persiste, pois muitos agentes que praticam o delito são do sexo masculino e acreditam, em sua maioria, que a mulher pode ser submetida ao seu assédio, prevalecendo, infelizmente, o sentimento de patriarcalismo conservador. As situações ilustrativas mais comuns são de práticas de atos libidinosos por homens contra mulheres em transportes públicos, estando muitas delas, em alguns dos casos, dormindo, o que revolta ainda mais uma parte da população que se preocupa, visto que há pessoas que ainda conseguem achar tal comportamento normal.

A Capital que mais noticia fatos desse tipo é São Paulo, sendo as situações flagradas em diferentes horários do dia e com agentes de estereótipos também distintos, não sendo possível dar a eles um denominador comum até o momento, pois também agem de maneiras diferentes e é necessária uma pesquisa para tanto. Em decorrência do novo tipo penal, é importante notar que muitos casos que chegaram às delegacias após ele já foram caracterizados como o crime em tela, o que, ainda em pequeníssima porcentagem, já mostra a grande incidência de casos.

Tais fatos estão nos mais diversos sites jornalísticos de notícias, mas muitos destes insistem em tratar a mulher como objeto ou até mesmo como culpada da situação, com manchetes como "Mulher reage e agride homem que estaria se masturbando dentro de ônibus", esta feita pelo site Tudo na Hora, do Estado de Alagoas, em decorrência de uma agressão sofrida 
por um jovem estudante à caminho da Universidade na Capital de Maceió, a qual foi constrangida por um homem se masturbando olhando para ela. ${ }^{21}$

\section{CONCLUSÃO}

É possível identificar que o machismo influencia diretamente o quadro atual das vítimas do crime de importunação sexual - não apenas este, mas todo o rol de crimes sexuais. O patriarcalismo enraizado na sociedade causa não apenas uma verticalização na escolha da vítima como também a forma que ela será observada pela sociedade, causando uma carência no que tange a assistência à vítima dos crimes sexuais. Esse olhar de julgamento diante desse grupo corrobora tanto para a impunidade, quanto para danos psicológicos irreparáveis. A vítima sofre não apenas por ser sujeito passivo de um crime, mas colhe devido a este diversas mazelas, como a sua culpabilização.

Nesse sentido, é notório que está entranhada na sociedade uma tendência a culpabilizar a vítima dos crimes sexuais, seja pelas vestes ou pelo comportamento da mulher no sentido de ser considerado, por essa parcela opressora, que, de certa forma, a vítima provocou o agressor ou mereceu o crime. Logo, apesar de avanços consideráveis em temas relacionados à mulher, é evidente que os valores arcaicos a colocam como uma figura submissa aos homens, provocando uma objetificação de seu corpo. O homem, por se sentir superior e detentor de todo o poder, acredita ter domínio do corpo feminino e o explora mesmo sem qualquer consentimento.

A partir disso, nota-se ser imprescindível a nova criação legislativa, já que esta vem para somar a um vasto rol de crimes já estipulados os quais não supriam a necessidade demandada do delito em tela. Tal tipificação criminal preenche uma lacuna tanto no quesito qualidade quanto em quantidade, pois há a prevalência da proporcionalidade e da razoabilidade, visto que há uma nova forma de enxergar os casos e, consequentemente, uma maneira mais equilibrada de puni-los.

Por conseguinte, ao identificar as motivações para esse quadro em que a mulher é vista pela sociedade bem como ao tratamento a que é submetida, é inegável que para se auferir uma mudança será exigido também um esforço coletivo. Por isso, é mister que sejam elencadas como

\footnotetext{
${ }^{21}$ REDAÇÃO TNH1. Mulher reage e agride homem que estaria se masturbando dentro de ônibus. Disponível em: $\quad$ https://www.tnh1.com.br/noticia/nid/video-mulher-reage-e-agride-homem-que-estaria-se-masturbandodentro-de-onibus/>. Acessoem: $26 \mathrm{dez} .2018$.
} 
prioridade políticas públicas que tenham o objetivo de conscientizar as pessoas da importância da superação do patriarcalismo, através da exigência de inclusão nas escolas, empresas e universidades pautas sobre as consequências do machismo, seja através de propagandas, palestras ou até mesmo aulas sobre o assunto. Somado a isso, uma proposta a longo prazo seria o ensino familiar, bem como escolar, de questões relacionadas ao gênero, principalmente no que diz respeito à igualdade, para criar homens e mulheres que se enxergam como semelhantes, aprendendo sobre convivência e respeito.

Além disso, é de suma importância que o acompanhamento das mulheres que sofreram crimes sexuais, como o crime de importunação sexual, seja feito em delegacias especializadas e com tratamento humanizado desde o primeiro contato até o acompanhamento psicológico da vítima. Nessa perspectiva, a inserção de mais psicólogos e assistentes sociais é uma maneira de incentivar a denúncia, bem como ajudar a vítima, para que ela tenha todo o tipo de apoio necessário e não sinta medo ao pensar em denunciar. Por fim, como já dito anteriormente, é imprescindível o investimento na educação de base, nas escolas e nos próprios lares, para que seja rompida essa idéia de seres superiores, para que crianças se tornem adultos conscientes, que respeitam o outro, rompendo com a cultura patriarcal que passa de geração em geração. 


\section{REFERÊNCIAS BIBLIOGRÁFICAS}

BRASIL. Código Penal. Editora Saraiva, Ed. 24, 15 de Janeiro de 2018.

BRASIL. Constituição da República Federativa do Brasil. Brasília, DF: Senado Federal, 1988.

BRASIL. Supremo Tribunal Federal. Súmula 608. No crime de estupro, praticado mediante violência real, a ação penal é pública incondicionada. Julgado em 17/10/1984, DJ 31/10/1984. Disponível em:

<http://www.stf.jus.br/portal/jurisprudencia/menuSumarioSumulas.asp?sumula=2694>.

Acesso em: 14 dez. 2018.

CARTA CAPITAL. Parte da impunidade no crime sexual começa antes de chegar à justiça. Disponível em: <https://www.cartacapital.com.br/sociedade/parte-impunidade-nocrime-sexual-comeca-antes-de-chegar-a-justica>. Acesso em: 14 dez. 2018.

CONSULTOR JURÍDICO. Anatomia do crime de importunação sexual tipificado na lei 13.718/2018. Disponível em: <https://www.conjur.com.br/2018-set-30/cezar-bitencourtanatomia-crime-importunacao-sexual>. Acesso em: 29 nov. 2018.

LIMA, Daniel; NETO, José Muniz..Estupro e gênero: evolução histórica e perspectivas futuras do tipo penal no Brasil. Canal Ciências Criminais, 2018a. Disponível em: $<$ https://canalcienciascriminais.com.br/estupro-genero-brasil/> Acesso em: 28 nov. 2018. MUÑOZ CONDE, Francisco \& GARCÍA ARÁN, Mercedes.Derecho penal; Parte Geral. 3 ed. Valencia, Tirant lo Blanch, 1996.

ORGANIZAÇÃO PAN-AMERICANA DA SAÚDE/ORGANIZAÇÃO MUNDIAL DE SAÚDE. Folha informativa - Violência contra as mulheres. Disponível em: $<$ https://www.paho.org/bra/index.php?option=com_content\&view=article\&id=5669:folhainformativa-violencia-contra-as-mulheres\&Itemid=820>. Acesso em: 27 ago. 2018.

PEIXOTO, A.; NOBRE, B. A responsabilização da mulher vítima de estupro. Revista Transgressões, v. 3, n.1, p 227-239, 27 maio 2015.

REDAÇÃO TNH1. Mulher reage e agride homem que estaria se masturbando dentro de ônibus. Disponível em: <https://www.tnh1.com.br/noticia/nid/video-mulher-reage-e-agridehomem-que-estaria-se-masturbando-dentro-de-onibus/>. Acesso em: $26 \mathrm{dez} .2018$.

STF. Aplicação das súmulas no stf. Disponível em: <http://www.stf.jus.br/portal/jurisprudencia/menusumariosumulas.asp?sumula=2694>. Acesso em: 01 set. 2018.

SUDÁRIO, S., ALMEIDA, P.C \& Jorge, M.S.B. Mulheres Vítimas de Estupro: Contexto e Enfrentamento dessa Realidade. Psicologia \& Sociedade, 17 (3), 73-79; set/dez: 24/11/2005.

WESTMARLAND, Nicole. Criminologias alternativas: a violência contra as mulheres. Porto Alegre: Editora Canal CiênciasCriminais, 2017. p 381-397. 
GT 3 


\title{
A DESUMANIZAÇÃO CARCERÁRIA COMO CAUSA DA INEFICÁCIA DA PENA
}

\author{
THE CARCERARY DESUMANIZATION AS A CAUSE OF THE \\ INEFFICIENCY OF THE SENTENCE
}

\author{
Amanda Assis Ferreira ${ }^{1}$ \\ Camila Christina Trancoso Goes ${ }^{2}$
}

\begin{abstract}
RESUMO: Este artigo objetiva analisar a problemática que envolve a desumanização dos presídios brasileiros como uma barreira para o alcance da eficácia das funções da pena, partindo de uma análise histórica da pena e da origem do cárcere e do direito de punir. Depois de breves considerações sobre a contextualização histórica, busca-se averiguar as causas que dão razão à essa desumanização e possíveis meios de realizar melhorias em um sistema tão caótico, sempre objetivando a eficácia da pena. Em que pese a dificuldade de resolução do problema, tem-se, por fim, sugestões de superação das dificuldades que permeiam o tema como a utilização de novas políticas públicas eficientes de curto prazo, o melhor aproveitamento da verbas públicas, a maior celeridade do judiciário, o oferecimento de personalidade à pena, a disponibilização de agentes carcerários mais preparados e respeito em geral às garantidas previstas aos encarcerados.
\end{abstract}

Palavras-chave: Pena; ineficácia; prisão; punir

\begin{abstract}
This article aims to analyze the problem of dehumanizing brazilian prisons as a barrier to the effectiveness functions of the sentence, starting with a historical analysis of the sentence and the origin of the prison and the right to punish. After brief considerations about historical contextualization, it is sought to ascertain the causes that give reason to this dehumanization and possible means to realize improvements in a chaotic system, always objectifying the effectiveness of the sentence. Although the difficulty of solving the problem, we have, at last, suggestions for overcoming the difficulties that permeate the theme as the use of new efficient public policies in the short term, better use of public funds, speeding up of the judiciary, offering personalities to the sentence, availability of prison officers more prepared and generally respecting the guarantees provided for those incarcerated.
\end{abstract}

Keywords: sentence; effectiveness; prision; punish

\section{INTRODUÇÃO}

\footnotetext{
${ }^{1}$ Graduanda no Centro Universitário Tiradentes - UNIT/AL. E-mail: amandaassisfz@ hotmail.com

${ }^{2}$ Graduanda no Centro Universitário Tiradentes - UNIT/AL. E-mail: camilagoes_@ hotmail.com
} 
O surgimento do Direito Penal foi concomitante ao surgimento da pena. Mesmo que tenha evoluído em relação à suas formas de aplicação, a pena ainda hoje se configura como uma sanção jurídica derivada de uma infração penal, como uma resposta à sociedade que tem seus bens jurídicos lesados pelo delito cometido.

O sistema penitenciário brasileiro, como muito abordado pela mídia, está em rápido processo de deterioração. Por outro lado, a maioria da população, guiada por um senso de vingança descabido, apoia o aprisionamento sem se importar com as condições impostas aos infratores. Tais condições se apresentam desde a estrutura deplorável dos presídios até a falta de humanidade com o qual os encarcerados são tratados: celas insalubres, violência cotidiana, falta de individualidade na pena que por sua vez desencadeia a chamada "infecção criminal".

Dessa forma, o Estado, suposto garantidor de cumprimentos legais, ignora veementemente os direitos dos presos, presentes em vários artigos do Código Penal, da Constituição e da própria Lei de Execução Penal, criada exatamente com o intuito de regularizar esta situação.

O Instituto de Pesquisa Econômica Aplicada (IPEA) a pedido do Conselho Nacional de Justiça (CNJ) avaliou a questão da reincidência e aponta que esta girava em torno de 24,4\% (em cada quatro ex-detentos) em até cinco anos após a obtenção de liberdade ${ }^{3}$. Assim, é evidente a dificuldade do Estado em realizar a reinserção do infrator na sociedade.

Todos esses pontos somados comprometem o objetivo real da pena: punir ao mesmo tempo em que ressocializa, acarretando consequências sociais, econômicas, jurídicas e políticas sobre toda uma sociedade que já não consegue mais conviver com o medo. Por fim, o presente artigo tem sua construção baseada em pesquisas bibliográficas, artigos científicos e livros publicados por especialistas na área e objetiva analisar a problemática que envolve a desumanização dos presídios brasileiros como uma barreira para o alcance da eficácia das funções da pena.

\footnotetext{
${ }^{3}$ BRASIL. CONSELHO NACIONAL DE JUSTIÇA. Um em cada quatro condenados reincide no crime, aponta pesquisa. Disponível em: <cnj.jus.br/noticias/cnj/79883-um-em-cada-quatro-condenadosreincide-no-crime-aponta-pesquisa>. Acesso em: 21 ago. 2018.
} 


\section{DESENVOLVIMENTO}

\subsection{Origem do direito de punir: $O$ nascimento da prisão}

Apesar de muitos estudos haverem sobre o tema do nascimento da prisão, o filósofo Michel Foucault em seu livro "Vigiar e Punir"4 apresenta uma genealogia da punição e das prisões, não somente preocupando com a origem propriamente dita do sistema punitivo, mas de uma forma que pudesse entender os limites entre processos e mudanças ocorridas neste sistema e como esse mesmo sistema foi se reformulando com o passar do tempo.

Os sistemas prisionais tiveram origem no século XVIII. Durante o processo de evolução das penas três sistemas penitenciários obtiveram destaque: o Pensilvânico, o Alburniano e o Progressivo. Os delinquentes já haviam sofrido severas torturas a seu corpo físico, por isso, como aduz Rogério Greco: "Podemos dizer que a pena de prisão, ou seja, a privação de liberdade como pena principal, foi um avanço na triste história das penas"

O sistema Pensilvânico, também conhecido como sistema Filadélfia e Celular foi iniciado em 1790 na Walnut Street Jail. Foi caracterizado pelo recolhimento em celas, isolamento em relação a outros condenados, proibição do trabalho e de visitas, além disso, visava o arrependimento mediante a leitura da Bíblia. Recebeu diversas críticas em razão de ser considerado demasiadamente severo, impossibilitando a reinserção do condenado na sociedade. ${ }^{6}$

Embasado nas críticas ao sistema anterior foi criado o sistema Alburniano ou Silent System, de rigor moderado em relação ao Pensilvânico. Teve início em 1818 e caracterizava-se pela permissão para trabalho (primeiramente em suas próprias celas e posteriormente em grupo), isolamento noturno, silêncio absoluto entre os presos, proibição de visitas e indiferença em relação à instrução e aprendizado dos presos ${ }^{7}$. Falhas nesse sistema foram apontadas por Manoel Pedro Pimentel:

\footnotetext{
${ }^{4}$ FOUCAULT, Michel. Vigiar e punir: nascimento da prisão. 42 ${ }^{\mathrm{a}}$ ed. Petrópolis: Editora Vozes, 2014, P.36

${ }^{5}$ GRECO, Rogerio. Curso de direito penal: parte geral. 14 ed. Rio de janeiro: Impetus, 2014. P.485

${ }^{6}$ Ibidem.

${ }^{7}$ GRECO, Rogerio. Curso de direito penal: parte geral. 14 ed. Rio de janeiro: Impetus, 2014. P.487
} 
O ponto vulnerável desse sistema era a regra desumana do silêncio. [...] falhava também o sistema pela proibição de visitas, mesmo dos familiares, com a abolição do lazer e dos exercícios físicos, bem como uma notória indiferença à instrução e ao aprendizado ministrado aos $\operatorname{presos}^{8}$

Na sequência surgiu o sistema Progressivo, primeiramente na Inglaterra, século XIX, e depois na Irlanda. Caracterizou-se de forma diferente em cada país. Na Inglaterra, foi organizado em 3 (três) fases: isolamento absoluto do preso; trabalho grupal, silêncio absoluto e isolamento noturno; por fim, livramento condicional. Na Irlanda teve 4 (quatro) fases: a segregação absoluta; isolamento noturno, convivência grupal diurnamente e silêncio absoluto; prisão intermediária, tendo local de cumprimento de pena diferenciado; por último, a liberdade condicional. ${ }^{9}$

O Brasil adere ao sistema Progressivo aos moldes brasileiros como caminho para atingir a eficácia da pena, porém a realidade não condiz com o disposto na lei, essencialmente na Lei de Execução Penal (Lei no 7.210, de 11 de julho de 1984) ${ }^{10}$, o que implica diretamente no alcance desta eficácia.

A prisão, surgida como um instrumento de substituição para as torturas e penas de morte, atualmente muito se assemelha a estas. A partir da falta de saneamento básico, superlotação carcerária, ociosidade dos presos, crescimento das facções criminosas dentro das unidades prisionais, além de outros fatores, colaboram para que o sistema penitenciário brasileiro vivencie o caos que hoje é. Tais fatores vão de encontro à dignidade da pessoa humana e transformam os presídios em lugares desumanos.

A omissão do Estado e da sociedade deixa de lado o fato de que as finalidades da pena não estão sendo atingidas e que a sociedade, no futuro, receberá novamente em seu convívio os presos que tiveram seus corpos violados e sua dignidade deixada de lado.

Em coadunação com Greco, "a pena deve reprovar o mal produzido pela conduta praticada pelo agente, bem como prevenir futuras infrações penais" ${ }^{11}$. Dessa forma, as finalidades da pena consistem na reprovação de um crime que foi cometido, bem como

\footnotetext{
${ }^{8}$ PIMENTEL, Manoel Pedro. Do crime continuado. ed., São Paulo: Editora Revista dos Tribunais, 2001, P.137

${ }^{9}$ GRECO, Rogerio. Curso de direito penal: parte geral. 14 ed. Rio de janeiro: Impetus, 2014. P.489

10 BRASIL. Lei de execução penal. Lei $n^{\circ} 7210$ de 11 de julho de 1984. Disponível em: <http://www.planalto.gov.br/ccivil_03/LEIS/L7210.htm >. Acesso em: 01/09/2018

${ }^{11}$ GRECO, Rogerio. Curso de direito penal: parte geral. 14 ed. Rio de janeiro: Impetus, 2014. P.489
} 
na prevenção de futuros atos ilícitos e na ressocialização do delinquente. $\mathrm{O}$ atual sistema, no entanto, é ineficaz no tocante à prevenção e ressocialização, visto que o número de presos reincidentes cresce na realidade brasileira.

Torna-se urgente a necessidade de que os presídios passem por modificações, tanto em suas estruturas, para que consigam suprir a demanda, como também na forma de vivência dos que ali estão, par Lei de Execuções Penais a que as finalidades da pena atinjam sua eficácia. Não se pode esperar seres humanos melhores, reeducados, se estes são inseridos em lugares que colaboram para a sua degradação e não para a sua melhora.

\subsection{A atuação do Estado em relação ao cumprimento dos objetivos da pena}

Os objetivos da pena não conseguem ser alcançados pelas péssimas condições de nossas penitenciárias e a situação gera uma visão pessimista sobre a efetividade e objetividade da pena. Logo, o Estado como detentor legal do uso da força perde-se ao não administrar tal poder devidamente nem seu papel de garantir os direitos humanos.

De acordo com dados de junho de 2016 do Levantamento Nacional de Informações Penitenciárias, que é um programa criado pelo Departamento Penitenciário Nacional, a população carcerária brasileira já era a terceira maior do mundo, possuindo um total de 726.712, enquanto o número de vagas era de apenas $368.049^{12}$. Visto isso, a Lei de Execução Penal há tempos é desrespeitada e ignorada, sendo assim, a pena e suas garantias não são cumpridas e os aprisionados sofrem com a falta de condições básicas de sobrevivência e a relativização de seus direitos humanos.

Paralelamente a isso, necessita-se entender como são administrados os centros de detenção brasileiros. Tais locais são responsabilidade dos governos estatais, os quais tem autonomia de constituir diferentes estruturas penais, o que influencia diretamente as questões de variabilidade nos aspectos encontrados em suas locações e os investimentos realizados. Porém, o governo federal também possui autoridade para interferir na

12 AGÊNCIA BRASIL. Com 726 mil presos, brasil tem terceira maior população carcerária do mundo. Disponível em: <http://agenciabrasil.ebc.com.br/geral/noticia/2017-12/populacao-carceraria-dobrasil-sobe-de-622202-para-726712-pessoas>. Acesso em: 06 set. 2018. 
realidade apresentada por meio de três órgãos: o Ministério da Justiça, o Departamento Penitenciário e o Conselho Nacional de Política Criminal e Penitenciária.

\subsection{A atuação do Estado na teoria: garantias relacionadas aos direitos humanos e fundamentais dos detentos}

O Brasil segue a teoria mista da pena, logo, o Estado necessita seguir três pilares determinados por ela, que são a retribuição, a prevenção e a ressocialização. Ou seja, precisa garantir que o criminoso cumpra sua pena em condições humanas básicas de sobrevivência, como diz o Código Penal em seu artigo 38, que aduz que "O preso conserva todos os direitos não atingidos pela perda da liberdade, impondo-se a todas as autoridades o respeito à sua integridade física e moral". ${ }^{13}$

Ademais, a questão da humanização da pena ainda é encontrada no artigo $5^{\circ}$ da Constituição Federal em seu inciso XLIX, que institui a preservação da integridade física e moral do apenado ${ }^{14}$. Somado a isso, as penas privativas de liberdade estão regulamentadas no Código Penal do artigo 33 ao 42 e a fixação da pena é encontrada no artigo 59 que será seguindo pelo juiz. Porém, o Estado encontra barreiras para conseguir sair do plano teórico para o prático, principalmente, a sociedade que possui em suas bases ideológicas o estigma da condenação e da satisfação ao observar que a pena foi aplicada ${ }^{15}$. Tal pensamento é refletido pelo artigo 78 do Código Penal ${ }^{16}$ que declara a necessidade de observação dele para acompanhar o cumprimento de sua pena.

A Lei de Execução Penal Lei ${ }^{\circ}$ 7210/84, busca garantir os direitos dos aprisionados e internados, fundamentando as condições básicas de sobrevivência que são

\footnotetext{
13 BRASIL. Código de Processo penal. Decreto-Lei 2.848, de 07 de dezembro de 1940. Disponível em: http://www.planalto.gov.br/ccivil_03/decreto-lei/Del2848compilado.htm. Acesso em 04 de setembro de 2018.

14 BRASIL. Constituição (1988). Constituição da República Federativa do Brasil. Disponível em: http://www.planalto.gov.br/ccivil_03/constituicao/constituicaocompilado.htm. Acesso em 04 de agosto de 2018.

${ }^{15}$ BRASIL. Código de Processo penal. Decreto-Lei 2.848, de 07 de dezembro de 1940. Disponível em: http://www.planalto.gov.br/ccivil_03/decreto-lei/Del2848compilado.htm. Acesso em 04 de setembro de 2018.

${ }^{16}$ BRASIL. Código de Processo penal. Decreto-Lei 2.848, de 07 de dezembro de 1940. Disponível em: http://www.planalto.gov.br/ccivil_03/decreto-lei/Del2848compilado.htm. Acesso em 04 de setembro de 2018.
} 
obrigatórias e que almejam a ressocialização desses indivíduos ${ }^{17}$. Ela foi criada por conta da necessidade de normatizar a execução das penas e medidas privativas de liberdade. Logo, no artigo $5^{\circ}$ ela classifica e individualiza cada indivíduo segundo um exame da personalidade $^{18}$. Já em seu artigo $10^{\circ}$, determina que o Estado tem uma obrigação assistencial com os aprisionados ${ }^{19}$ e no artigo 22 adverte que ela ocorrerá com o intuito de que eles consigam retornar ao convívio social ${ }^{20}$.

No artigo 12 especifica a assistência material básica que deve ser oferecida ${ }^{21}$. Porém, como são objetos de difícil obtenção, cada local impreterivelmente terá um local de venda deles, cuja lei determina em seu artigo $13^{22}$. Em seguida, o artigo 14 assegura o auxílio médico e odontológico, o qual precisa ser acessível a todos os presos ${ }^{23}$. Nos artigos 15 e 16, está a assistência jurídica, pois a maioria deles não possuem condições financeiras para conseguir contratar um advogado ${ }^{24}$. Por conseguinte, dos artigos 17 ao 21 busca-se salvaguardar as condições educacionais necessárias, mas também, compromete-se a realizar um censo para avaliar a eficácia das medidas aplicadas ${ }^{25}$.

O artigo 24 garante a assistência religiosa, logo, torna a liberdade de cultos e missas são permitidas e indispensáveis para a ressocialização ${ }^{26}$. Por fim, vale ressaltar que os direitos dos presos estão estabelecidos a partir do artigo 40 até o 43 e os deveres no artigo $39^{27}$. Desse modo, a LEP tenta consolidar a questão humana da pena, a qual é essencial para diminuir a deplorável situação atual do sistema carcerário que tem como caraterísticas cotidianas a violência e o desrespeito aos direitos humanos.

\subsection{A atuação do Estado na prática}

17 BRASIL. Lei de execução penal. Lei $n^{\text {o }} 7210$ de 11 de julho de 1984. Disponível em: <http://www.planalto.gov.br/ccivil_03/LEIS/L7210.htm >. Acesso em: 01/09/2018

${ }^{18}$ Ibid

${ }^{19} \mathrm{Ibid}$

${ }^{20}$ Ibid

${ }^{21}$ Ibid

${ }^{22}$ Ibid

${ }^{23}$ Ibid

${ }^{24}$ Ibid

${ }^{25}$ Ibid

26 BRASIL. Lei de execução penal. Lei $n^{\circ} 7210$ de 11 de julho de 1984. Disponível em: <http://www.planalto.gov.br/ccivil_03/LEIS/L7210.htm >. Acesso em: 01/09/2018

${ }^{27}$ Ibid 
O Estado tem como papel assegurar os direitos das pessoas e a melhoria destes cada vez mais, o que não tem sido feito. No âmbito da prisão, são essenciais que sejam preservados os princípios básicos dos Direitos Humanos, como a dignidade da pessoa humana. Se as assistências necessárias fossem impostas nos presídios, a situação no qual eles se encontram seria totalmente diferente. A pena finalmente teria a função de ressocializar que até então só é vista na teoria, pois como já visto antes, o encarceramento na prática ajuda mais no aumento da criminalidade do que o contrário.

Com isso, é possível afirmar que o Estado é o responsável por esta má utilização dos presídios, pois deveria ser uma solução de casos mais graves, e atualmente, é a primeira solução para todos os casos, o que se dá a superlotação nos presídios. Assim, a criminalidade é uma das consequências dessa superlotação, visto que o Estado não está cumprindo com o que a Constituição e as leis determinam.

Diante disso, nota-se que a falta de estrutura das instituições é acarretada pela superlotação, mas também pela má administração dos recursos financeiros. Assim, a superlotação carcerária instiga a revolta dos aprisionados que veem rebeliões e motins como formas para conseguir atenção sobre este descaso o qual são submetidos, tanto dos governantes como da mídia para atingir o resto da sociedade.

Porém, sabe-se que esse desacaso faz-se velado por supostas garantias que são aplicadas. As prisões construídas e/ou administradas com parcerias público-privadas são excelente exemplo disso, tornando o suplício bem velado, sendo, afinal, nas palavras de Foucault "punições menos diretamente físicas, uma certa discrição na arte de fazer sofrer, um arranjo de sofrimentos mais sutis, mais velados, mais despojados de ostentação(... $)^{28, "}$

O cenário das prisões é caótico e desumano, porém a sociedade ainda crê que aprisionar é uma forma de fazer justiça, não se pensa no resultado que acarretará, nas modificações na personalidade do indivíduo aprisionado pelas condições a que será submetido. Não se pensa que tal indivíduo retornará ao convívio social com o estigma de condenado e com maior mágoa e insatisfação com o ordenamento social, então, é perceptível a perda da função da pena.

\footnotetext{
${ }^{28}$ FOUCAULT, Michel. Vigiar e punir: nascimento da prisão. 42a ed. Petrópolis: Editora Vozes, 2014,
} P.13 


\section{A PRECARIEDADE NO CÁRCERE COMO CONTRIBUTO PARA O NÃO ALCANCE DAS FINALIDADES DA PENA}

A problemática da atual situação da aplicação das penas no Brasil gira em torno do seu caráter ressocializador que pouco tem gerado efeito na realidade dos presos brasileiros. Somado a isso, a situação de abandono dos presídios que corroboram para a manutenção de uma sociedade carcerária cada vez maior, com índices elevados de crimes (dentro dos cárceres) e grandes taxas de reincidência. Vale salientar a carência dentro dos presídios que não atendem as necessidades básicas do homem, que são colocados em situações desumanas, com celas lotadas.

\subsection{Causas da ineficácia da pena}

$\mathrm{Na}$ teoria, o objetivo da pena privativa de liberdade é retirar o criminoso da sociedade, punindo-o pelo crime ocorrido, ao mesmo tempo em que o coloca numa realidade de ressocialização. No entanto, na prática, a teoria torna-se outra: presídios lotados que não atendem a necessidades básicas de um ser humano e pouco - ou nenhum - instrumento de ressocialização. Esta situação é um dos principais geradores de reincidência e faz com que o infrator saia ainda mais perigoso para a sociedade.

O encarceramento, surgido como instrumento para substituir as penas de morte e as torturas, não consegue, atualmente, ser eficaz e garantir o objetivo da pena. Muito embora tenha surgido de forma revolucionária, tornou-se um ambiente desumano que funciona como uma escola de aperfeiçoamento do crime, pois mistura indivíduos que cometeram diferentes delitos; transforma um "ladrão de galinha", por exemplo, em um grande traficante.

A tendência dessa realidade é perpetuar-se, visto que a superlotação carcerária é de conhecimento do poder público e da sociedade e, mesmo assim, nenhuma medida é realizada. Dessa forma, a população carcerária continua crescendo e poucos são os presídios que são construídos para atender a essa demanda, com espaços suficientes e sem afrontar aos direitos fundamentais do homem. 
Enquanto o sistema prisional brasileiro não possuir mecanismos que assegurem o objetivo principal das penas, como, por exemplo, a ressocialização, a realidade do cárcere continuará sendo representada por seu sucateamento e o reflexo será o mesmo: sua influência direta para a não aplicação eficaz da pena.

\subsection{A demonstração da ineficácia da pena pela reincidência criminosa}

Segundo dados do Instituto de Pesquisa Econômica Aplicada (IPEA) a pedido do Conselho Nacional de Justiça (CNJ), divulgado em 2015, 1 em cada 4 condenados reincidem no crime. Esse estudo se refere apenas à reincidência legal, que é aquela cometida nos cinco primeiros anos após o cumprimento da pena anterior ${ }^{29}$. O artigo 63 do Código Penal considera reincidência quando após transitar em julgado a sentença, o indivíduo cometer outro crime que já tenha sido condenado por outro crime anterior, no Brasil ou no estrangeiro. ${ }^{30}$

Muito embora a Lei de Execução Penal (LEP) estabeleça critérios para divisão de presos, seja por idade ou pelo tipo do crime, na prática essa divisão acaba por subexistir. Prova disso, tal fato é citado na entrevista presente no "Apêndice A" desse trabalho com Paulo Henrique Amorim de Miranda Guimarães Cabral, agente penitenciário do Presídio de Segurança Máxima em Maceió, como um dos motivos da não concretização da LEP.

Diante dessa inexistência de divisão, permite-se o contato entre criminosos de crimes dito mais graves com criminosos de crimes mais leves ou de presos provisórios com presos já condenados. Esse contato possibilita a chamada "infecção criminal" ou "faculdade do crime" como popularmente é conhecida, trata-se da troca de informações de indivíduos de alta para o de baixa periculosidade. Vale ressaltar que muitas vezes esses indivíduos ditos de baixo risco são criminosos por acaso, a exemplo daquele que furtou um supermercado para conseguir se alimentar.

\footnotetext{
${ }^{29}$ CONSELHO NACIONAL DE JUSTIÇA. Um em cada quatro condenados reincide no crime, aponta pesquisa. Disponível em: <cnj.jus.br/noticias/cnj/79883-um-em-cada-quatro-condenados-reincide-nocrime-aponta-pesquisa>. Acesso em: 05.09.2018.

${ }^{30}$ BRASIL. Código de Processo penal. Decreto-Lei 2.848, de 07 de dezembro de 1940. Disponível em: http://www.planalto.gov.br/ccivil_03/decreto-lei/Del2848compilado.htm. Acesso em 04 de setembro de 2018.
} 
Tal falta ocasiona a sujeição dos presos às regras do mundo crime, presente nos presídios, e a aprendizagem destas regras, na medida em que deve ser respeitada uma hierarquia. Assim, o indivíduo que cometeu algum delito de menor grau, na prisão encontra a ferramentas necessárias para se elevar de porte, ou seja, assim como em uma faculdade em que os estudantes, a priori, desconhecem a respeito do que vão se graduar, no final da graduação possuem um amplo conhecimento de uma área que desconheciam ou que conheciam superficialmente. E como em uma infecção em que agentes biológicos patógenos se multiplicas, na infecção criminal existe uma cadeia de troca de conhecimentos que se perpetua entre os presos, dificultando o caráter ressocializador da pena, o que se comprova com a reincidência criminal.

\section{AS CONSEQUÊNCIAS DA INEFICÁCIA DA PENA}

Percebe-se que não é por acaso que as consequências tão cruéis sejam levadas como normais pelo judiciário e pela sociedade. Cesare Beccaria em seu livro "Dos delitos e das penas" escreve que

É porque o sistema atual da jurisprudência criminal apresenta aos nossos espíritos a ideia da força e do poder, em lugar da justiça; é porque se lançam, insdistintamente, na mesma masmorra, o inocente suspeito e o criminoso convicto; é porque a prisão entre nós é antes um suplício que um meio de deter um acusado $(. . .)^{31}$

Como consequência do não atingimento das finalidades da pena está a reincidência criminal, tendo em vista que o caráter ressocializador da pena não foi alcançado. Ligado a este fato está o custo do preso para com o Estado, visto que os altos custos de manutenção do sistema penitenciário visam a "recuperação" do indivíduo para a sociedade e no momento em que o indivíduo reincide no crime, o Estado deverá investir novamente nessa reabilitação. Além disso, permite a já mencionada infecção criminal, possibilitando a transformação do criminoso ao sair da prisão no sentido de ser mais perigoso.

Outro fator relevante também ligado a reincidência criminal é a falta de postos de trabalhos oferecidos dentro da prisão que possibilitem uma função para o indivíduo

${ }^{31}$ BECCARIA, Cesare. Dos delitos e das penas. 2 ed. São Paulo: Edipro, 2015, P.30. 
quando do cumprimento da sua pena. Assim, no retorno para sociedade as pessoas encontram poucas oportunidades de emprego, devido à inexperiência de atuação em alguma área somada ao preconceito presente na população para com ex-presidiários.

Além desses fatos, possibilita o desrespeito à dignidade da pessoa humana ao não cumprir os requisitos elencados no artigo 88 da LEP, a exemplo do mínimo de seis metros quadrados da área da unidade celular individual ${ }^{32}$. Quando na realidade existe a superlotação dos presídios, já que os presos são colocados em celas com a sua capacidade muito acima do limite.

\subsection{Prender como uma resposta à sociedade}

O desejo da sociedade de punir alguém pelo delito cometido é culturalmente adquirido e gradativamente disseminado. $\mathrm{O}$ ser humano responde aos estímulos do meio em que vive, se algo o machuca, ele busca se defender, se o fazem mal, ele tenta revidar. É algo instintivo e que necessitou ser controlado para que a vida em sociedade não se tornasse um caos.

Assim, na Mesopotâmia (atual Iraque) foi desenvolvido o código de Hamurabi, um marco para o Direito Penal, nele contido a Lei do Talião que discorria acerca da punição proporcional ao crime cometido para que não ocorressem os excessos de violência. Após estes demais códigos foram desenvolvidos de acordo com os delitos cometidos em dado tempo e com o que sociedade da época exigia, sempre buscando punir os crimes cometidos e inibir a prática destes.

Hoje, apesar dos códigos e da Constituição versarem acerca dos direitos humanos tem-se, graças ao desenvolvimento das tecnologias, grande número de pessoas alienadas à mídia que são movidas por discursos de ódio totalmente contrários às leis, aguçando os instintos mais primitivos do homem e levando a sociedade ao retrocesso. Como a medida mais grave de punição admitida é o encarceramento, esta é a resposta esperada para a grande parcela da sociedade atual que é movida pelo ódio.

32 BRASIL. Lei de execução penal. Lei $n^{\circ} 7210$ de 11 de julho de 1984. Disponível em: <http://www.planalto.gov.br/ccivil_03/LEIS/L7210.htm >. Acesso em: 01/09/2018 


\section{CONCLUSÃO}

Considerando o que foi exposto no artigo e os demais aspectos políticos, econômicos, jurídicos e sociais que envolvem a questão na atualidade, evidencia-se a necessidade que toda uma sociedade ainda tem no aprisionamento e que este é necessário por ser uma resposta à angústia diária sofrida pelo problema da segurança pública.

Coadunando com o pensamento da autora Juliana Borges em seu livro "O que é encarceramento em massa?", temos que:

Muito do que entendemos hoje como Justiça Criminal tem influência do processo de transformações político-filosóficas e sociais que ocorreram a partir dos séculos XVIII e XIX. Anterior a isso, as punições eram estabelecidas por suplícios, ou seja, o exercício do poder marcado no corpo e uma política punitiva estabelecida pelo medo e flagelos. ${ }^{33}$

Assim, é evidente que a situação atual do sistema penitenciário é insustentável por haver falhas tanto em sua estrutura física quando em sua estrutura sistemática. Não obstante, a má utilização das verbas públicas, o pensamento retrógrado de focalizar a importância no punir e não no ressocializar e o descaso do Estado atrapalham diretamente na evolução do sistema carcerário que poderia ser melhorado através de novas políticas públicas eficientes de curto prazo, melhor aproveitamento da verba com disponibilização de atendimento psicológico, maior celeridade do judiciário, dar personalidade à pena, disponibilizar agentes carcerários mais preparados e respeito em geral às garantidas previstas aos encarcerados.

Sobre a perversidade do cárcere, Eugênio Raúl Zaffaroni adverte para o fato de que "a seletividade, a reprodução da violência, a criação de condições para maiores condutas lesivas, a corrupção institucionalizada, a concentração de poder, a verticalização social e a destruição das relações horizontais ou comunitárias" ${ }^{34}$ não configuram características conjunturais do exercício de poder de todos os sistemas penais, mas sim estruturais.

33 BORGES, Juliana. O que é: encarceramento em massa?. 1 ed. Belo Horizonte: Letramento: justificando, 2018, P.31.

${ }^{34}$ ZAFFARONI, Eugenio Raúl. Em Busca das Penas Perdidas: a perda de legitimidade do sistema penal. Trad. Vania Romano Pedrosa, Amir Lopez da Conceição. 5. ed. Rio de Janeiro: Revan, 2012. p. 15. 
Sendo assim, como sugestões adicionais de melhoria para o cenário atual de superlotação carcerária, tem-se a superação das dificuldades que permeiam o tema como a utilização de novas políticas públicas eficientes de curto prazo, o melhor aproveitamento de verbas públicas, a maior celeridade do judiciário, o oferecimento de personalidade à pena, a disponibilização de agentes carcerários mais preparados e respeito em geral às garantidas previstas aos encarcerados. 


\section{REFERÊNCIAS BIBLIOGRÁFICAS}

AGÊNCIA BRASIL. Com 726 mil presos, brasil tem terceira maior população carcerária do mundo. Disponível em:

$<$ http://agenciabrasil.ebc.com.br/geral/noticia/2017-12/populacao-carceraria-do-brasilsobe-de-622202-para-726712-pessoas>. Acesso em: 06 set. 2018.

BECCARIA, Cesare. Dos delitos e das penas. 2 ed. São Paulo: Edipro, 2015.

BORGES, Juliana. O que é: encarceramento em massa?. 1 ed. Belo Horizonte:

Letramento: justificando, 2018, P.31.

BRASIL. Código de Processo penal. Decreto-Lei 2.848, de 07 de dezembro de 1940. Disponível em: http://www.planalto.gov.br/ccivil_03/decretolei/Del2848compilado.htm. Acesso em 04 de setembro de 2018.

BRASIL. CONSELHO NACIONAL DE JUSTIÇA. Um em cada quatro condenados reincide no crime, aponta pesquisa. Disponível em: <cnj.jus.br/noticias/cnj/79883um-em-cada-quatro-condenados-reincide-no-crime-aponta-pesquisa $>$. Acesso em: 21 ago. 2018.

BRASIL. Constituição (1988). Constituição da República Federativa do Brasil. Disponível em: http://www.planalto.gov.br/ccivil_03/constituicao/constituicaocompilado.htm. Acesso em 04 de agosto de 2018.

BRASIL. Lei de execução penal. Lei no 7210 de 11 de julho de 1984. Disponível em: <http://www.planalto.gov.br/ccivil_03/LEIS/L7210.htm >. Acesso em: 01/09/2018

FOUCAULT, Michel. Vigiar e punir: nascimento da prisão. $42^{\mathrm{a}}$ ed. Petrópolis: Editora Vozes, 2014.

GRECO, Rogerio. Curso de direito penal: parte geral. 14 ed. Rio de janeiro: Impetus, 2014.

PIMENTEL, Manoel Pedro. Do crime continuado. ed., São Paulo: Editora Revista dos Tribunais, 2001, P.137.

ZAFFARONI, Eugenio Raúl. Em Busca das Penas Perdidas: a perda de legitimidade do sistema penal. Trad. Vania Romano Pedrosa, Amir Lopez da Conceição. 5. ed. Rio de Janeiro: Revan, 2012. p. 15. 


\title{
A INTERVENÇÃO DOS PARTICULARES NO SISTEMA PENITENCIÁRIO BRASILEIRO E OS POSSÍVEIS REFLEXOS DA INSUFICIÊNCIA DE PREVISÃO LEGAL
}

\author{
THE INTERVENTION OF PRIVATE PARTIES IN THE BRAZILIAN \\ PENITENTIARY SYSTEM AND THE POSSIBLE REFLECTIONS OF THE \\ INSUFFICIENCY OF LEGAL FORECAST
}

\author{
Brunna Fabrícia Albino Cavalcante ${ }^{1}$ \\ Orientadores: Prof ${ }^{\mathrm{D}}$. Me. Bruno Cavalcante Leitão Santos ${ }^{2}$ \\ Prof ${ }^{\circ}$. Dr. Hugo Leonardo Rodrigues Santos ${ }^{3}$
}

\begin{abstract}
RESUMO: O presente artigo constrói uma análise sócio-jurídica do crescimento exponencial e precoce da intervenção dos particulares no sistema penitenciário brasileiro por intermédio de contratos concessivos regulamentados sob a égide de normas genéricas. É notório que diante da crise carcerária, propício cenário violador de direitos fundamentais, sejam propostas as soluções mais imediatistas. A privatização dos presídios surge como um mecanismo hábil para sanar a ineficiência e ineficácia da Administração Pública através de uma menor onerosidade e efetivação das funções da pena. Entretanto, a insuficiência de previsão legal que estabeleça diretrizes específicas e métodos fiscalizadores para o particular, no exercício da gestão prisional, gera inúmeras lacunas que podem ser preenchidas com arbitrariedades e omissões contratuais, além da possibilidade de agravamento dos principais problemas do parque penitenciário nacional. Metodologicamente, teve como base uma pontual revisão bibliográfica, amparados com os mecanismos já existentes.
\end{abstract}

PALAVRAS-CHAVE: Privatização. Gestão Prisional. Parceria Público-Privada. Cogestão. Omissão normativa.

\footnotetext{
ABSTRACT: The present article constructs a socio-juridical analysis of the exponential and early growth of the intervention of individuals in the Brazilian penitentiary system, through concession contracts regulated under the aegis of generic norms. It is notorious

1 Graduanda no curso de Direito pelo Centro Universitário CESMAC - Maceió/AL. Contato: brunnacavalcante@hotmail.com.

${ }^{2}$ Doutorando em Direito (PUC/RS). Mestre em Direito Público (UFAL). Especialista em Direito Penal e Processo Penal (UCDB). Professor de Direito Penal do Centro Universitário CESMAC e da FAMA. Coordenador Adjunto (seccional Alagoas) do Instituto Brasileiro de Ciências Criminais - IBCCRIM; Coordenador do Laboratório de Ciências Criminais de Maceió-AL. Pesquisador do Grupo "Direito, contemporaneidade e transformações sociais" junto ao CNPq CESMAC-FEJAL. Contato: brunoleitao.adv@hotmail.com

${ }^{3}$ Doutor e mestre em Direito Penal pela UFPE; Pós-graduação em Direito Penal e Processual Penal pela ESMAPE; Professor no CESMAC; Coordenador adjunto do Instituto Brasileiro de Ciências Criminais IBCCRIM, em Alagoas. Membro da AIDP. Contato: hugoleosantos@yahoo.com.br
} 
that in the face of the prison crisis, a propitious scenario to violate fundamental rights, the most immediate solutions are proposed. The privatization of prisons appears as a skillful mechanism to remedy the inefficiency and ineffectiveness of the Public Administration through less onerosity and effective functions of the sentence. However, the lack of legal provision that establishes specific guidelines and monitoring methods for the private agent, in the exercise of prison management, generates numerous gaps to be filled with arbitrariness and contractual omissions, as well as the possibility of aggravating the main problems of the national penitentiary park. Methodologically, it was based on a punctual bibliographical revision, supported by the existing mechanisms.

KEYWORDS: Privatization. Prison Management. Public-Private Partnership. Comanagement. Normative omission.

\section{INTRODUÇÃO}

Decerto que o exercício do poder de punir do Estado varia de acordo ao somatório de fatores sociais, políticos, econômicos e ideológicos de cada local, em cada momento histórico. Isso reflete na constatação de que o desenvolvimento do sistema punitivo desde as penas cruéis e degradantes, utilizadas no período medieval, até a instituição da prisãopena, em meados do século XVIII, foi circundado por um complexo emaranhado de interesses, esculpindo um ambiente propício à estigmatização e à seletividade penal. Diante disso, embora a pena privativa de liberdade tenha representado um progresso à época, não demorou para que entrasse em colapso e refletisse negativamente na desordem e na usurpação de direitos dos presos.

A total precarização do sistema prisional é caracterizada pela superlotação das prisões, condições insalubres de manutenção, bem como pela ineficiência da máquina pública e a redução dos custos estatais nesse setor. Esses fatores constituíram o cenário conveniente para que os adeptos dos ideais neoliberais divulgassem a sua defesa pelo movimento privatizante do cárcere que estava se difundindo mundialmente, influenciado pelos modelos de gestão privada das unidades prisionais nos Estados Unidos e na Europa, como a solução mais viável para a crise carcerária brasileira.

A partir da importação das propostas de maior efetividade, eficiência e economicidade que a interferência dos particulares no sistema penitenciário poderia proporcionar, houve um crescimento vertiginoso dos contratos concessivos de serviços 
públicos prisionais sob a égide de normas regulamentadoras genéricas federais e estaduais. No entanto, observa-se que a implementação das parcerias entre o agente público e o privado foi executada de forma precoce e sem maiores estudos de viabilidade num contexto jurídico distinto. É em decorrência disso que o presente artigo pretende contribuir com a ampliação dos debates acadêmicos e sócio-jurídicos acerca do tema, porquanto é notória a insuficiência de produções científicas nesse âmbito, com vistas a explanar claramente os possíveis efeitos que a carência de normas pode ocasionar no campo fático.

Em que pese os debates jurídicos oficiais acerca do tema não tenham sido favoráveis a privatização dos presídios, a consolidação da gestão privada passou a se expandir pelo país. Dentre as possibilidades de intervenção do novo ator na execução penal, indo além dos modelos polares de gestão pública tradicional e da privatização integral do estabelecimento, foram implantados no Brasil os modelos de Cogestão e Parceria Público-Privada, ambos inspirados nos moldes da gestão mista adotada na França, a qual prevê a responsabilidade compartilhada do gerenciamento prisional entre o poder público e o particular.

A indagação principal da presente pesquisa, designada pela sua hipótese, é se a insuficiência de previsão legal que estabeleça diretrizes específicas e métodos fiscalizadores para o agente privado, no exercício da gestão prisional, poderia gerar arbitrariedades e omissões, viabilizadas pela existência de lacunas legislativas suscetíveis de desvios à concretização de regras internacionais, nacionais e, em consequência, do próprio Estado, asseguradoras da garantia dos direitos fundamentais dos presos, as quais respeitam a dignidade da pessoa humana como postulado basilar do Estado Democrático de Direito.

A metodologia utilizada para o desenvolvimento do artigo foi através do caráter exploratório, de modo a proporcionar um maior esclarecimento e clareza sobre o objeto estudado. Desse modo, também foram adotadas as pesquisas bibliográfica e documental para a construção do referencial teórico. Com a primeira, o estudo realizou-se a partir de livros, boletins, monografias, teses, dissertações e revistas; com a segunda, foi executada uma análise de documentos oficiais e jurídicos, publicações parlamentares e administrativas.

O objetivo principal de análise foi a legislação vigente e o PLS 513/2011, desenvolvendo a verificação do âmbito de incidência dessas normas na regulamentação 
do gerenciamento privado da prisão, além da sua (in)suficiência para o cumprimento contratual efetivo e para resguardar os direitos do preso. Quanto aos objetivos específicos, visou-se a análise do desenvolvimento histórico das prisões no Brasil até o cenário atual; a conceituação e estabelecimento das principais diferenças entre Parceria Público-Privada e Cogestão; o estudo das legislações em vigência no país, bem como se o Projeto de Lei $513 / 2011$ e os seus reflexos proporcionadores de recuo ou incentivo para ao gerenciamento privado prisional.

Este artigo foi construído com base na divisão em três capítulos. O capítulo inicial envolveu cronologia da perspectiva histórica das formas punitivas ao longo do tempo, perpassando pelo surgimento da prisão-pena, o desenvolvimento das prisões no Brasil e a posterior interferência privada nesse setor. O segundo capítulo explana sobre a construção conceitual dos modelos de Parceiras Público-Privada e de Cogestão, evidenciando um lento processo de adequação científica e jurídica em contraste ao rápido estabelecimento da privatização penitenciaria no país. Por fim, o último capítulo envolve um estudo mais ampliado, incluindo a análise das entrelinhas dos instrumentos jurídicos vigentes e em trâmite - PLS 513/2011 -, dos possíveis reflexos da insuficiência normativa na regulamentação da gestão privada das prisões frente à garantia de direitos fundamentais do preso.

\section{A HISTÓRIA DAS PRISÕES NO BRASIL E ONOVO" MODELO DE PERSPECTIVA GERENCIAL PRIVADA}

É de costume utilizar a frase em latim ubi societas ibi jus para explicar que "onde está o Homem, há sociedade; onde há sociedade há direito". Diante dessa afirmativa é possível observar que as relações humanas costumam ser regidas por regras informais, mas as formais são priorizadas para tutelar e assegurar os direitos individuais, coletivos e difusos. Assim, para o que é entendido como conduta reprovável, em cada momento histórico, há sanções estabelecidas de acordo à estrutura da sociedade, já que os tipos penais também acompanham as mudanças nos padrões sociais, ideológicos e, principalmente, político-econômicos.

Durante a Idade Média, o poder de punir estava submetido ao arbítrio dos governantes e a forte influência eclesiástica, sendo predominante a execução de penas 
corporais e estigmatizantes. Posteriormente, a Idade Moderna ascendeu associada ao rápido desenvolvimento industrial, alterando todo o panorama da sociedade em decorrência do êxodo rural e do repúdio à banalização das penas de morte em prol da necessidade de mão-de-obra laboriosa. Nessa época, com o advento do Estado Absolutista, o cenário punitivo fundado em exageros e desumanidade direcionados às classes sociais menos abastadas não foi alterado.

Não há questionamentos que, desde as mais remotas épocas da história, foram aplicadas variadas formas de sanções penais, tais como deportação, tortura, venda como escravo, galés, banimento, degredo (MAIA; et al, 2009a), de modo que até o início do século XVIII, o cárcere foi utilizado para garantir o cumprimento das penas prescritas que, em sua maioria, eram cruéis, degradantes e de morte, ou seja, "o encarceramento era um meio, não era o fim da punição" (CARVALHO FILHO, 2002, p. 21).

No Brasil, as dificuldades da realidade carcerária não eram diferentes, inclusive estaria agravada porque o país ainda vivia uma monarquia que perdurou durante quase dois séculos e meio, sendo fundada em divisões classistas e em uma sociedade escravocrata. Nesse contexto, já estava enraizada a segregação sociolegal entre brancos e negros, livres e escravos, ricos e pobres, bem como os estereótipos de cidadãos e delinquentes (AGUIRRE, 2009).

Sublinhe-se que as unidades penitenciárias não eram a preocupação dos representantes políticos das províncias durante o período colonial, evidenciado pelas condições informais, dissociadas do império da lei, o amontoado de suspeitos e condenados sem categorização de crimes e sem registros para designar os dados pessoais, as situações fétidas, insalubres e desumanas as quais eram submetidos, além da inexistência de instrumentos para recuperação dos aprisionados com propósito de uma melhor reinserção social (AGUIRRE, 2009).

\subsection{O contexto político-econômico do surgimento da prisão-pena}

Os primeiros modelos de prisão surgiram com a finalidade de atender aos interesses político-sociais resultantes da passagem da sociedade feudal-mercantilista para a capitalista, como a necessidade de controlar as massas atingidas pelo desemprego em larga escala, responsável, em boa parte, pela crescente criminalidade, além de sanar a escassez de mão-de-obra laboral. Assim, as casas de trabalho como as bridewells, rasp- 
huis, workhouses e masghuis foram criadas na Europa, na Inglaterra, na Holanda, nos Estados Unidos e na França, visando o desenvolvimento do sistema capitalista de produção através do disciplinamento dos corpos.

A partir do exposto é possível asseverar que o surgimento da pena privativa de liberdade chega a confundir-se com a origem do sistema capitalista de produção. À época, as prisões representaram um grande avanço frente ao seu antecessor, sistema punitivo cruel de penas corporais (GUEDES, 2010). Já por volta do final do século XVIII é possível perceber que a prisão vai se transformando no que a caracteriza na atualidade, com a assunção de três funções básicas: "punir, defender a sociedade isolando o malfeitor para evitar o contágio do mal e inspirando o temor ao seu destino, corrigir o culpado para integrá-lo a sociedade, no nível social que lhe é próprio" (PERROT, 1988, apud MAIA; et al, 2009a).

Nesse ínterim, a partir da difusão dos ideais iluministas e da Revolução Francesa, esta representando a dissolução do absolutismo, que alguns intelectuais como Cesare Beccaria (1738 - 1794), Jeremy Bentham (1748 - 1832) e John Horward (1726 - 1790) defendiam, além de movimentos reformistas penitenciários europeus e norte-americanos passaram a contestar o sistema punitivo em meados do século XVIII, principalmente, em defesa de um encarceramento mais humanitário, do caráter utilitário e proporcional da pena conforme o delito praticado.

Surgem, na Europa e nos Estados Unidos, a partir do final do mesmo século, os primeiros modelos de prisões modernas que se adequavam ao novo parâmetro de regras penais, sendo consideradas como um instrumento de humanização das penas e dignificação dos presos. Enquanto essas alterações no panorama punitivo ocorriam concretamente em países desenvolvidos de forma experiente e com dados da sua repercussão, no Brasil, apenas na década de 1830 esses discursos passaram a ser colocados em pauta diante de uma tentativa de adequação do sistema nacional aos novos parâmetros do Direito Penal mundial.

Vale ressaltar, que nessa época, o Brasil já havia conquistado a independência e estava sob a égide da Constituição do Império de 1824, a qual determinara mudanças no âmbito de aplicabilidade penal como a separação dos réus conforme a natureza dos seus delitos e regras básicas para a manutenção minimamente digna dos presos naquele ambiente (ENGBRUCH; SANTIS, 2012). Não obstante, os padrões hierárquicos, políticos e ideológicos de controle e exclusão social através do autoritarismo 
permaneceram, esculpindo a seletividade penal, sobretudo, em decorrência da continuidade do sistema monárquico e escravista.

Nesse cenário foi instituído o Código Criminal do Império em 1830 que introduziu a pena privativa de liberdade nas modalidades simples e com trabalho, certificando que o encarceramento deixara de ser utilizado como meio garantidor do castigo fim para tornarse a forma punitiva preponderante no decorrente século e seguintes. Porém, em contraposição à tendência internacional, o referido Código não adotou nenhum modelo penitenciário, delegando a responsabilidade aos governos provinciais (ENGBRUCH; SANTIS, 2012).

Não demorou para que os debates críticos acerca das condições carcerárias ganhassem ênfase diante do desapontamento com os resultados obtidos após os ditames constitucionais e legais, pois os objetivos prescritos não foram concretizados com excelência e logo os problemas como falta de infraestrutura básica das prisões, superlotação, insuficiente assistência material, médica, jurídica e social, além da precariedade na manutenção de higiene e salubridade voltaram a ser denunciados.

$\mathrm{Na}$ tentativa de atenuar os vícios das unidades prisionais do país frente à realidade pouco alterada, os estudiosos mantiveram seus julgamentos sobre o tema até a modificação do cenário político nacional, através da Proclamação da República em 1889, criar mais um foco de esperança. Diante da incompatibilidade da legislação penal anterior e, perante a necessidade punitiva imediatista, foi promulgado o Código Penal de 1890, o qual teve um papel relevante na normatização de um encarceramento mais humanizado, ao passo que aboliu as penas degradantes, perpétuas e de morte, estabeleceu quatro tipos de prisão: a celular, de reclusão, com trabalho e a disciplinar, definiu também um limite máximo de trinta anos para cumprimento de pena e adotou expressamente o Sistema Progressista Irlandês, além de inovar com a progressão da pena (ENGBRUCH; SANTIS, 2012).

Percebe-se que basta uma breve análise histórica para tornarem-se evidentes os problemas enfrentados no processo de estruturação das instituições penitenciárias para adequá-las aos ditames considerados minimamente salubres, dignos e humanos. No entanto, embora as legislações mais modernas já versassem sobre esses fatores, a realidade da aplicabilidade penal é muito diferente do que prescreve o campo legal, mesmo contrariando o caráter normativo e vinculante, pouco se vê de efetividade. 


\subsection{As origens das concepções modernas da interferência privada nos estabelecimentos penais}

Embora o advento da prisão-pena tenha constituído um progresso, não demorou para que a crise nos estabelecimentos carcerários se difundisse novamente pelo mundo, por volta do século XX, demonstrando a desordem, insuficiência de assistências básicas e situações atentatórias aos direitos humanos previstos em normas internacionais. Consequentemente, as críticas a esse cenário passaram a se intensificar mais uma vez. Esse foi o cenário adequado para que fossem retomadas, na década de 1980, as principais propostas de intervenção dos particulares na administração prisional, diante do caos em que se apresentavam os estabelecimentos prisionais, somado ao aumento alarmante do encarceramento em massa e a necessidade da redução dos altos custos correcionais (SANTOS, 2017).

Logo a defesa de um movimento direcionado à privatização do cárcere passa a disseminar os discursos das vantagens para os Estados que o adotassem, influenciando países como Reino Unido, França, Austrália e Brasil. Dando ênfase ao contexto brasileiro, a exportação desse modelo de gestão prisional privada ganhou a confiança do governo nacional até que chegou a ser debatido pela primeira vez, de forma oficial, através da pauta do Conselho Nacional de Política Criminal e Penitenciária (CNPCP) no ano de 1992. O posicionamento do CNPCP, com apoio da Ordem dos Advogados do Brasil $(\mathrm{OAB})$, foi contrário a privatização das prisões, mas não estabeleceu nenhum caráter vinculativo à decisão, deixando a cargo dos governos estaduais a instituição ou não dessa tendência, após uma análise de viabilidade (SANTOS, 2017).

Decerto esse entendimento não foi empecilho para que a perspectiva gerencial continuasse ganhando adeptos no país, inclusive motivados pelas propostas de maior eficiência da administração penitenciária, redução de custos públicos, criação de mais vagas nas prisões e realizando esses pontos com uma maior facilidade operacional e menos burocracia, pois estariam dispensadas licitações para maioria dos serviços. Assim, segundo eles, resolveriam o desastre da não garantia de direitos dos presos, o descontrole dos cofres estatais, o superpovoamento e a ineficiência das assistências, tal como a jurídica.

Nesse viés, a intervenção dos particulares nos presídios foi acolhida por governos estaduais, como no Paraná, pioneiro na implantação da terceirização de serviços na 
Penitenciária Industrial de Guarapuava - PIG, inaugurada em 1999. Ressalta-se que os cargos de diretor, vice-diretor e de diretor de disciplina permaneceram sob responsabilidade do ente público, visando à manutenção de uma gestão compartilhada entre este e o ente privado. E, mesmo que essa experiência inicial tenha sido interrompida posteriormente em 2006, em decorrência da variação de questões políticas governamentais, outras unidades federativas como Santa Catarina, Espírito Santo, Bahia, Minas Gerais, Tocantins, Alagoas e Amazonas já haviam manifestado interesse e adotaram o modelo (SANTOS, 2017).

É importante mencionar que rapidamente a experiência privatizante se expandiu pelo país, mesmo diante da edição da Resolução 08/2002 do CNPCP com intuito de consolidar o seu entendimento contrário a quaisquer propostas tendentes à privatização das atividades prisionais de forma geral, afirmando que incitaria a atividade negocial. Os modelos que adequaram-se à realidade brasileira foram os de Cogestão, o qual foi preferência de implantação na maioria das penitenciárias nesses moldes no país e, de Parceria Público-Privada (PPP), caso isolado do Complexo Penitenciário Público-Privado de Ribeirão das Neves/MG, ambos inspirados no modelo francês de compartilhamento de responsabilidades no gerenciamento da unidade prisional (GUEDES, 2010).

Contudo, embora Projetos de Lei tenham sido objeto de debates nas casas legislativas do país para regular a privatização dos presídios, como o PLS 513/2011, que ainda está em trâmite, ainda não foi aprovada nenhuma regulamentação específica para disciplinar a atuação do particular até a atualidade. Os contratos são apenas elaborados sob a égide de legislações federais genéricas, como a Lei 11.079/2004 que instituiu as parcerias público-privadas e da Lei 8.666/1993, reguladora das licitações e contratos da Administração Pública, além de legislações estaduais.

Logo, frente à precoce experiência brasileira com a perspectiva gerencial privada nas instituições correcionais, as produções acadêmicas e científicas nacionais acerca do tema ainda são insuficientes, evidenciando a carência de debates intelectuais, políticos e jurídicos sobre o crescimento exponencial das concessões e os reflexos atuais e futuros, através de análises do impacto econômico e orçamentário, da qualidade dos serviços prestados e do desempenho privado em contraposição ao público numa perspectiva comparada entre as prisões públicas e privadas. Em face disso, sublinhe-se que esse campo se mantém como um polêmico método importado de países com uma realidade política e social distinta do Brasil e que está sendo implantado sem maiores precauções, 
inclusive diante das características peculiares que devem ser observadas na vivência do cárcere.

\section{PARCERIAS PÚBLICO-PRIVADAS E COGESTÃO NOS ESTABELECIMENTOS PENAIS: UMA CONSTRUÇÃO CONCEITUAL DOUTRINÁRIA E LEGISLATIVA}

Enquanto a tendência privatizante das unidades prisionais do país demonstrava pressa em se expandir, as produções científicas e legislativas sobre o tema caminhavam em passos curtos e quase sempre as suas análises eram teóricas; já aqueles que desenvolviam in loco, estavam restritos aos reflexos de uma experiência recente, com insuficiência de dados concretos e de transparência. Embora o poder legislativo se fizesse tardio na produção de normas específicas sobre esse tema, outros instrumentos legais dotados de generalidade foram utilizados para legitimar esses modelos de gerenciamento prisional na realidade conceitual e jurídica nacionais.

Para os mais esperançosos defensores da interferência dos particulares, a importação de um novo modelo gerencial de prisões para o Brasil tem como objetivo minimizar ou até solucionar o caos presente no sistema penitenciário, acentuado pela ineficiência da atuação da Administração Pública no cumprimento das suas atividades legalmente determinadas e da contínua crise financeira da máquina pública, refletindo negativamente na realidade carcerária caracterizada por condições precárias de salubridade e habitação, não fornecimento de assistências mínimas, não concretização das finalidades da pena, favorecendo, assim, um ambiente extremamente criminógeno (PINHEIRO, 2016).

Diversas são as formas existentes de interferência dos particulares na administração prisional que perpassam entre os modelos polarizados de gestão pública tradicional e a privatização integral do estabelecimento, variando de acordo ao grau de interferência e as modulações contratuais. Contudo, admite-se que os dois grandes modelos de governança privada em prisões são os adotados nos Estados Unidos e na França. O modelo estadunidense tem como característica principal a transferência integral da administração penitenciária ao particular, envolvendo a elaboração do projeto, construção e operação completa da unidade, inclusive da vigilância interna; já o modelo 
francês, diferencia-se pelo compartilhamento de responsabilidades e atividades entre o Estado - permanece com as atividades de direção, vigilância interna e externa - e o agente privado - encarregado de gerenciar os serviços necessários pra manutenção de hotelaria e assistências materiais (AZEVEDO; CABRAL, 2012; PINHEIRO, 2016).

Uma vez que os modelos supracitados sejam dotados de características próprias, advindos de um contexto sócio-legislativo distinto, houve a necessidade de analisar a compatibilidade de ambos com o ordenamento jurídico pátrio para que pudessem adquirir validade e efetividade. Assim, propagaram-se inúmeras críticas sobre o modelo estadunidense, principalmente em decorrência das restrições constitucionais que determinam a indelegabilidade dos serviços essencialmente públicos e, no caso da administração dos presídios, trata-se da indelegável função jurisdicional do Estado na execução da pena e do exercício do poder de polícia. Logo, é vetada qualquer forma de privatização integral nesse ramo, a qual não há presença hierárquica da Administração Pública na gestão, isto é, não tem arcabouço jurídico para sua implantação no Brasil. De acordo com Pinheiro (2016, p. 602):

\begin{abstract}
se o Estado é ineficiente, argumenta-se, a iniciativa privada com seus modelos de gestão empresarial teria muito a ensinar e, se não há ambiente jurídico ou político para a completa privatização do sistema prisional, passa-se a defender um modelo semiprivado em que o particular desempenha atividades reputadas circundantes da realidade penitenciária, como trabalho, saúde, ensino, assistência médica e jurídica, ao passo que o Estado manteria consigo todos os incidentes de natureza jurisdicional, a segurança, a disciplina e a aplicação das regras de administração do presídio.
\end{abstract}

Com fulcro nessa explanação, conclui-se que é admitida no Brasil principalmente a implantação dos modelos inspirados na gestão mista francesa de dupla responsabilidade público-privada na administração da unidade. Ela foi importada como terceirização de serviços nas prisões, sendo adaptada ao contexto sócio-normativo vigente nas modalidades de Cogestão e de Parcerias Público-Privadas, com ênfase na manutenção do particular sob a supervisão e subordinação da Administração Pública. É válido ressaltar que "a participação da iniciativa privada nem sempre diz respeito à atuação empresarial, sendo possível que Organizações Não-Governamentais, igrejas ou mesmo os próprios presos desenvolvam a gestão prisional" (SANTANA, 2011 apud SANTOS, no prelo).

Não obstante, assevera o artigo 175 da Constituição Federal de 1988, sobre a viabilidade do Poder Público delegar a prestação dos serviços de sua titularidade exclusiva aos entes privados por meio de permissão ou concessão, através de licitação. 
Dessa forma, dentre as possibilidades concessivas, tem-se aquelas previstas para o modelo de Parcerias Público-Privadas, regido pela Lei 11.079/2004, a qual "estabelece que a prestação indireta de serviços possa ocorrer por intermédio do contrato administrativo de concessão, nas modalidades patrocinada ou administrativa" concessão especial. Foi proposta a modalidade administrativa como a mais adequada para as necessidades das unidades prisionais, diante das peculiaridades que as suas atividades e assistências requerem, pois sob a sua ótica, o serviço é prestado direta ou indiretamente à Administração Pública e o governo arca integralmente com a contraprestação pecuniária.

A Lei 11.079/2004 irradiou seus efeitos com precisão no sistema prisional, sendo fundamento para várias tentativas de implantação de PPP - constatando que o advento desse instrumento jurídico incentivou interesses mercantis nesse setor - como ocorreu nos Estados de Pernambuco, Alagoas e Minas Gerais, porém, apenas o último obteve êxito e todo o trâmite foi concluído, de modo que o Complexo Penitenciário PúblicoPrivado - CPPP - de Ribeirão das Neves/MG está funcionando desde 2013, gerido pela sociedade anônima Gestores Prisionais Associados - GPA.

Entende-se como PPP nos estabelecimentos penais, a contratação administrativa entre a Administração Pública e o parceiro privado, na qual este será responsável pelo projeto, construção, operação e financiamento, além do posterior gerenciamento da maioria dos serviços prisionais, pois, como preleciona o artigo $4^{\circ}$, III da lei em questão, deverão ser observadas a "indelegabilidade das funções de regulação, jurisdicional, do exercício do poder de polícia e de outras atividades exclusivas do Estado" para instituição da PPP. Em síntese, Rosato (2017, p. 1474) conceitua essa gestão com especificidade, esclarecendo que:

cabe à concessionária a construção do estabelecimento, que abrange o desenvolvimento de todos os projetos de arquitetura e engenharia, prestação de serviços como fornecimento de alimentação, vestuário, assistência médica e jurídica, bem como realização de programas de ressocialização do preso, sua profissionalização e preparação para o mercado de trabalho. A segurança interna também é de responsabilidade do particular. O Estado é responsável pela supervisão do contrato, pelo fornecimento de agentes penitenciários para efetuar a segurança externa, pelo transporte dos detentos e pela execução judicial da pena.

No modelo de Cogestão ou gerenciamento misto, por outro lado, prevalece a transferência da execução dos serviços ao particular disciplinada pela Lei 8.666/1993, Lei 
8.987/1995, bem como por leis estaduais. Como supracitado, a característica central da Cogestão é a operacionalização essencialmente compartilhada entre os contraentes Estado e o particular - da unidade prisional. Desse modo, estando atendidos os trâmites legais para instituição da Cogestão, bem como assegurado o processo licitatório regulamentado pela Lei 8.666/1993, estará designado que ao Estado incumbe o financiamento e execução da construção do estabelecimento penal, também a nomeação do diretor, vice-diretor e diretor de segurança - representantes do Estado na gestão contínua da unidade, além de promover a segurança externa da prisão. Já no que concernem as obrigações do parceiro privado estará à responsabilidade de promover o

fornecimento dos demais serviços necessários ao funcionamento do estabelecimento penal, o que inclui alimentação, vestuário, serviços de vigilância interna (executados por agentes penitenciários da empresa contratada), assistência médica, jurídica e social, bem como atividades que visam à reinserção do interno: trabalho prisional, cursos profissionalizantes, ensino fundamental e médio, dentre outros (CABRAL; LAZZARINI, 2010, p. 3).

O Estado ainda terá que, dentre outros encargos fixados contratualmente, acompanhar e fiscalizar a execução dos serviços para garantir as assistências previstas na Lei de Execução Penal e remunerar o particular através do pagamento de montantes fixos, com base na quantidade de aprisionados. Além disso, é evidente que a função jurisdicional continua sob o comando e controle do Estado, pois ele detém o poder de gerir a execução penal e de disciplinamento dos custodiados. Assim, entende-se como Cogestão o ato de "chamar e admitir a participação da sociedade, da iniciativa privada, para colaborar com o Estado na importante função de gerir as unidades prisionais" (CARVALHO, 2008 apud SANTANA, 2011, p. 14).

É evidente que o ponto cerne da delegação executória dos serviços é a satisfação dos anseios sociais por meio de atividades com maior qualidade e eficiência, devendo ser respeitada a exigência de um processo licitatório conforme regra a Lei 8.666/1993 - que "regulamenta o art. 37, inciso XXI, da Constituição Federal, institui normas para licitações e contratos da Administração Pública" - para ambas as formas concessivas, a clara responsabilização civil e o cumprimento contratual com vistas a assegurar as normas constitucionais e legais.

Decerto que a interferência dos particulares já está integrada no sistema de justiça punitivo brasileiro, valendo-se em maior ou menor grau em cada modelo de gestão e a partir dos mais diversos institutos contratuais (PINHEIRO, 2016). Essa assertiva se faz 
notória a partir dos dados oficiais divulgados pelo relatório da Pastoral Carcerária Nacional no ano de 2014, nos quais estipulam que até o referido ano havia cerca de 30 prisões privatizadas no país. Entretanto, através de dados coletados por intermédio de uma pesquisa recente sobre o tema ${ }^{4}$, foi possível a constatação que a exemplo do modelo de Parceria Público-Privada há somente uma unidade isolada, asseverando o exposto anteriormente acerca do CPPP de Ribeirão das Neves/MG e, em relação ao modelo de cogestão, totalizam 25 unidades prisionais, espalhadas pelo país, com exceção do CentroOeste (SANTOS, no prelo).

Importa frisar que não há um consenso doutrinário e legislativo quanto à conceituação desses modelos de intervenção dos particulares em presídios no Brasil (Cogestão e PPP), além de que alguns especialistas defendem que a designação correta para eles seja terceirização e não privatização, pois o ordenamento jurídico pátrio veda a delegação de serviços públicos essenciais. Essa dificuldade é enfrentada, principalmente, pela sua instituição precoce, como instrumentos de escape da máquina pública frente a sua ineficiência, visando à obtenção de resultados rápidos, porém geradores de possíveis consequências negativas num momento posterior, pois a busca pelo auxílio públicoprivado para uma melhor prestação de serviços materiais envolve, em sua maioria, àqueles designadores de direitos fundamentais e da dignidade da pessoa humana.

\section{OS IMPACTOS DA INSUFICIÊNCIA NORMATIVA NA REGULAMENTAÇÃO DA GESTÃo PRIVADA DAS PRISÕES FRENTE À GARANTIA DE DIREITOS FUNDAMENTAIS DO PRESO}

É inegável que a delegação de serviços públicos aos particulares está consolidada em diversas atividades no país, principalmente diante da forte influência neoliberal estabelecida na conjuntura brasileira há décadas. Ainda, percebe-se que a privatização perfaz efeitos até satisfatórios em algumas delas. Entretanto, a expansão desse gerencialismo para a realidade do ambiente prisional requer a observação de

\footnotetext{
${ }^{4}$ Informações coletadas em estudos vinculados à pesquisa que está sendo desenvolvida, com financiamento do Instituto de Pesquisa Econômica e Aplicada (IPEA), intitulada "Pensando o direito: identificação de atributos para a contratação de parceria público-privada ou cogestão na construção e administração de estabelecimentos penitenciários". O projeto é capitaneado pela Profa. Suzann Flávia Cordeiro de Lima (UFAL), e conta ainda com a participação do Prof ${ }^{\circ}$. Dr. Hugo Leonardo Rodrigues Santos, do Prof. Bruno Cavalcante Leitão Santos (CESMAC), Prof. Francisco de Assis França Júnior (CESMAC), entre outros pesquisadores.
} 
características peculiares que o compõe, ao qual possui um nível de complexidade mais elevado para a execução dos serviços, pois o encarceramento deve restringir apenas o direito de ir e vir do apenado, permanecendo, portanto, todos aqueles não atingidos pelos efeitos da pena.

Sob esse aspecto é importante mencionar que a atuação do agente privado deva ser determinada e fiscalizada constantemente pelo poder público para que o cumprimento contratual se faça efetivo e eficaz, sempre embasado nas necessidades, principalmente, daqueles que cumprem penas. Não obstante aos efeitos obrigacionais extraídos dos contratos, está evidente que diante do referido objeto concessivo do poder público ao particular é inconsistente e impensável que não estejam direcionados por instrumentos legislativos específicos - mas, atualmente, por leis genéricas - que versem sobre direitos e deveres de ambos os contraentes e suas respectivas atribuições aos apenados.

É fato que tal matéria já foi discutida legislativamente, como ocorreu com alguns Projetos de Lei a exemplo dos PL 2146/1999, PL 2003/1999, PL 714/1999 e PL 2825/2003 que foram rejeitados e arquivados, mediante fundamentações consistentes e embasadas na defesa da ordem constitucional e dos direitos humanos advindas de órgãos e instituições competentes como a OAB e o CNPCP, evidenciando a preocupação jurídica com esse novo mecanismo de gestão prisional (SANTOS, 2017). Os referidos entendimentos já especificavam algumas falácias divulgadas por seus defensores e as possíveis consequências negativas da sua implantação para o poder público e aprisionados, porém as propostas políticas não cessaram e novamente entrou na pauta do Congresso Nacional o debate sobre o tema através do Projeto de Lei 513/2011 do Senado, ao qual estabelece normas gerais para a contratação de parcerias público-privadas com a finalidade de construção e administração de estabelecimentos penais (SANTOS, no prelo).

Apesar disso, as tentativas legislativas não se fizeram suficientes para solucionar os vazios legais, de modo que desde a primeira experiência privatizante de unidades prisionais, a qual data há quase vinte anos, apenas a Resolução 08/2002 do CNPCP estabelece direcionamentos para o assunto (SANTOS, 2017). Evidencia-se a insuficiência de normas regulamentadoras para designar diretrizes específicas que disciplinem a atuação do agente privado na execução dos seus deveres contratuais, dificultando a imposição de regras comuns para assegurar o cumprimento dos objetivos estatais, inclusive com implicações nas funções declaradas da pena e na manutenção digna do 
cárcere. Refletem também na despadronização dos meios fiscalizadores e na ineficácia do monitoramento das obrigações contratuais.

As críticas em defesa da possível violação constitucional a partir da delegação das atividades prisionais de responsabilidade exclusiva do Estado ao particular no âmbito prisional tornaram-se mais acentuadas, inclusive pela omissão legislativa infraconstitucional em esclarecer os parâmetros de validade aptos a sua permissão. Até que em 2015, a Lei 13.190/2015 alterou a Lei de Execução Penal - LEP - que passou a regular claramente o assunto através dos artigos 83-B, cujo preceitua que "são indelegáveis as funções de direção, chefia e coordenação no âmbito do sistema penal, bem como todas as atividades que exijam o exercício do poder de polícia [...]”, além do artigo 83-A do mesmo instrumento normativo.

Conforme o supracitado está evidente que uma lei genérica foi utilizada mais uma vez para tentar sanar a lacuna legislativa da privatização de prisões com intuito de legitimar a atuação do agente privado nesse setor. De fato, aspectos importantes foram regulados de forma concreta, como a determinação do art. 83-A, $\S 1^{\circ}$ da LEP na qual "a execução indireta será realizada sob supervisão e fiscalização do poder público", porém o dispositivo está coberto de generalidade, de modo que não determinou os responsáveis para o exercício da fiscalização, tampouco quais os métodos e indicadores de desempenho seriam aptos a ensejar uma supervisão efetiva. Assim, resta aos diplomas legais locais e, respectivamente, aos contraentes decidirem como a fiscalização será conveniente a ambos (SANTOS, 2017).

Essa é uma questão que deveria ser observada de forma mais rigorosa pelas autoridades competentes, pois sem a existência de orientações ao órgão público em como proceder com os mecanismos fiscalizatórios do parceiro privado, além da determinação de métodos homogêneos em âmbito nacional para evidenciar os indicadores de desempenho das unidades privadas não será possível a obtenção de resultados claros e seguros do cumprimento das condições contratuais. Institui-se, assim, um grande reflexo negativo da insuficiência de previsão legal específica, porquanto, esse vazio legal poderá dar ensejo a inúmeras arbitrariedades por parte do particular em detrimento dos direitos e necessidades dos presos.

Outro reflexo seria a falta de imposição para a plena transparência de todo o trâmite concessivo, dos termos do contrato e da consequente execução das atividades delegadas nas prisões privadas, sendo extremamente restrito o acesso a essas 
informações, ao passo que não há subordinação constituída das empresas privadas ao interesse público. Surge mais um obstáculo à supervisão pública que, diferente do controle exercido nas prisões públicas mediante as imposições protetivas que determinam o acesso as informações sobre qualquer possível abuso e violação de direitos dos presos, nas prisões privadas não há dever de conceder o relatório informacional da realidade carcerária com a veracidade e completude necessárias (HERIVEL; WRIGHT, 2013).

Segundo o Relatório da Pastoral Carcerária sobre "Prisões privatizadas no Brasil em debate" (2014), constata-se que há falta de transparência na maior parte dos estados, fato crítico para a análise da atuação particular e, inclusive, do próprio poder público, pois a fiscalização contratual deve se dar nos dois pólos, de modo a assegurar que interesses políticos e particulares não se misturem e causem danos àqueles que deveriam ser objeto de proteção. Além disso, esse reflexo também emana efeitos para a falta e/ou divergências de informações sobre a condução das unidades privadas pelo agente privado, podendo gerar confusão nos papéis de quem detém a autoridade formal e real da unidade.

Ainda em relação aos indicadores de desempenho, é importante que sejam previstos e uniformizados legalmente aqueles que se refiram à qualidade e aos custos dos serviços prestados, através de uma aprofundada análise das características peculiares do cárcere por órgãos competentes e especializados, de modo que sejam elencados taxativamente em lei, só sendo permissível a ampliação para averiguação de atividades não essenciais a plena garantia das assistências correspondentes a manutenção digna dos presos nas prisões. Inclusive, alguns modelos de indicadores são propostos por Cabral e Lazzarini (2010, p. 398), explanados aqui a título meramente exemplificativo:

vistos sob este ângulo, os indicadores de ordem qualitativa no setor prisional, porém passíveis de mensuração quantitativa, podem ser agrupados em (a) indicadores de reincidência criminal; (b) segurança e ordem do estabelecimento (fugas, rebeliões, mortos, agressões sexuais); e (c) serviços oferecidos aos internos (assistência médica, jurídica, social, psicológica etc.).

A homogeneização dos indicadores de desempenho se dá com intuito de minimizar os interesses neoliberais do agente privado na busca pelo lucro - ponto cerne da atuação de toda atividade empresarial - a partir da privatização dos presídios. Além de prevenir que a qualidade das assistências e serviços sejam restringidos em detrimento da redução dos custos, o qual objetiva uma maior lucratividade, bem como viabilizar a manutenção da segurança e não violação dos direitos dos presos, porquanto, sabe-se que 
"ao se integrar a atividade punitiva ao interesse mercadológico da iniciativa privada busca-se a redução de custos e o aumento do lucro" (MESQUITA, 2017, p. 18).

Visando superar a lacuna legislativa evidenciada pela insuficiência de normas regulamentadoras específicas no âmbito das concessões público-privadas do gerenciamento dos estabelecimentos penais a qual implica nas possíveis consequências negativas supracitadas, foi elaborado o PLS 513/2011 que "institui normas gerais para a contratação de parceria público-privada, no âmbito da União, dos Estados, do Distrito Federal e dos Municípios, para a construção e administração de estabelecimentos penais". Atualmente, o referido Projeto de Lei continua tramitando no Congresso Nacional, sendo objeto de inúmeras discussões e críticas político-jurídicas sobre a constitucionalidade do seu texto, as possíveis violações veladas aos direitos dos presos, inclusive embasadas no objetivo central da ideologia neoliberal que é a obtenção de lucro e exploração do capital.

Alguns dos possíveis reflexos negativos abordados pelos críticos da interferência dos particulares no setor penitenciário são o agravamento do encarceramento em massa e a mercantilização da mão-de-obra do preso. E mesmo diante do PLS 513/2011 e sua justificativa em obter a efetiva ressocialização do preso, objetivo da execução penal, está expresso claramente no seu texto, art. $9^{\circ}$, que "o concessionário será remunerado com base na disponibilidade de vagas do estabelecimento penal, no número de presos custodiados e na prestação de serviços requerida pelo contrato". Estão evidenciados, a partir disso, os interesses político-econômicos na replicação do encarceramento, garantindo a superlotação das unidades penais, perpetuando a manutenção da clientela carcerária a fim de buscar o lucro (MESQUITA, 2017).

Em relação ao trabalho do preso, está definido no marco legal atual como um dever social e condição de dignidade humana, com finalidade educativa e produtiva (art. 28 e $\S \S$, LEP); já no texto do PLS 513/2011, o art. 10, caput e $\S 1^{\circ}$, versa sobre permissão do concessionário tenha "liberdade para explorar o trabalho dos presos, assim como utilizar ambientes do estabelecimento penal para a comercialização de produtos e serviços oriundos desse trabalho, e dos lucros advindos será deduzida a remuneração devida” [...], além de ressalvar a não sujeição do trabalho do preso a Consolidação das Leis do Trabalho, portanto, não constituindo relação de emprego entre o contratante da mão-deobra e o preso. Entende-se que este fator é um dos mais interessantes preceitos para a iniciativa privada ter legitimidade para explorar a mão-de-obra do preso, porquanto eles nem possuem proteções trabalhistas - como garantias laborais ou direito de se sindicalizar 
- nem liberdade para rescindir o contrato, podendo ser caracterizada como uma subordinação compulsória dos presos aos empresários (HERIVEL; WRIGHT, 2013; MESQUITA, 2017).

Está claro, diante do exposto, que a inexistência ou a insuficiência de previsão legal específica que discipline a atuação do agente privado, no exercício da gestão prisional, por meio de diretrizes especializadas e métodos fiscalizadores podem, eventualmente, dar ensejo à discricionariedade do particular. Portanto, faz-se notório que a ausência de normas regulamentadoras e de instrumentos de fiscalização garantidores do cumprimento dos objetivos estatais ocasionam diretamente a possibilidade de violação aos direitos fundamentais assegurados constitucionalmente aos presos, abrindo lacunas para abusos e arbitrariedades dos particulares.

\section{CONSIDERAÇÕES FINAIS}

Ante o exposto, é notória a interferência dos particulares como integrante efetiva no contexto penitenciário nacional, operando como um "novo ator" na execução penal, de modo a compartilhar as responsabilidades referentes às atividades materiais, de manutenção e segurança interna da unidade prisional com o poder público.

Além disso, quanto à análise de compatibilidade dos modelos de Cogestão e Parcerias Público-Privadas com o ordenamento jurídico pátrio, validado pela Constituição Federal, entende-se que não há impedimento para sua implantação, desde que não haja a delegação dos serviços essencialmente públicos - aqueles determinados como indelegáveis pela $\mathrm{CF} / 1988$.

Embora a tendência privatizante dos presídios tenha se expandido de forma acentuada em âmbito nacional, num curto espaço de tempo, é necessário que os modelos adotados sejam especificados e conceituados científica e legislativamente, para possibilitar estudos mais críticos e concisos sobre as suas características e reflexos.

Partindo desse pressuposto, está evidente a insuficiência de normas específicas regulamentadoras da atuação do particular na gestão das prisões, deixando um vazio de diretrizes básicas para que sejam efetivados os objetivos estatais no cumprimento das funções da pena. Porquanto, não se descarta a possibilidade do agente privado atuar com 
arbitrariedades e embasado nos interesses neoliberais, visando à obtenção de lucro em detrimento do respeito às garantias dos direitos fundamentais dos presos.

Os efeitos da omissão legal também se estendem a falta de normas que estabeleçam os parâmetros da físcalização dos presídios privatizados, quem será o responsável apto e imparcial designado para o feito, bem como quais serão os mecanismos fiscalizadores que assegurarão o efetivo cumprimento contratual por parte particular.

A regulamentação normativa também é importante para que se atenuem os possíveis reflexos da sua insuficiência, a exemplo da falta de transparência, do restrito acesso à informação, do agravamento encarceramento em massa, da exploração da mãode-obra do preso, dos abusos de direitos e arbitrariedades do agente privado.

Faz-se imprescindível, ademais, que os órgãos competentes possam executar uma análise mais aprofundada dos ideais privatizantes nesse setor, posto que as promessas dessa tendência poderão ser contrariadas, agravando a crise penitenciária e aumentando a onerosidade dos cofres públicos. 


\section{REFERÊNCIAS BIBLIOGRÁFICAS}

ARAUJO, Thais Maria Oliveira de. As modalidades de concessão do serviço público. Conteudo Juridico, Brasilia-DF: 10 mar. 2014. Disponivel em: $<$ http://www.conteudojuridico.com.br/?artigos\&ver=2.47296\&seo=1>. Acesso em: 23 jan. 2018.

BRASIL. CONSTITUIÇÃO DA REPÚBLICA FEDERATIVA DO BRASIL DE 1988. Disponível em: $<$ http://www.planalto.gov.br/ccivil_03/constituicao/constituicao.htm>. Acesso em: 02 jun. 2017.

Congresso Nacional. Projeto de Lei do Senado $n^{\circ} 513$ de 2011. Estabelece normas gerais para a contratação de parceria público-privada para a construção e administração de estabelecimentos penais. Disponível em: < https://legis.senado.leg.br/sdleggetter/documento?dm=2947751\&disposition=inline >.Acesso em: 07 jun. 2017.

Lei $\mathbf{n}^{0}$ 11.079, de 30 de dezembro de 2004. Institui normas gerais para licitação e contratação de parceria público-privada no âmbito da administração pública. Disponível em:< http://www.planalto.gov.br/ccivil_03/_ato20042006/2004/lei/l11079.htm>. Acesso em: 10 jul. 2017.

Lei no 8.666, de 21 de junho de 1993. Regulamenta o art. 37, inciso XXI, da Constituição Federal, institui normas para licitações e contratos da Administração Pública e dá outras providências. Disponível em:< http://www.planalto.gov.br/ccivil_03/Leis/L8666cons.htm>. Acesso em: 10 jun. 2017.

Lei $n^{\circ}$ 8.987, de 13 de fevereiro de 1995. Dispõe sobre o regime de concessão e permissão da prestação de serviços públicos previsto no art. 175 da Constituição Federal, e dá outras providências. Disponível em: <http://www.planalto.gov.br/ccivil_03/leis/L8987compilada.htm>. Acesso em: 25 jun. 2017.

CABRAL, Sandro; AZEVEDO, Paulo Furquim. Terceirização das prisões: notas de uma análise comparada. In: COELHO, Maria Tereza Ávila Dantas; CARVALHO FILHO, Milton Júlio (Org.) Prisões numa abordagem interdisciplinar. Salvador: EDUFBA, 2012.

.The Modes of Provision of Prison Services in a Comparative Perspective. Brazilian Administration Review, p. 53-69, 2008.

CABRAL, Sandro; LAZZARINI, Sergio. Impactos da Participação Privada no Sistema Prisional: Evidências a partir da Terceirização de Prisões no Paraná. RAC, Curitiba, v. 14, n. 3, art. 1, pp. 395-413, Mai./Jun., 2010.

CARVALHO FILHO, Luiz Francisco. A prisão. São Paulo: Publifolha, 2002.

DESSOTTI, Mariana. PPP no sistema penitenciário brasileiro - Constitucionalidade e Eficiência. Disponivel em: 
$<$ https://marianazanardodessotti.jusbrasil.com.br/artigos/170297252/ppp-no-sistemapenitenciario-brasileiro>. Acesso em: 23 jan. 2018.

ENGBRUCH, Werner; SANTIS, Bruno Morais di. A evolução histórica do sistema prisional e a Penitenciária do Estado de São Paulo. Revista Liberdades , São Paulo, $\mathrm{n}^{\mathrm{o}}$ 11, Páginas 01-22, setembro/dezembro de 2012.

FOUCAULT, Michel. Vigiar e punir: nascimento da prisão. 24. ed. Petrópolis: Vozes, 1987

GAES, Gerald G. Prison Privatization in Florida: Promise, Premise, and Performance. National Institute of Justice,p. 83-88, 2005.

GUEDES, Cristiane Achilles. A Parceria Público-Privada no sistema prisional. In: Revista do CAAP. Belo Horizonte, p. 65-76, jan-jun 2010.

HERIVEL, Tara; WRIGHT, Paul. Quem lucra com as prisões: O negócio do grande encarceramento. Rio de Janeiro: Revan, 2013.

MAGALHÃES, Inês Filipa Rodrigues de. Implicações Constitucionais, Penais e Processuais Penais da Intervenção de Atores Privados no âmbito da Execução Penal: A Reserva de Administração. In: ANTUNES, Maria João; SANTOS, Cláudia Cruz; AMARAL, Cláudio do Prado (Org.). Os Novos Atores da Justiça Penal. São Paulo: Almedina, 2016.

MAIA, Clarissa Nunes. et al. História das Prisões no Brasil, volume I. Rio de Janeiro: Editora Rocco, 2009a.

$2009 b$.

História das Prisões no Brasil, volume II. Rio de Janeiro: Editora Rocco,

MESQUITA, Luisa Angélica Mendes. Análise crítica da privatização do cárcere como solução aos problemas penitenciários. In: Revista transgressões: Ciências criminais em debate. São Paulo, v. 5, n. 2, maio 2017.

MONTEIRO, Ingrid Maria Sideaux Baratta. Sistema Penitenciário: Co-gestão, uma realidade. 2007. 53f. Monografia - Universidade Estadual do Ceará, Fortaleza, 2007. PASSOS, Anderson Santos. Os particulares na execução penal: a privatização de estabelecimentos prisionais no Brasil sob uma perspectiva Jurídico-Constitucional. In: ANTUNES, Maria João; SANTOS, Cláudia Cruz; AMARAL, Cláudio do Prado (Org.). Os Novos Atores da Justiça Penal. São Paulo: Almedina, 2016.

PASTORAL CARCERÁRIA NACIONAL. Prisões privatizadas no Brasil em debate. Coordenação de obra coletiva: José de Jesus Filho e Amanda Hildebrand Oi. São Paulo: ASAAC, 2014. Disponível em: <http://carceraria.org.br/wpcontent/uploads/2014/09/Relato\%CC\%81rio-sobreprivatizac\%CC\%A7o\%CC\%83es.pdf>. Acesso em: 15 dez. 2017.

PINHEIRO, Lucas Corrêa Abrantes. Parcerias Público-Privadas no Sistema Prisional Brasileiro: o Particular como Novo Ator e as implicações desse modelo. In: ANTUNES, 
Maria João; SANTOS, Cláudia Cruz; AMARAL, Cláudio do Prado (Org.). Os Novos Atores da Justiça Penal. São Paulo: Almedina, 2016.

ROSATO, Larissa. A privatização dos presídios como mecanismo de funcionamento da execução penal. $1^{\circ}$ Simpósio sobre Constitucionalismo, Democracia e Estado de Direito.

SANTANA, Aline Passos de J. Parcerias Público-Privadas no sistema prisional: modulações de controle e expansão de encarceramentos. Anais do XXVI Simpósio Nacional de História - ANPUH. São Paulo, 2011.

SANTOS, Hugo Leonardo Rodrigues. Gerencialismo e Privatização do Sistema Penitenciário Brasileiro: o caso da cogestão prisional. No prelo.

SANTOS, Ronny Peterson Nunes dos. Pivatização de Presídios no Brasil: reflexões à luz de um possível recuo da experiência americana. Dossiê Especial Encarceramento em massa. Revista Brasileira de Ciências Criminais, v. 129, ano 25, pp. 375-405. São Paulo: Ed. RT, 2017. 


\title{
A RELAÇÃO ENTRE OS DIREITOS FUNDAMENTAIS E A RESSOCIALIZAÇÃO EM MEIO AO ENCARCERAMENTO EM MASSA
}

\author{
THE RELATIONSHIP BETWEEN FUNDAMENTAL RIGHTS AND \\ RESSOCIALIZATION IN THE MEANS OF MASS INCARCERATION
}

\author{
Carolina Fontes Lima Tenório ${ }^{5}$
}

\begin{abstract}
RESUMO: Como objetivo mor do presente trabalho, faz-se uma análise crítica da relação entre a garantia dos Direitos Fundamentais dos detentos, no decorrer do cumprimento da pena privativa de liberdade, e a efetivação da ressocialização destes. Destarte, traz-se o seguinte questionamento central: como a aplicação dos Direitos Fundamentais no Sistema Carcerário pode influenciar na efetivação da ressocialização dos detentos? Para desfechar acerca de tal problemática, este escrito vale-se de uma pesquisa bibliográfica doutrinária acerca da relação principiológica existente entre os ramos do Direito Penal e Constitucional.
\end{abstract}

PALAVRAS-CHAVE: Direitos Fundamentais; Encarceramento em Massa; Funções da Pena; Ressocialização; Sistema Penitenciário.

ABSTRACT: The objective of this study is to critically analyze the relationship between the guarantee of the Fundamental Rights of detainees during the execution of the sentence of deprivation of liberty and the effectiveness of their resocialization. Thus, the following central question arises: how can the application of Fundamental Rights in the Prison System affect the effectiveness of the resocialization of detainees? In order to address this problem, this paper draws on a bibliographical research on the doctrinal relationship between the branches of Criminal and Constitutional Law.

KEYWORDS: Fundamental Rights; Mass Imprisonment; Functions of the Penalty; Ressocialization; Penitentiary System.

\section{INTRODUÇÃO}

Ao passo que os índices de criminalidade e insegurança pública crescem cada vez mais, chegando a níveis alarmantes, a sociedade, de forma geral, vê seus direitos sendo amplamente desrespeitados e, consequentemente, se volta contra os autores das

\footnotetext{
${ }^{1}$ Graduanda em Direito pelo Centro Universitário Tiradentes (UNIT).
} 
ações criminosas. Ocorre que, algo que, até certo ponto, é natural, tem extrapolado os limites de maneira despropositada e insensata, fazendo com que a "Justiça com as próprias mãos" se torne algo desejado por muitos que, em virtude da situação, desacreditam na função punitiva da punição aplicada pelo Estado.

Ademais, por outro viés, percebe-se que, os cidadãos passaram a crer no mito do Encarceramento em Massa, isto é, que encarcerar o maior número de criminosos possível - e até além disso - seria a solução para a redução dos níveis de criminalidade e insegurança pública, depositando, assim, esperança demais em uma ação do Estado, enquanto este se mostra despreparado para fazê-la de forma eficaz, não sendo capaz de garantir nem mesmo os Direitos Fundamentais daqueles que estão cumprindo pena privativa de liberdade em regime fechado.

Assim sendo, o presente escrito ostenta o seguinte questionamento: como a aplicação dos Direitos Fundamentais no Sistema Carcerário pode influenciar na efetivação da ressocialização dos detentos? Pois, é inegável que tais direitos, devido à sua basilaridade, são indispensáveis para remoldar um indivíduo, entretanto, não se pode afirmar que estes sejam os únicos responsáveis por isto, uma vez que, é certo que garantias são necessárias, mas em excesso estas podem vir a ser prejudiciais à função punitiva da Pena.

\section{OS DIREITOS FUNDAMENTAIS}

Os Direitos Fundamentais foram positivados ainda no Título II da Constituição Federal de 1998, sendo tidos como os verdadeiros suportes do ordenamento jurídico brasileiro, uma vez que englobam os direitos e liberdades basilares para a vida digna, compreendidos como direitos individuais e coletivos, sociais, de nacionalidade, políticos e relacionados à participação dos partidos políticos e sua organização. Ademais, o legislador constituinte também estabeleceu no artigo $60, \S 4^{\circ}$, IV, que tais direitos seriam uma Cláusula Pétrea, quer dizer, que não podem ser excluídos do texto constitucional, deixando clara a sua demasiada importância para a manutenção da democracia.

\subsection{Referencial Histórico}


Para que seja viável tratar dos Direitos Fundamentais brasileiros atuais, é mais do que preciso iniciar tratando dos marcos históricos mais relevantes para a conceituação e composição destes. Assim sendo, o presente subtópico se destina a explanação acerca de dois conceitos magnos no que diz respeito à conquista de direitos em âmbito internacional, sendo eles os Direitos Humanos e a Dignidade da Pessoa Humana.

\subsubsection{Direitos Humanos}

A doutrina assegura que os Direitos Humanos são as verdadeiras regalias internacionais básicas que devem ser ofertadas a todos, em qualquer lugar e em qualquer condição, apenas pelo simples fato de serem humanos ${ }^{6}$. Assim, tais direitos são, ou, ao menos, deveriam ser, as bases dos mais diversos ordenamentos jurídicos, uma vez que estes têm por sua função primordial a de estipular as liberdades e os direitos de extrema necessidade para a existência e preservação de uma vida digna.

A premência pela elaboração e defesa de direitos à nível global se deu no decorrer da Segunda Guerra Mundial, época marcada por grande horror e supressão de direitos, e, posteriormente ao fim desta, surgiu a Organização das Nações Unidas (ONU), com o objetivo de proteger os direitos de todos os humanos. Destarte, em 1948, a ONU promoveu a propagação da Declaração Universal dos Direitos do Homem, diploma este que fez com que os supracitados direitos fossem positivados em diversos Estados ao redor do mundo ${ }^{7}$.

Na realidade contemporânea, a ONU continua perdurando como representante e defensora a nível global dos Direitos Humanos e, consequentemente, tendo o poder de agir em qualquer país que esteja em um estado considerado de necessidade ${ }^{8}$, atuando de modo a demandar medidas estatais com vistas a garantia dos supramencionados direitos. Ademais, a drástica situação de violência dentro dos presídios brasileiros, assim como as

\footnotetext{
${ }^{6}$ ALVES, J. A. Lindgren. Direitos Humanos como Tema Global. $2^{\text {a }}$ Edição, São Paulo: Perspectiva, 2011.

${ }^{7}$ UNIDOS PELOS DIREITOS HUMANOS. A Declaração Universal dos Direitos Humanos. Disponível em: http://br.humanrights.com/what-are-human-rights/universal-declaration-of-human-rights/articles-2130.html. Acesso em: 14 de dezembro de 2018.

${ }^{8}$ ROMÃ̃, Wagner de Melo. RODRIGUES, Thiago. ONU no Século XXI. Perspectivas. $2^{a}$ Edição, Desatino, 2011.
} 
revoltas advindas dela, chegaram níveis tão alarmantes que resultaram, no ano de 2017, em um posicionamento da ONU solicitando ações para solucionar este problema.

Não há como negar que os Direitos Humanos serviram como norteadores para a elaboração, bem como a positivação constitucional, dos Direitos Fundamentais no Brasil, principalmente em razão das constantes ações da ONU para propagação de tais direitos. Ainda assim, é certo que a Dignidade da Pessoa Humana foi outra base importante para nosso ordenamento jurídico, pois ela está na essência dos Direitos Fundamentais brasileiros e até dos próprios Direitos Humanos.

\subsubsection{Dignidade da Pessoa Humana}

A Dignidade da Pessoa Humana foi originada antes mesmo dos Direitos Humanos; de acordo com Ingo Sarlet, não seria viável dar à Dignidade da Pessoa Humana um conceito em âmbito internacional, pois, ampla diversidade cultural que permeia as sociedades impossibilitaria isso ${ }^{9}$. Todavia, a doutrina brasileira a conceitua como sendo a reunião dos valores substanciais para que se possa viver com dignidade e bem-estar.

Ademais, no Brasil, houve uma preocupação do legislador constituinte em positivar tal conceito de forma a garantir uma ampla proteção da Dignidade da Pessoa Humana. Para tanto, o artigo $1^{\circ}$, inciso III, da Constituição Federal trouxe ela como um Fundamento da República e sua efetivação a tornou um dos maiores "Superprincípios"10 que já existiu. Além disso, tal Fundamento está intimamente ligado aos Direitos Fundamentais, uma vez que estes direitos seriam justamente uma ampliação do conceito de Dignidade da Pessoa.

Para mais, existem duas diferentes visões sobre o termo 'Dignidade', de forma que a adoção de uma das duas visões impacta diretamente na maneira de aplicação Dignidade da Pessoa Humana por parte de um Estado ${ }^{11}$. Historicamente, primeira acepção a ser conceituada foi a Negativa, diante da qual o governo estatal seria responsável por garantir apenas o direito à vida, independente das condições sob as quais

\footnotetext{
9 SARLET, Ingo Wolfgang. Dignidade da pessoa humana e direitos fundamentais na Constituição Federal de 1988. Porto Alegre: Livraria do Advogado, 2012.

${ }^{10}$ Idem.

${ }^{11}$ SARLET. Ingo Wolfgang. O Supremo Tribunal Federal e o Direito à Vida. In Revista de Direito da Universidade de Brasília, Páginas 184 a 201, 2014.
} 
tal vida tivesse que ser levada; esta acepção foi bastante considerada previamente ao surgimento da Teoria dos Direitos Humanos, todavia, com o advento de tal teoria, a acepção Negativa tornou-se insuficiente para as novas necessidades do povo.

Dessarte, foi desenvolvida uma nova acepção, sendo esta a Positiva, que é adotada no ordenamento jurídico brasileiro contemporâneo e determina que além de garantir o direto à vida, o Estado também deveria garantir que esta vida fosse levada com o bem-estar necessário para que se pudesse dizer que havia dignidade em viver daquele modo. Assim, além de se tratar de uma ferramenta habitual para que o povo pudesse se proteger de eventuais desmandos do governo, a Dignidade da Pessoa Humana englobava, também, os direitos e as garantias fundamentais para a vida humana.

\subsection{Direitos Fundamentais X Garantias Fundamentais: Uma Diferenciação Necessária}

Embora por vezes os Direitos e as Garantias sejam tidos como análogos, é certo que tais termos possuem suas divergências entre si; não obstante, com base na hermenêutica constitucional, a grande maioria da doutrina traz à tona a necessidade de diferenciar tais termos para que seja viável a obtenção de uma maior compreensão acerca de suas funções jurídicas ${ }^{12}$.

Deste modo, os Direitos são positivados em leis que possuem capacidade declarativa, ou seja, eles expressam a existência de uma regalia social. Assim, como citado anteriormente, os Direitos Fundamentais são a previsão constitucional dos direitos basilares para o bem-estar humano. Por outro lado, as Garantias possuem a função de certificar que os direitos legislados serão assegurados e, principalmente, aplicados, tendo, portanto, um caráter assecuratório. Dessa forma, as Garantias Fundamentais têm o papel de respaldar a efetivação dos direitos, independente de eles serem fundamentais ou não. Neste ínterim, trazendo tais conceitos para o tema abordado no presente artigo, podemos

\footnotetext{
12 SILVA, Flavia Martins. Direitos Fundamentais. Disponível em: https://www.direitonet.com.br/artigos/exibir/2627/Direitos-Fundamentais. Acesso em 06 de dezembro de 2018.
} 
expor, como exemplo de Garantia Fundamental, o Habeas Corpus, o qual salvaguarda o Direito Fundamental à liberdade ${ }^{13}$.

\section{O ESTADO DEMOCRÁTICO DE DIREITO}

A Constituição Federal vigente determinou, ainda em seu artigo $1^{\circ}$, que a República Federativa do Brasil se constituiria em um Estado Democrático de Direito, fundamentado no princípio da Soberania Popular, pressupondo, assim, a participação popular na "Coisa Pública" defendida pela doutrina constitucionalista ${ }^{14}$, sendo que tal participação não poderia se restringir à uma simples eleição de representantes, devendo ir muito além disso, requerendo da administração estatal tudo aquilo que fosse necessário para garantia de uma vida digna dotada de bem-estar para todos os cidadãos, sem distinção de qualquer espécie.

Para mais, a definição doutrinária de Estado Democrático de Direito o estabelece como sendo um governo que objetiva efetivar e aplicar as liberdades básicas de seus cidadãos $^{15}$. Assim sendo, as leis deveriam ratificar as pretensões e necessidades dos cidadãos de forma tanto coletiva quanto difusa; destarte, por conseguinte, tal Estado se materializaria, primeiramente, no respeito dos Direitos e Garantias Fundamentais estabelecidos em sua Lei Maior.

\subsection{A Cidadania}

A Cidadania é compreendida como sendo o devido exercício, por parte dos cidadãos, dos e deveres legais, sejam esses civis, políticos ou sociais, estabelecidos pela Carta Constitucional de um Ordenamento Jurídico. Dessarte, o exercício da cidadania

13 GOMES, Luiz Flávio. Existe diferença entre direitos e garantias fundamentais? Disponível em: https://lfg.jusbrasil.com.br/noticias/1060567/existe-diferenca-entre-direitos-e-garantias-fundamental. Acesso em 06 de agosto de 2018.

${ }^{14}$ SILVA, José Afonso. Estado Democrático de Direito. Revista de Direito Administrativo, Rio de Janeiro, 1988.

15 STRECK, Lênio Luiz; MORAIS, José Luís Bolzan. Ciência Política e Teoria Geral do Estado. $8^{\text {a }}$ Edição Porto Alegre: Livraria do Advogado, 2013. 
pressupõe que haja uma ligação clara entre os direitos e deveres como maneira de contribuir para a manutenção de uma sociedade equilibrada e justa.

Além disso, é extremamente preciso explanar que a cidadania se estende a todos independente de sua condição social, que dizer, estar cumprindo uma pena privativa de liberdade, mesmo que em regime fechado, não pode interferir na cidadania de forma além da razoável, uma vez que não se perde o caráter de cidadão por estar cumprindo uma pena. De fato, é certo que certos direitos deverão ser restringidos temporariamente no decorrer do cumprimento da sanção penal, todavia, esta restrição deve cumprir com as funções de tal sanção - punir e ressocializar.

Outrossim, evidencia-se que a ressocialização de um apenado só seria plenamente alcançada mediante a reinserção deste na sociedade, o que requer o exercício da cidadania. Para tanto, infere-se que o tratamento dos detentos como cidadãos se mostra como sendo de grande relevância para que se possa alcançar a função ressocializadora da pena e, consequentemente, efetivar a pena como um todo.

\subsection{As Políticas Públicas Carcerárias}

Embora seja certo que as Políticas Públicas possuem grande importância em qualquer Ordenamento Jurídico, estas são dotadas de uma maior relevância quando aplicadas em um Estado Democrático de Direito como o brasileiro, pois, ainda que sua definição seja um tanto quanto abstrata, estas são concretizadas na forma de projetos públicos e ações governamentais voltadas para a aplicação dos Direitos e as Garantias Fundamentais ${ }^{16}$ e, consequentemente, para a efetivação da Democracia.

Na realidade contemporânea, é de conhecimento geral que grande parte das políticas públicas não é devidamente efetivada nem tão pouco aplicada, situação esta que se agrava ainda mais dentro das Casas Prisionais; se para os que estão em liberdade a má efetivação das políticas públicas aplicadoras dos Direitos Fundamentais gera um desconhecimento das parcelas mais desfavorecidas da população para com estes, para aqueles que estão encarcerados tal situação resultou num estado de descaso tão grande

\footnotetext{
${ }^{16}$ SECCHI, L. Políticas Públicas: Conceitos, esquemas, casos práticos. $2^{\text {a }}$ Edição. São Paulo: Cengage Learning. 2013.
} 
que estes, muitas vezes, não sabem nem mesmo que são cidadãos, já que não são tratados como tal.

\subsubsection{O Mínimo Existencial}

O Mínimo Existencial é um princípio tido como um grande pilar para a vida humana, tendo como função a garantia da aplicação da acepção positiva da Dignidade da Pessoa Humana. Destarte, determina que a garantia das necessidades basilares dos cidadãos será sempre uma das obrigações imprescindíveis do governo estatal, não devendo este viabilizar políticas públicas que apliquem menos do que esse mínimo de dignidade $^{17}$.

Além disso, o Mínimo Existencial deveria ser um instrumento de defesa dos cidadãos para exigir que o Estado lhes garantisse as prerrogativas necessárias para a vida e o bem-estar, todavia, o que se observa nas Políticas Públicas Carcerárias é que a clara desconsideração da cidadania dos detentos faz com que, por diversas vezes, a própria administração das casas prisionais não se preocupe em garantir-lhes o mínimo de dignidade, fato este que contraria de forma descarada os preceitos básicos do Estado Democrático de Direito.

\subsubsection{A Reserva do Possível}

O princípio da Reserva do Possível foi importado da doutrina alemã e deve ser aplicado aos casos em que o governo se abstém da obrigação de garantir algum Direito Fundamental, tendo que segmentá-lo, sob a justificativa da ausência de orçamento disponível viável para aplicar uma política pública ${ }^{18}$. Ademais, tal qual o Mínimo Existencial se mostra, ou, ao menos, deveria se mostrar, como um instrumento de defesa

17 TOLEDO, Cláudia. Mínimo Existencial - A Construção de um Conceito e seu Tratamento pela Jurisprudência Constitucional Brasileira e Alemã. In: MIRANDA, Jorge et al. (org.). Hermenêutica, Justiça Constitucional e Direitos Fundamentais. Curitiba: Juruá, 2016, pp. 821 - 834.

${ }^{18}$ SARLET, Ingo Wolfgang. FIGUEIREDO, Mariana Filchtiner. Reserva do possível, mínimo existencial e direito à saúde: algumas aproximações. Revista de Doutrina da $4^{\mathrm{a}}$ Região, Porto Alegre, n. 24, jul. 2008. Disponível em: <http://www.revistadoutrina.trf4.jus.br/artigos/edicao024/ingo_mariana.html>. Acesso em: 04 de dezembro de 2018. 
dos cidadãos, a Reserva do Possível, em contrapartida, se apresenta como uma legítima defesa do Estado $^{19}$.

É necessário asseverar que não seria correto utilizar tal princípio de forma que ultrapassasse o razoável, já que, caso fosse aplicado de forma exacerbada, haveria um enorme prejuízo tanto democrático quanto social, pois, a Reserva do Possível pressupõe a efetivação das normas, principalmente as constitucionais ${ }^{20}$. Todavia, é justamente isso que se observa em relação às Políticas Públicas Carcerárias, uma vez que, cada vez mais observa-se que o Estado tem usado a justificativa da Reserva do Possível para deixar de cumprir sua função como aplicador dos Direitos Fundamentais dos detentos, motivo este que inviabiliza completamente a ressocialização destes.

\subsubsection{Eficácia $X$ Aplicabilidade}

É de conhecimento geral que, inúmeras vezes, os termos Eficácia e Aplicabilidade são considerados como congêneres, entretanto, a doutrina jurídica brasileira se atenta em diferenciar os conceitos de tais termos como forma de possibilitar o emprego correto destes e um maior aprofundamento nas funções estatais.

À vista disso, a Eficácia pode ser tida como a capacidade que uma norma, ou, neste caso, uma política pública carcerária, detém de produzir efeitos jurídicos, por outro viés, a Aplicabilidade se relaciona à maneira como uma norma será posta em prática, isto é, à capacidade de fazer com que uma política pública saia do papel, sendo devidamente colocada em prática ${ }^{21}$. Por conseguinte, infere-se que, por existir uma relação profundamente clara entre tais termos, uma política pública carcerária só poderá ser aplicável na medida em que for eficaz; assim, entende-se que a situação atual de desrespeito aos Direitos Fundamentais dos apenados como motivação para a ausência de ressocialização se trata de um problema que envolve tanto a efetivação quanto a aplicação destes.

19 PIRES. Anthônio. Mínimo existencial $\mathbf{x}$ reserva do possível. Disponível em: https://antoniopires.jusbrasil.com.br/artigos/121940660/minimo-existencial-x-reserva-do-possivel. Acesso em 04 de dezembro de 2018.

${ }^{20}$ VAZ. Carlos. A. L. A Aplicação Limitada da Reserva do Possível. Libertas, Ouro Preto - MG, v.2 n.1, jan./jun. 2016. Páginas 245 a 273.

${ }^{21}$ SARLET, Ingo Wolfgang. A Eficácia dos Direitos Fundamentais. 12a Edição, Porto Alegre: Livraria do Advogado, 2015. 


\section{A PENA}

No Ordenamento Jurídico brasileiro contemporâneo, a Pena é tida como a sanção, aplicada pelo Estado, com vistas à punir uma ação criminosa anterior e ressocializar o apenado de forma que seu caráter seja remoldado e, assim, ele tenha condições de voltar ao convívio social sem representar, de forma alguma, um perigo para os demais membros da sociedade, quer dizer, com uma garantia de que ele não irá delinquir novamente ${ }^{22}$.

\subsection{A Evolução da Pena}

No limiar de sua evolução, o conceito de "Pena" estava diretamente relacionado à ideia de vingança e, em virtude da ausência de uma administração estatal, após a ocorrência de uma ação considerada "criminosa", isto é, que contrariasse os bons costumes da época, a vítima, sua família ou, até mesmo, integrantes de seu membro social tinham o "direito" de vingar-se do criminoso. Para mais, não havia a formulação de "Justiça" que existe na atualidade, portanto, tal vingança realizava-se de maneira completamente desproporcionada com a agressão sofrida ${ }^{23}$.

Mais adiante, a adesão à lei de talião trouxe uma das primeiras formas de interferência do Estado no revide à uma agressão sofrida, pois, estabeleceu-se que, de fato, aquele que fora vítima de um crime teria o direito de revidar isso, entretanto, esta revida teria que ser proporcional à agressão sofrida, ideia esta que se resume no famoso ditado “Olho por olho, dente por dente". Deste modo, a lei de talião mostrou-se como um verdadeiro progresso na conquista de direitos do povo e um melhoramento necessário para o Sistema Penal da época, já que a ideia de proporcionalidade era, até então, inexistente ${ }^{24}$.

\footnotetext{
${ }^{22}$ GRECO, Rogério. Curso de Direito Penal: Parte geral, volume I. $19^{a}$ Edição. Niterói, RJ, Impetus, 2017.

${ }^{23}$ ESTEFAM, André. GONÇALVES, Victor Eduardo Rios. Direito Penal Esquematizado - Parte Geral. $7^{a}$ Edição, São Paulo, Editora Saraiva, 2018.

${ }^{24}$ Idem.
} 
Apesar disso, a utilização exacerbada de tal ditado fez com que se percebesse que, ao passo que uma pessoa fosse agredida e seu agressor fosse também agredido como forma de vingança, haveriam duas pessoas agredidas e, consequentemente, na maioria das vezes, deficientes. Logo, a aplicação desta lei por mais tempo resultaria na extinção de uma sociedade; comprovando, assim, que o excesso de punição não apresenta benefícios para os cidadãos, mas sim um enorme prejuízo social.

Posteriormente, tendo por base a parcela positiva da interferência, ainda que sucinta, da administração estatal no decorrer da aplicação da lei de talião, o Estado tomou para si o dever de regular, organizar e aplicar as sanções por crimes cometidos, de forma que este identificou a necessidade de estudar o crime e as circunstâncias agregadas a ele com o objetivo de fazer com que a pena fosse o mais eficaz possível e servisse a um fim social.

No entanto, nesta época, as penas aplicadas pelo Estado eram de uma crueldade evidente, pois, preocupavam-se em garantir o máximo de punição possível, sem que se atentasse à necessidade de uma ressocialização com vistas à reinserção do criminoso à sociedade, já que, devido ao excesso de punição, eram raros, quase inexistentes, casos em que o apenado sobrevivia até o final da pena. Estas penas receberam a alcunha de "Penas Cruéis" e marcaram um período de grande horror e medo por parte do povo, o que, na visão do Estado, era a forma mais viável para conter o impulso de cometer uma ação criminosa.

Neste período, a ideia de Direitos Humanos e Fundamentais ainda estava muito longe de ser desenvolvida, e a crueldade era, de certa forma, comum na maioria dos Ordenamentos ao redor do mundo; porém, por outro viés, começava-se a enxergar a necessidade de garantir direitos mais contundentes ao povo. Neste ínterim, no decorrer dos séculos XV e XVI, uma série de juristas e magistrados iniciaram o movimento que ficou conhecido como "Humanista", que desenvolveu estudos e trouxe uma nova visão acerca do indivíduo delituoso, de forma que este começava a ser visto como um humano $\mathrm{e}$, para atender às necessidades de sua natureza, diferente da maneira como eram tratados antes - como seres inferiores, indignos de qualquer regalia social ${ }^{25}$.

\footnotetext{
${ }^{25}$ ESTEFAM, André. GONÇALVES, Victor Eduardo Rios. Direito Penal Esquematizado - Parte Geral. $7^{\mathrm{a}}$ Edição, São Paulo, Editora Saraiva, 2018.
} 
Isto posto, a pena teve que passar por um processo de humanização, o que trouxe transformações responsáveis por mudar a antiga situação de detentos sucumbindo antes mesmo de finalizar o período de detenção e fazendo com que estes voltassem ao convívio social mediante o cumprimento da sanção penal. Destarte, surgiu a necessidade de fazer com que a pena atendesse a mais um fim: a ressocialização; para isso, o Estado precisaria garantir aos detentos todas as condições básicas, precisas para que este vivesse com dignidade e bem-estar, o que requeria uma reestruturação completa dos Estabelecimentos Penais.

\subsection{O Desenvolvimento do Sistema Prisional}

Um dos primeiros Sistemas Prisionais de que se tem conhecimento era o Pensilvânico ou Celular, diante do qual os apenados deveriam ficar reclusos em celas individuais, sem direito a visitas e sem proibidos de trabalhar. Ademais, como forma de ressocialização da época, impunha-se aos apenados a leitura da Bíblia, com o objetivo forma de fazer com que eles se arrependessem de sua ação criminosa e remoldassem seu caráter conforme os ensinamentos do Livro Sagrado. Certamente, tal sistema era demasiadamente rígido e não cumpria seu papel de punir e ressocializar o criminoso, pois, após passar tanto tempo sem ter contato com outras pessoas, é fato que a maioria, se não todos, desenvolvia algum distúrbio mental que os impedia de conviver socialmente e era visto pela sociedade como uma punição divina.

Mais adiante, percebendo que a rigidez do modelo anterior inviabilizava a realocação do apenado na sociedade, desenvolveu-se o Silent System, onde os detentos ainda não possuíam o direito de ter visitas e ainda se alocavam em celas individuais, todavia, já tinham momentos de convivência entre si e tinham o direito de trabalhar, uma vez que eram enxergados como mão-de-obra; resultando, assim, na estrutura de um rigor moderado em comparação ao modelo anterior. Entretanto, o nome dado a tal sistema vem justamente do fato de que, mesmo convivendo com outros detentos e com agentes penitenciários, os apenados eram proibidos de se falar, isto é, o silêncio era exigido a todo momento ${ }^{26}$.

\footnotetext{
${ }^{26}$ Idem.
} 
Posteriormente, desenvolvendo ainda mais a ideia de ressocialização, concebeuse a ideia do Sistema Progressivo, com o objetivo de reinserir o indivíduo na sociedade pouco a pouco, de maneira que os detentos passavam por fases diferentes e a cada uma dessas havia uma redução da vigilância sobre o apenado. Este sistema é adotado atualmente no Brasil, não com os mesmos moldes do momento de sua elaboração, mas sim de forma mais estudada e desenvolvida, onde os detentos passam pelo Regime Fechado, Semi-aberto e Aberto.

Porém, apesar das melhorias do sistema, não há de se negar que ele não vem cumprindo com seu papel de ressocializador, pois, os detentos acabam passando para a fase com menos vigilância sem que haja um real estudo de seu caráter e de sua personalidade, fazendo com que indivíduos perigosos voltem ao convívio social e continuem delinquindo. Por conseguinte, evidencia-se que este sistema carece de uma reestruturação, não de forma que se excluíssem os diferentes regimes, mas de forma que fosse mais difícil passar de um regime mais gravoso para um mais moderado.

\subsection{A Pena na Atualidade: As Funções da Pena}

Com o objetivo de conferir uma maior efetividade à Pena, o Direito Penal brasileiro elencou, por meio do artigo 59 do Código Penal bem como da Lei de Execução Penal, duas funções para esta, sendo elas a função punitiva, por meio da qual seria demonstrada a reprovação da sociedade para com a ação criminosa cometida, e a função ressocializadora, diante da qual o apenado teria seu caráter remoldado de forma que este não voltasse a delinquir e, deste modo, novas ações criminosas estariam sendo prevenidas e evitadas.

A primeira função da Pena - a função punitiva - assegura que o Estado, que é detentor do jus puniendi, isto é, o único legitimado para penalizar alguém criminalmente, aplicará uma sanção com o objetivo de fazer com que o criminoso entenda que sua ação anterior foi incorreta e perceba que aquela punição só está acontecendo com ele por conta de seu erro, portanto, caso este aja de forma correta ele não terá que passar por aquilo novamente.

Tal função é aplicada, na maioria das vezes, por meio da supressão temporária da liberdade do indivíduo delituoso, o que por si só não caracteriza um desrespeito aos 
Direitos Fundamentais, uma vez que a própria natureza destes permite que sejam relativizados. Ademais, também não é prejudicial aos preceitos do Estado Democrático de Direito, pois mesmo em meio ao cárcere um indivíduo permanece sendo cidadão ${ }^{27}$ e, assim, conserva seus direitos sociais, embora o exercício destes tenha que ser relativizado em razão das circunstâncias sob as quais o detento vive.

A segunda função da Pena, o foco do presente escrito, é a função ressocializadora, diante da qual o Estado tem o encargo de assegurar todos os meios e instrumentos necessários para que seja possível remoldar o caráter dos apenados com vistas a garantir que eles possam voltar a exercer sua cidadania, assim como todos os direitos advindos dela, plenamente, sem que possam ser considerados um perigo para os demais membros da sociedade. Um dos principais objetivos da ressocialização é justamente prevenir para que o apenado em questão não reincida, quer dizer, não volte a delinquir e para que outras pessoas, vendo que a sanção penal de fato é posta em prática, não delinquam.

Mais ainda, além de ser positiva para o indivíduo delituoso em si, já que o ofertaria a possibilidade de voltar a conviver em meio a sociedade e, desta vez, de uma forma mais digna do que a anterior, a ressocialização dos apenados também é benéfica à sociedade como um todo, pois, uma vez que o crime estiver sendo prevenido e evitado, o Direito Fundamental à segurança pública de todos os cidadãos estará sendo efetivado.

A Lei de Execução Penal prevê que o trabalho é um direito dos detentos e que, quando exercido, teria que atender as habilidades individuais que o apenado em questão já possui e ao desenvolvimento de novas aptidões, de forma que, futuramente, quando este pudesse voltar ao convívio social, ele pudesse se valer dessas aptidões para obter uma ocupação lícita; assim, tanto a ressocialização quanto a prevenção estariam sendo efetivadas, uma vez que, tendo a possibilidade de estar empregado de forma honesta, este indivíduo não teria o impulso de reincidir no crime.

Ademais, o trabalho deveria ser estimulado pelos administradores do Sistema Carcerário e, até mesmo, pela sociedade como um todo, já que cumprindo uma quantidade de dias de trabalho o detento teria uma remissão - um desconto - da quantidade de dias de sua pena, o que refletiria na efetivação da tão necessária ressocialização destes. Todavia, a realidade é que o trabalho não é ofertado em quase nenhum presídio brasileiro,

${ }^{27}$ GRECO, Rogério. Curso de Direito Penal: Parte geral, volume I. 19ª Edição. Niterói, RJ, Impetus, 2017. 
pois, em quase todos estes, não há estrutura para isso, fazendo com que o trabalho entre para o longo rol dos Direitos Fundamentais dos presidiários que é amplamente desrespeitado.

\subsection{O Encarceramento em Massa}

A teoria do Encarceramento em Massa veio como um dos resultados das ideias advindas do Neoliberalismo, sendo desenvolvida e tendo começado a ser aplicada nos Estados Unidos, no decorrer da década de 1980, momento em que as maiores metrópoles do país, como, por exemplo, Nova Iorque, apresentavam índices absurdos de violência, fazendo com que o Presidente Ronald Reagan adotasse uma postura de "tolerância zero" para com o crime. Mais adiante, o Brasil adotou tal teoria na década de 1990, durante o governo presidencial de Fernando Henrique Cardoso ${ }^{28}$.

Atualmente, nos moldes em que vem sendo aplicado no Brasil, o Encarceramento em Massa pode ser tido como a legitimação do "Discurso do Medo" materializando este na forma de uma intervenção estatal demasiadamente violenta, que atinge diretamente a liberdade da sociedade como um todo, de modo que os próprios cidadãos acreditam na efetivação deste como a forma mais eficaz possível para solucionar o problema da insegurança pública ${ }^{29}$. Assim, adota-se um sistema no qual encarcera-se todo e qualquer indivíduo que tenha delinquido, sem que haja uma análise com vistas a diferenciar a violência legítima da ilegítima, afastando de vez a ideia de que o Direito Penal deveria ser tido como ultima ratio, isto é, como última opção, quando nenhum dos outros ramos do Direito possuísse uma resposta adequada para a ação em questão.

Agregando a situação do Sistema Carcerário brasileiro, que está falido há décadas, à adoção do Encarceramento em Massa, que aumenta drasticamente a quantidade de indivíduos presos no regime fechado, tem-se como resultado uma situação verdadeiramente drástica, que tem como principais reflexos dentro dos presídios a superlotação carcerária e a despersonalização dos indivíduos encarcerados; já fora dos

\footnotetext{
${ }^{28}$ VELLEDA, Luciano. Paulo Serrano: Encarceramento em Massa é Medida de Controle Social do Neoliberalismo. Disponível em: https://www.redebrasilatual.com.br/cidadania/2017/01/encarceramentoem-massa-e-medida-de-controle-social-do-neoliberalismo. Acesso em 10 de dezembro de 2018. ${ }^{29}$ Idem.
} 
presídios os reflexos mais claros são a intolerância da sociedade para com os detentos, sem enxergá-los como cidadãos, e a constante insegurança pública.

\subsubsection{A Superlotação Carcerária}

Não há de se negar que a maior forma de materialização do Encarceramento em Massa dentro dos presídios se dá pela superlotação, a qual, de fato, agrava a situação dos detentos, uma vez que, se o sistema carcerário está claramente falido e não consegue garantir uma vida digna nem mesmo para a quantidade de detentos condizentes com a capacidade dos estabelecimentos penais, é fato que, com uma quantidade de apenados que supera em muito sua capacidade, não existe a possibilidade de se garantir nem mesmo o mínimo existencial ${ }^{30}$.

Atualmente, a superlotação carcerária tem três principais fatores, sendo eles a ampla quantidade de pessoas presas provisoriamente sem uma real necessidade, a parcela de indivíduos que continuam presos já tendo cumprido toda a sua pena ou tendo cumprido a fração necessária para progredir para um regime menos gravoso e o alto índice de reincidência, o qual é um claro reflexo da ineficácia da ressocialização.

Dessarte, infere-se que há a necessidade de criar uma nova política pública carcerária com vistas a reduzir largamente esses fatores, de forma que os presídios tivessem que comportar uma quantidade reduzida de apenados e, assim, os Direitos Fundamentais destes fossem mais facilmente aplicados ${ }^{31}$. Dessa forma, a ressocialização poderia ser alcançada pelos encarcerados de forma mais ampla e, consequentemente, a reincidência também seria reduzida, o que, aos poucos, solucionaria a questão da insegurança pública.

\subsubsection{A Despersonalização dos Apenados}

30 VIANA, Johnnatan Reges. A crise do sistema carcerário brasileiro. Disponível em: http://www.ambito-juridico.com.br/site/?n_link=revista_artigos_leitura\&artigo_id=12228. Acesso em 31 de dezembro de 2018.

${ }^{31}$ Idem. 
O Sistema Carcerário, de uma forma ou de outra, já retira parte da personalidade do detento desde o momento em que este adentra um presídio, fazendo com que este se desprenda de seus pertences que refletem sua personalidade e do convívio com seu meio social, o que, de fato, é necessário até certo ponto; entretanto, o problema começa quando, uma vez dentro do presídio, os indivíduos não tenham respeitados, nem mesmo, seu espaço pessoal, pois são obrigados a viver em celas superlotadas, e sua intimidade, já que tem que viver juntamente com outras pessoas sem ter o menor poder de escolha.

O fato é que, parte do processo do Encarceramento em Massa é justamente a estigmatização do indivíduo criminoso por meio de sua despersonalização, de forma que sua personalidade é destruída e, assim, a constituição de valores, uma nova moral, é completamente neutralizada. Como consequência, tem-se a adesão à chamada "Escola do Crime”, pois, os detentos, vivendo numa situação de amplo desrespeito a seus Direitos Fundamentais, chega à conclusão de que os valores do crime são muito mais facilmente materializados do que os da lei, que tanto promete e nada cumpre ${ }^{32}$.

\section{CONCLUSÃO}

À vista do exposto no presente artigo, infere-se que, de fato, o recorrente descumprimento da Lei da Execução Penal é uma das maiores evidências de que a realidade dos presídios brasileiros se apresenta em completa disparidade com a previsão legal, uma vez que os Direitos Fundamentais previstos pela Constituição e reafirmados em tal lei não tem sido devidamente efetivados nem tão pouco aplicados. Outrossim, compreende-se que não se trata de uma falha da legislação, mas sim da clara incapacidade da administração pública de efetivar as leis referentes não apenas à ressocialização, mas ao Sistema Carcerário como um todo, pois, é certo que a lei tem cumprido seu papel, tutelando os direitos dos detentos, todavia, o Estado tem falhado profundamente em aplicar esta, que, sendo demasiadamente agravada pelo encarceramento em massa, resulta em uma aplicação exagerada da função punitiva da pena enquanto a função ressocializadora não encontra efetividade.

32 LIMA, Rafaella Meire Mouzinho. A ressocialização como direito fundamental do apenado. Disponível em: https://www.jurisway.org.br/v2/dhall.asp?id_dh=19873. Acesso em 31 de dezembro de 2018. 
Mais que isso, a inefetividade da ressocialização dos apenados gera, como consequência, uma ineficácia de preceitos basilares do Estado Democrático de Direito, tais quais a cidadania, já que, uma vez que um indivíduo encarcerado não vê a materialização de seus Direitos Fundamentais nem mesmo no que corresponde ao mínimo existencial, não há como considerar-se um cidadão, pois, para ser, seria necessário que o governo se preocupasse em garantir seus direitos, o que só acontecerá mediante uma reestruturação do Sistema Carcerário como um todo, desde sua estrutura física, que não comporta a quantidade de detentos que possui nem oferece a estes direitos básicos como, por exemplo, o direito ao trabalho, até mesmo à própria adoção do Encarceramento em Massa, que claramente nunca se mostrou viável para solucionar os problemas da insegurança pública brasileira.

Por fim, compreende-se que são mais do que necessárias novas políticas públicas, com vistas à garantir a segurança fora dos presídios por meio da ressocialização dentro destes e, além disso, que objetivem mudar a visão da sociedade para com os detentos, para que estes sejam enxergados como cidadãos, merecedores de seus direitos, e não como seres inumados, que não fariam jus a um tratamento digno. Por conseguinte, haveria um amplo respeito aos Direitos Fundamentais destes, o que refletiria diretamente na segurança da sociedade como um todo. 


\section{REFERENCIAS BIBLIOGRÁFICAS}

ALVES, J. A. Lindgren. Direitos Humanos como Tema Global. $2^{a}$ Edição, São Paulo: Perspectiva, 2011.

BRASIL. Código Penal. Planalto. 07 de dezembro de 1940. Disponível em: http://www.planalto.gov.br/ccivil_03/decreto-lei/Del2848compilado.htm. Acesso em 10 de dezembro de 2018.

BRASIL. Constituição da República Federativa do Brasil. Planalto. 05 de outubro de 1988. Disponível em:

http://www.planalto.gov.br/ccivil_03/constituicao/constituicao.htm. Acesso em 04 de agosto de 2018.

BRASIL. Lei de Execução Penal. Planalto. 11 de julho de 1984. Disponível: http://www.planalto.gov.br/ccivil_03/LEIS/L7210.htm. Acesso em 10 de dezembro de 2018.

ESTEFAM, André. GONÇALVES, Victor Eduardo Rios. Direito Penal

Esquematizado - Parte Geral. $7^{\text {a }}$ Edição, São Paulo, Editora Saraiva, 2018.

GOMES, Luiz Flávio. Existe diferença entre direitos e garantias fundamentais? Disponível em: https://lfg.jusbrasil.com.br/noticias/1060567/existe-diferenca-entredireitos-e-garantias-fundamental. Acesso em 06 de dezembro de 2018.

GRECO, Rogério. Curso de Direito Penal: Parte geral, volume I. 19ª Edição. Niterói, RJ, Impetus, 2017.

LIMA, Rafaella Meire Mouzinho. A ressocialização como direito fundamental do apenado. Disponível em: https://www.jurisway.org.br/v2/dhall.asp?id_dh=19873. Acesso em 31 de dezembro de 2018.

PIRES. Anthônio. Mínimo existencial x reserva do possível. Disponível em: https://antoniopires.jusbrasil.com.br/artigos/121940660/minimo-existencial-x-reservado-possivel. Acesso em 04 de agosto de 2018.

ROMÃO, Wagner de Melo. RODRIGUES, Thiago. ONU no Século XXI. Perspectivas. $2^{\mathrm{a}}$ Edição, Desatino, 2011.

SARLET, Ingo Wolfgang. A Eficácia dos Direitos Fundamentais. 12a Edição, Porto Alegre: Livraria do Advogado, 2015.

Dignidade da pessoa humana e direitos fundamentais na Constituição

Federal de 1988. Porto Alegre: Livraria do Advogado, 2012.

O Supremo Tribunal Federal e o Direito à Vida. In Revista de Direito da Universidade de Brasília, Páginas 184 a 201, 2014.

. FIGUEIREDO, Mariana Filchtiner. Reserva do possível, mínimo existencial e direito à saúde: algumas aproximações. Revista de Doutrina da $4^{\text {a }}$ Região, Porto Alegre, n. 24, jul. 2008. Disponível em: 
<http://www.revistadoutrina.trf4.jus.br/artigos/edicao024/ingo_mariana.html>. Acesso em: 04 de dezembro de 2018.

SECCHI, L. Políticas Públicas: Conceitos, esquemas, casos práticos. $2^{\text {a }}$ Edição. São Paulo: Cengage Learning. 2013.

SILVA, Flavia Martins. Direitos Fundamentais. Disponível em: https://www.direitonet.com.br/artigos/exibir/2627/Direitos-Fundamentais. Acesso em 06 de dezembro de 2018.

SILVA, José Afonso. Estado Democrático de Direito. Revista de Direito Administrativo, Rio de Janeiro, 1988.

STRECK, Lênio Luiz; MORAIS, José Luís Bolzan. Ciência Política e Teoria Geral do Estado. $8^{\text {a }}$ Edição Porto Alegre: Livraria do Advogado, 2013.

UNIDOS PELOS DIREITOS HUMANOS. A Declaração Universal dos Direitos

Humanos. Disponível em: http://br.humanrights.com/what-are-human-rights/universaldeclaration-of-human-rights/articles-21-30.html. Acesso em: 14 de dezembro de 2018.

VAZ. Carlos. A. L. A Aplicação Limitada da Reserva do Possível. Libertas, Ouro Preto - MG, v.2 n.1, jan./jun. 2016. Páginas 245 a 273.

VELLEDA, Luciano. Paulo Serrano: Encarceramento em Massa é Medida de Controle Social do Neoliberalismo. Disponível em: https://www.redebrasilatual.com.br/cidadania/2017/01/encarceramento-em-massa-emedida-de-controle-social-do-neoliberalismo. Acesso em 10 de dezembro de 2018.

VIANA, Johnnatan Reges. A crise do sistema carcerário brasileiro. Disponível em:http://www.ambito-

juridico.com.br/site/?n_link=revista_artigos_leitura\&artigo_id=12228. Acesso em 31 de dezembro de 2018 


\title{
OS REFLEXOS DO ENCARCERAMENTO EM MASSA NA GARANTIA DOS DIREITOS FUNDAMENTAIS DOS DETENTOS
}

\author{
THE REFLECTIONS OF THE MASS JAIL IN THE GUARANTEE OF THE \\ FUNDAMENTAL RIGHTS OF DETENTIONS
}

Carolina Fontes Lima Tenório ${ }^{1}$

\begin{abstract}
RESUMO: O presente escrito objetiva analisar os reflexos que o Encarceramento em Massa causa na garantia dos Direitos Fundamentais no cumprimento da pena restritiva de liberdade em regime fechado. Destarte, vale-se de uma pesquisa bibliográfica doutrinária acerca do Direito Penal e Constitucional, com aprofundamento nos Direitos Fundamentais. Assim busca-se concluir tratando dos limites da influência do Encarceramento em Massa no papel do Estado na garantia dos Direitos Fundamentais dos detentos.
\end{abstract}

PALAVRAS-CHAVE: Sistema Penitenciário; Pena Privativa de Liberdade; Direitos Fundamentais; Encarceramento em Massa; Regime Fechado.

ABSTRACT: The present paper aims to analyze the reflexes that the Mass Imprisonment causes in the guarantee of Fundamental Rights in the fulfillment of the restrictive sentence of freedom in closed conditions. Thus, it is worth a bibliographical research of the Criminal and Constitutional Law, with a deepening of Fundamental Rights. Thus, it is sought to conclude by considering the limits of the influence of the Mass Encarceration on the role of the State in guaranteeing the Fundamental Rights of the inmates.

KEYWORDS: Penitentiary System; Prision Sentences; Fundamental Ritghs; Mass Imprisonment; Closed Conditions.

\section{INTRODUÇÃO}

Há 30 anos atrás, em 1988, a Constituição Federal vigente foi promulgada, tendo sido pautada nos ideais do Neoconstitucionalismo, movimento este que trouxe uma nova visão do Direito, principalmente do Direito Constitucional, e consagrou o Estado

\footnotetext{
${ }^{1}$ Graduanda em Direito pelo Centro Universitário Tiradentes (UNIT).
} 
Democrático de Direito como o regime político brasileiro, de forma que os Direitos Fundamentais ganharam um novo patamar, sendo investidos de maior relevância, uma vez que estes haviam sido demasiadamente suprimidos no período da Ditadura Militar, que havia se findado há pouco tempo.

Cumpre destacar que uma grande preocupação da Carta Magna de 1988 foi a garantia de uma tutela firme dos Direitos e Garantias Fundamentais, de forma que estes fossem garantidos a todos os brasileiros, sem distinção de qualquer espécie, quer dizer, mesmo os apenados devem ter seus direitos garantidos. Entretanto, a cada ano que se passa torna-se mais evidente o descaso que a administração pública tem para com a situação dos presidiários, sujeitando os detentos a (sobre)viver em condições desumanas.

Ademais, em tempos de grande violência e altos índices de criminalidade, a sociedade se vê refém de uma situação trágica, que lhe tira a liberdade em virtude da ineficácia da segurança pública e faz com que se perca a confiança na administração estatal. Consequentemente, faz com que os cidadãos acreditem que toda e qualquer regalia garantida aos detentos, por mais básica que seja, é, na verdade, uma forma de desrespeito aos membros da sociedade que foram afetados pela ação criminosa que colocou aquele indivíduo no sistema carcerário. Assim, a sociedade vê no Encarceramento em Massa uma solução para todos os problemas advindos das falhas na segurança pública.

O fato é que, a situação sob a qual os detentos têm vivido tem sido tão absurda que o Supremo Tribunal Federal entendeu a existência do chamado Estado de Coisas Inconstitucional, pois, há uma clara situação recorrente de ineficácia e ausência de aplicabilidade dos Direitos Fundamentais dos detentos, o que é demasiadamente agravado pela superlotação das casas prisionais, gerada justamente pelo Encarceramento em Massa.

Dessarte, como objetivo mor do presente artigo, busca-se a resposta para as seguintes indagações: Até que ponto o Encarceramento em Massa afeta o papel do Estado na garantia dos Direitos Fundamentais dos detentos? Será que é ele o único empecilho à efetividade e aplicabilidade de tais direitos? E é com vistas a responder à tais questionamentos que este escrito traz uma análise relativa aos Direitos Fundamentais e à Pena e a sua evolução em meio ao Estado brasileiro, bem como trata do atual panorama do Encarceramento em Massa e do recente reconhecimento do Estado de Coisas Inconstitucional. 


\section{DOS DIREITOS FUNDAMENTAIS}

Os Direitos Fundamentais são dotados de capacidade declaratória, quer dizer, declaram a existência de uma regalia legal; ademais, estão positivados constitucionalmente de forma a compreender os direitos individuais e coletivos, sociais, de nacionalidade, políticos e relacionados aos partidos políticos ${ }^{2}$. Tais direitos são de extrema relevância não apenas num contexto social, mas também num contexto humano, pois, é fato que são a positivação à nível nacional dos Direitos Humanos, devendo, consequentemente, ter sua garantia tratada sempre como maior prioridade do Estado.

\subsection{Da Carta Constitucional}

A Constituição Federal de 1988, atualmente vigente no Brasil, foi redigida ao final de uma época bastante conturbada e demasiadamente repressora para com, não apenas, os Direitos e Garantias Individuais, mas também para com todos os Direitos Fundamentais em si. Para mais, tal legislação pautou-se no fortalecimento dos Direitos e Garantias Fundamentais de forma que estes foram positivados como basilares para a o Estado Democrático de Direito brasileiro.

Outrossim, o legislador constituinte se preocupou em positivar os Direitos Fundamentais ainda no Título II da Lei Maior, de forma que sua essencialidade e sua importância ficassem bem expostas, o que se reflete, também, pelo artigo 60 da mesma, que institui os Direitos Fundamentais como uma Cláusula Pétrea, isto é, permanente, não suscetível a proposta de emenda constitucional que vise aboli-los ${ }^{3}$.

\subsubsection{Da Dignidade da Pessoa Humana}

\footnotetext{
${ }^{2}$ MORAIS, Alexandre de. Direito Constitucional. 34 Edição, São Paulo: Atlas, 2018.

${ }^{3}$ LENZA, Pedro. Direitos Humanos Fundamentais. 22 a Edição, São Paulo, Editora Saraiva, 2018.
} 
A Dignidade da Pessoa Humana expressa que todos os indivíduos devem ter garantias as prerrogativas necessárias para que se possa viver com dignidade e bem-estar ${ }^{4}$. Assim, foi estabelecida como fundamento da República Federativa do Brasil, instituída pela Lei Máxima em seu artigo primeiro, demonstrando assim sua relevância e o papel do Estado como seu garantidor.

Ademais, pode-se compreender a Dignidade da Pessoa Humana de acordo com duas acepções diversas, sendo elas a positiva e a negativa, trazendo visões bastante opostas para o termo 'dignidade', já que, enquanto a Acepção Positiva determina que a dignidade pressupõe a garantia da vida e do bem-estar, a Acepção Negativa desqualifica a importância do bem-estar, defendendo que a dignidade estaria ligada apenas à vida. Independente das condições sob as quais é vivida.

No ordenamento jurídico brasileiro, houve a preocupação em garantir que a Dignidade da Pessoa Humana fosse concebida com vistas à sua Acepção Positiva, de forma que coube ao Estado o encargo de garantir não apenas o direito à vida do povo, mas também seu bem-estar de forma universal, isto é, independente das condições sociais do indivíduo em questão ${ }^{5}$.

Assim sendo, não há de se negar que a supramencionada dignidade deve ser garantida a todos e que, realmente, sua aplicação para com todos deveria ser uma preocupação geral, todavia, o que se observa na atualidade é que a sociedade, em sua maioria, se atenta em exigir a aplicação da Dignidade da Pessoa Humana de acordo com a Acepção Positiva para aqueles que estão imersos no convívio social enquanto acredita que aqueles que vivem em cumprimento de pena são merecedores apenas de uma Acepção Negativa de tal termo.

Tal reflexo social se mostra como sendo uma contrariedade exacerbada, pois, estando sua aplicação relacionada apenas à condição humana, como seu próprio nome já diz, não deveria haver um clamor social voltado para a meritocracia, com a errônea ideia de que um indivíduo que está pagando por seus erros é menos merecedor, menos humano, que aqueles que estão em liberdade, fator este que influencia diretamente o tratamento que esses indivíduos criminosos recebem, já que, muitas vezes, os próprios agentes

\footnotetext{
4 Lemos, Eloy P. BRUgnara; Ana F. O Princípio da Dignidade da Pessoa Humana no Ordenamento Jurídico Brasileiro. Revista da Faculdade de Direito-RFD-UERJ - Rio de Janeiro, n. 31, jun. 2017. Disponível em: http://www.e-publicacoes.uerj.br/index.php/rfduerj/article/view/26639/20692. Acesso em 19 de julho de 2018.

${ }^{5}$ BARROSO, Luis Roberto. O Constitucionalismo Democrático no Brasil: Crônica de um Sucesso Imprevisto. Disponível em: http://www.luisrobertobarroso.com.br/wp-content/uploads/2012/12/Oconstitucionalismo-democratico-no-Brasil.pdf. Acesso em: 14 de julho de 2018.
} 
penitenciários partilham dessa ideia e oferecem um tratamento desrespeitoso para com os apenados, que, quase todas as vezes, os revidam com violência.

No Brasil, entende-se que a Dignidade da Pessoa Humana está intimamente ligada aos Direitos Fundamentais como um todo, todavia, é certo que tal princípio, embora basilar para a República, não deve ser aplicado em demasia, uma vez que, caso o fosse, este seria considerado um "Superprincípio"6, o que viabilizaria uma situação de detrimento dos direitos mencionados como efeito da aplicação exclusiva da Dignidade da Pessoa Humana. Em outras palavras, este princípio é de uma relevância desmedida, mas, aplicado em demasia, pode se tornar um prejuízo ás demais necessidades fundamentais para a vida e o bem-estar.

\subsection{Dos Direitos Humanos}

Os Direitos Humanos são conhecidos por serem "Normas Universais", as quais devem ser garantidas à todas as pessoas em virtude apenas de sua condição humana. Logo, tais direitos teriam a função de nortear os ordenamentos jurídicos ao redor do mundo para que estes garantissem e, de fato, aplicassem, ao menos, as prerrogativas mínimas para que as pessoas pudessem viver com dignidade ${ }^{7}$.

A preocupação mundial para com a garantia de tais direitos foi uma consequência dos horrores vividos durante a Segunda Guerra Mundial; assim sendo, para evitar que um novo quadro de guerra chegasse aos níveis de calamidade anteriormente vividos, no ano de 1948, a Organização das Nações Unidas (ONU) organizou a elaboração da Declaração Universal dos Direitos Humanos. Tal documento se apresenta como sendo um marco histórico e uma referência para a garantia dos direitos e, principalmente, das liberdades indispensáveis à vida digna.

Ainda na atualidade, a ONU perdura como grande defensora dos Direitos Humanos à nível global, o que implica no seu posicionamento quando identificada alguma situação que desrespeite esses direitos, deste modo, ela sempre atua cobrando providências quando há alguma situação de irregularidade catastrófica nos presídios

\footnotetext{
${ }^{6}$ SARLET, Ingo Wolfgang. Dignidade da pessoa humana e direitos fundamentais na Constituição Federal de 1988. 10ª Edição, Porto Alegre: Livraria do Advogado, 2015.

7 ALVES, J. A. Lindgren. Direitos Humanos como Tema Global. 4 a Edição, São Paulo: Perspectiva, 2011;
} 
brasileiros, como já fez, por exemplo, em 2017, ao cobrar medidas contra a violência nos presídios brasileiros ${ }^{8}$.

Os Direitos Humanos serviram como um verdadeiro referencial histórico e, também, como base para a concepção dos Direitos Fundamentais brasileiros, de forma que estes são, basicamente, a positivação desses em esfera nacional. Não obstante, cabe ressaltar que, além dos Direitos Humanos propriamente ditos, uma grande referência para a elaboração dos direitos basilares brasileiros foi a Carta Internacional dos Direitos do Homem.

\subsubsection{Da Carta Internacional dos Direitos do Homem}

A Carta Internacional dos Diretos do Homem compreende um verdadeiro marco para a história mundial, principalmente para a luta pela liberdade e pelos direitos, em razão de que se trata de um dos primeiros documentos voltados à garantia de direitos à nível global ${ }^{9}$. Além disso, o conteúdo dessa carta, ao tempo de sua elaboração, se mostrava como um ideal à ser alcançado por todas as nações, contudo, com o passar das décadas, embora tal documento ainda seja tido como um marco, o alcance de seus ideais terminou por ser deixado de lado em meio a uma situação em que, mais importante que pensar em ideais “ilusórios”, mostra-se necessário tentar alcançar o mínimo existencial.

\subsection{Direitos Fundamentais X Garantias Fundamentais}

De fato, é fácil perceber a utilização dos termos 'Direitos Fundamentais' e 'Garantias Fundamentais' como análogos, entretanto, faz-se mister evidenciar que estes, na verdade, não possuem significados idênticos; assim sendo, a doutrina se atenta em diferenciá-los de acordo com a interpretação da norma constitucional.

Isto posto, os Direitos Fundamentais, como já fora exposto anteriormente, são dotados de um caráter declaratório, logo, tem a função de apenas declarar a existência de uma regalia legal, por outro viés, as Garantias Fundamentais são dotadas de uma natureza

\footnotetext{
${ }^{8}$ NAÇÕES UNIDAS. Brasil: ONU cobra medidas contra violência em presídios após rebelião em Manaus. Disponível em: https://nacoesunidas.org/brasil-onu-cobra-medidas-contra-violencia-em-presidios-aposrebeliao-em-manaus/. Acesso em 12 de novembro de 2018.

9 DIREITOS HUMANOS. Carta Internacional dos Direitos do Homem. Disponível em: http://www.dhnet.org.br/direitos/deconu/textos/onu1.htm Acesso em 17 de julho de2018.
} 
assecuratória, em outras palavras, elas asseguram os meios necessários para a aplicação dos direitos ${ }^{10}$.

Em vista disso, infere-se que, ainda que não sejam dotadas da mesma natureza, os Direitos e as Garantias são verdadeiramente indispensáveis à aplicação um do outro, uma vez que, tanto os direitos precisarão das garantias para serem aplicados, caso isso não tenha sido feito naturalmente, quanto as garantias necessitarão do arcabouço declaratório dos direitos para comprovar a posse da regalia requisitada.

\subsection{Eficácia X Aplicação dos Direitos Fundamentais}

Cumpre-se preciso trazer à tona a diferenciação doutrinária entre 'Eficácia' e ‘Aplicação' dos Direitos Fundamentais, visto que, assim como Direitos e Garantias, tais vocábulos são corriqueiramente utilizados como similares, o que, de fato, não são, uma vez que, a Eficácia deve ser conceituada como sendo a capacidade de gerar efeitos jurídicos conferida à uma norma legal e, em contrapartida, a Aplicabilidade se relaciona à forma como as normas são postas em prática ${ }^{11}$.

Além do mais, em consonância com os dizeres de José Afonso da Silva, uma norma somente será aplicável à medida que for eficaz, destarte, apercebe-se a correlação entre tais vocábulos e suas funções. De resto, infere-se que a situação do Encarceramento em Massa é afetada tanto pela eficácia quanto pela aplicabilidade dos Direitos Fundamentais e vice-versa.

\subsection{Da Relação entre os Direitos Fundamentais e o Cumprimento da Pena}

Os Direitos Fundamentais têm por sua função a de garantir o bem-estar de todos, independentemente de seu posicionamento social, isto é, ainda que um indivíduo esteja restrito ao cumprimento de pena em virtude de suas ações passadas, que contrariaram o texto legal, ele não pode, sob nenhuma circunstância, ser privado de seus direitos basilares.

\footnotetext{
${ }^{10}$ LENZA, Pedro. Direitos Humanos Fundamentais. 22 ${ }^{\text {a }}$ Edição, São Paulo, Editora Saraiva, 2018.

${ }^{11}$ SALET, Ingo Wolfgang. A Eficácia dos Direitos Fundamentais. 5 ed., rev., atual e amp. Porto Alegre: Livraria do Advogado, 2005.
} 
Ademais, é fato que, como defende Robert Alexy ${ }^{12}$, a própria natureza de tais direitos permite que estes sejam relativizados, todavia, no caso da relativização da liberdade como forma de punição, não seria correto atingir demais direitos que não fossem diretamente ligados à função punitiva da pena, quer dizer, direitos basilares como, por exemplo, à saúde e à segurança não podem ser relativizados como decorrência da punição por um crime.

\section{DO DIPLOMA LEGAL}

Para que seja possível discorrer sobre a Pena e o Encarceramento em Massa de forma aprofundada, faz-se necessário, primeiramente, explanar acerca da legislação brasileira que trata de questões relativas aos apenados e a seus direitos e obrigações. Dessarte, o presente escrito elenca três principais diplomas legais, sendo eles: A Constituição Federal, o Código Penal e a Lei de Execução Penal.

\subsection{A Constituição Federal}

A Constituição Federal positivada em 1988 trouxe consigo uma série de artigos que garantem direitos aos cidadãos, dando enfoque aos supramencionados Direitos Fundamentais. Em razão disso, a Lei Maior se preocupou em estabelecer que "todos são iguais perante a lei, sem distinção de qualquer natureza(...)", assim sendo, não é a condição de detento que conferiria, de alguma forma, menos dignidade ou menos direito às regalias legais de um indivíduo. Para mais, é certo que o grande rol de direitos e garantias elencados em tal legislação não exclui demais privilégios assegurados por tratados e convenções internacionais aderidos pelo Brasil, os quais também devem ser aplicados aos apenados em razão de sua simples condição humana.

Além disso, uma importante previsão da Carta Magna brasileira está positivada em seu artigo $5^{\circ}$, inciso XLVII, que estabelece que "não haverá penas: a) de morte, salvo em caso de guerra declarada, nos termos do art. 84, XIX; b) de caráter perpétuo; c) de trabalhos forçados; d) de banimento; e) cruéis", provando de forma incontestável que a pena não deve nunca extrapolar os limites do respeito, da dignidade e, principalmente, da

\footnotetext{
${ }^{12}$ ALEXY, Robert. Teoria dos Direitos Fundamentais. Tradução de Virgílio Afonso da Silva. $2^{\text {a }}$ Edição, $4^{\mathrm{a}}$ Tiragem, São Paulo: Malheiros, 2015. Título original: Theorie der Grundrechte.
} 
própria condição humana, pois isso é o mínimo que pode ser garantido para que um indivíduo aprisionado tenha a possibilidade de ser ressocializado ${ }^{13}$.

\subsection{O Código Penal}

Por ser uma legislação infraconstitucional - que está abaixo da Constituição Federal - o Código Penal tem o papel de corroborar com os direitos já garantidos pela Lei Maior. Dessa forma, o referido código determina que é papel da Administração Pública garantir que os detentos possam exercer todos os direitos fundamentais não afetados pela relativização de sua liberdade, assim como assegurar as suas garantias fundamentais.

O fato é que, neste ponto, a realidade é bem diferente da previsão legal, a qual, realmente, é correta ao focar na previsão da efetivação e da aplicabilidade dos direitos dos apenados, entretanto, como se sabe, não é o que ocorre atualmente. Ademais, uma legislação de relevada importância como o Código Penal precisa ter a maior eficácia possível, o que torna-se bastante inviável em meio a aplicação de um Encarceramento em Massa, já que a própria situação resulta em um desrespeito dos Direitos Fundamentais ${ }^{14}$.

\subsection{A Lei de Execução Penal}

A Lei de Execução Penal é um dispositivo que contem, de forma específica, os direitos e obrigações dos apenados, prevendo assim a forma de cumprimento da pena. Tal legislação tem um papel de grande importância para o Estado Democrático de Direito brasileiro, uma vez que discorre de forma exaustiva sobre a condição do apenado e, também, do Sistema Penal como um todo, não obstante tem por seu enfoque maior a efetivação da reabilitação do condenado como forma de reinserção deste na sociedade.

Neste dispositivo, são trazidos uma série de artigos que objetivam a garantia da Dignidade da Pessoa Humana do apenado no decorrer do cumprimento da pena, de forma

${ }^{13}$ BERTONCINI, Mateus Eduardo. MARCONDES, Thais Caroline. A Dignidade da Pessoa Humana e os Direitos Humanos no Sistema Prisional Brasileiro. Disponível em: http://www.publicadireito.com.br/artigos/?cod=ec1093fe1626f25b. Acesso em 09 de dezembro de 2018. ${ }_{14}$ MALlmanN, Bárbara Moreira. Violação dos Direitos dos Apenados: Uma Análise do Precário Sistema Prisional Brasileiro. https://repositorio.ufsm.br/bitstream/handle/1/11447/MONOGRAFIA\%20$\% 20 \mathrm{~B} \% \mathrm{C} 3 \% 81 \mathrm{RBARA} \% 20 \mathrm{MALLMANN} . p d f$ sequence $=1 \&$ is Allowed $=\mathrm{y}$. Acesso em 09 de dezembro de 2018 . 
que fica fácil compreender que a Lei de Execução Penal tem a função mor de restringir o jus puniendi do Estado ${ }^{15}$, para que, desta forma, a punição seja aplicada de maneira justa e sem que o indivíduo tenha sua dignidade desrespeitada.

\section{DA PENA}

A Pena pode ser conceituada como sendo a punição, imposta, pelo Estado, como forma de retribuir a ação criminosa de forma justa e condizente com a gravidade e o dano gerado pela ação ${ }^{16}$, isto é, proporcional. Esta possui um caráter preventivo, uma vez que objetiva, também, prevenir para que não ocorram novas ações criminosas, refletindo diretamente na segurança pública, uma vez que esta tem por seu objetivo mor, além de punir, ressocializar o criminoso para que este não volte a delinquir e, assim, os índices de violência sejam reduzidos.

\subsection{Das Funções da Pena}

A Pena possui duas funções primordiais, a função de punir e a função de ressocializar, em virtude disso, deve haver um direcionamento do sistema penal como um todo para que sua aplicação seja voltada à efetivação das funções da Pena, de forma que estas sejam cumpridas e, por conseguinte, o indivíduo anteriormente delituoso possa voltar ao convívio social sem representar um perigo para a segurança pública ${ }^{17}$.

\subsubsection{Da Função de Punir}

O Estado é o detentor legal do jus puniendi, quer dizer, diante de ações criminosas, ele tem o poder-dever de aplicar uma punição, a qual acontece por meio da Pena, na maioria das vezes, mediante a supressão temporária da liberdade individual ${ }^{18}$. Ainda que a liberdade seja um direito fundamental essencial à condição humana não há de se negar que apenas a sua relativização não se mostraria como um desrespeito a tais

\footnotetext{
${ }^{15}$ Idem.

${ }^{16}$ NUCCI, Guilherme de Souza. Código Penal Comentado. $18^{\text {a }}$ Edição, Editora Forense, 2018.

${ }^{17}$ ESTEFAM, André. GONÇALVES, Victor Eduardo Rios. Direito Penal Esquematizado - Parte Geral. $7^{\mathrm{a}}$ Edição, São Paulo, Editora Saraiva, 2018.

${ }^{18}$ MIRABETE, Júlio Fabbrini. FABRINI, Renato N. Manual de Direito Penal. 26 Edição, São Paulo, 2009.
} 
direitos, todavia, a realidade atual impõe aos detentos muito mais do que uma simples relativização temporária de uma regalia legal, atingindo assim uma série de privilégios basilares para a vida, tal qual, por exemplo, o direito à saúde, que é praticamente inexistente em meio ao cárcere, o que se agrava ainda mais em virtude da superlotação gerada pelo encarceramento em massa.

Essa situação configura um cenário de amplo desrespeito aos direitos fundamentais, materializado por meio do excesso da punição do Estado, uma vez que a aplicação da função punitiva da pena não poderia, de forma alguma, violar tão gravemente as condições essenciais à Dignidade da Pessoa Humana, sendo necessário que, ao punir, o Estado encontrasse um meio-termo viável entre a relativização do direito à liberdade e o respeito e a garantia dos direitos fundamentais dos detentos.

\subsubsection{Da Função de Ressocializar}

A segunda função da pena é a função de ressocializar, de endireitar o caráter do apenado como forma de evitar uma possível nova ação criminosa depois que este saísse do Sistema Carcerário ${ }^{19}$. Outrossim, a Lei de Execução Penal estabelece, ainda em seu artigo $1^{\circ}$, que, ao Estado caberia o papel de garantir os meios necessários para que a ressocialização fosse devidamente efetivada.

A principal forma de ressocializar um indivíduo que cometeu uma ação criminosa seria por meio do trabalho, o qual deveria ser voltado para as habilidades pessoais do detento e funcionaria como meio para remitir parte da pena a cada dia de trabalho, entretanto, embora legislada, essa oportunidade de trabalho é praticamente inexistente, pois não há estrutura para isso nos presídios brasileiros, e o pouco que existe ocorre de forma bastante improvisada. Assim, o que deveria ser um direito e, até mesmo, uma obrigação do condenado, tornou-se um privilégio para poucos, portanto, é inegável que a pena, nos moldes do atual estado de Encarceramento em Massa, não tem cumprido sua função ressocializadora.

\subsection{Da Evolução da Pena}

19 NASCIMEnTO, Sheila do. Direitos Humanos e o Sistema Penitenciário. Disponível em: https://www.conteudojuridico.com.br/pdf/cj032713.pdf. Acesso em 09 de dezembro de 2018. 
Ao tempo de sua origem, o significado de 'Pena' estava intimamente ligado à vingança, dessa forma, os cometedores de crimes tinham suas condutas revidadas, vingadas, por parte da vítima ou de sua família, às vezes até mesmo de seu meio social como um todo. Destarte, a pena, a vingança, acontecia de forma absurdamente desproporcionada, uma vez que não havia preocupação alguma com a aplicação da justiça.

Posteriormente, a lex talionis - ou lei de talião - surgiu como uma verdadeira evolução do "Sistema Penal" da época, uma vez que este trouxe consigo a ideia de proporcionalidade, com o famoso ditado "Olho por olho, dente por dente", defendendo que o revide à agressão sofrida deveria ser danoso ao mesmo nível que esta. Contudo, com o passar do tempo, o que se percebeu foi que tal sistema possuía uma falha muito grande, a qual abarcava o fato de, em sendo aplicado, haveriam não apenas uma, mas duas pessoas agredidas, o que inevitavelmente enfraquecia a sociedade como um todo em dobro, comprovando que a proporcionalidade sem justiça era mais prejudicial do que benéfica $^{20}$.

Até então, a pena, que, na verdade, não passava de uma vingança, era encargo daqueles que se sentiram ofendidos por uma conduta que contrariava os bons costumes da época, entretanto, ao passo que o Estado era formado, passou-se o encargo da determinação e aplicação da pena para a administração estatal, de forma que, de certo modo, a preocupação com o criminoso começava a surgir, pois, sendo o Estado o responsável pela análise do crime, haveria um terceiro imparcial para tratar da situação, o que não existia antes, já que todos os envolvidos na vingança haviam sido, ainda que de forma indireta, afetados pela conduta anterior do criminoso ${ }^{21}$.

\subsubsection{Da Humanização da Pena}

O período compreendido entre os séculos XV e XVI foi de profunda importância para o Direito Penal e, principalmente, para a pena privativa de liberdade, uma vez que diversos juristas e magistrados da época deram início ao Movimento Humanista, em razão do qual a pena passou por um processo de humanização, quando deixava-se de lado a

\footnotetext{
${ }^{20}$ ESTEFAM, André. GONÇALVES, Victor Eduardo Rios. Direito Penal Esquematizado - Parte Geral. $7^{a}$ Edição, São Paulo, Editora Saraiva, 2018.

${ }^{21}$ Idem.
} 
ideia de que os detentos eram seres inferiores, desmerecedores de qualquer respeito e garantia de bem-estar, e começava-se a aceitar que estes eram seres humanos e, devido à isso, eram tão merecedores de seus direitos fundamentais quanto os demais cidadãos ${ }^{22}$.

Dessarte, passou-se a se estudar com mais enfoque a vida no cárcere de forma que fossem analisadas as necessidades para que o indivíduo pudesse, realmente, ser punido de forma proporcional e, assim, se arrepender de seus atos criminosos e, consequentemente, remoldar seu caráter de forma a ter condições de voltar ao convívio social sem representar um perigo aos demais membros da sociedade.

\subsection{Da Pena na Atualidade}

À vista do exposto no presente tópico (3), torna-se claro que, ainda que não seja diretamente proposital, o Estado brasileiro tem claramente passado dos limites no que diz respeito a aplicação da função punitiva da Pena e tem deixado de lado aquela que deveria ser a função mais prezada pela administração do Sistema Carcerário: a ressocialização. Assim sendo, é certo que as chances de um indivíduo ser ressocializado vivendo em meio a um local onde seus direitos são demasiadamente desrespeitados é quase inexistente e, consequentemente, a possibilidade de melhorar a segurança pública fora dos estabelecimentos prisionais está cada vez mais longe e a crença dos cidadãos no mito do Encarceramento em Massa só faz crescer cada vez mais.

\section{DO ENCARCERAMENTO EM MASSA}

Boa parte da doutrina considera que o Encarceramento em Massa nada mais é que a forma mais violenta de intervenção do Estado na liberdade dos cidadãos, a qual se materializa por meio do famoso "Discurso do Medo", fazendo com que a sociedade se sinta cada vez mais acuada e acreditando na aplicação indiscriminada da pena privativa

\footnotetext{
22 ESTEFAM, André. GONÇALVES, Victor Eduardo Rios. Direito Penal Esquematizado - Parte Geral. $7^{\mathrm{a}}$ Edição, São Paulo, Editora Saraiva, 2018.
} 
de liberdade em regime fechado, isto é, acreditando que colocar um indivíduo delinquente em um presídio é a solução para os problemas das falhas na segurança pública ${ }^{23}$.

De mais a mais, constata-se que, no Brasil, começou-se a aderir a um costume de completa ausência de análise e diferenciação entre a violência legítima e a violência ilegítima, o que se apresenta pela carência de estudo do perfil do criminoso de forma individualizada, respeitando o Princípio da Individualização da Pena, com o objetivo de determinar o grau de periculosidade deste, a possibilidade de haver uma nova ação criminosa e a viabilidade/necessidade de encarcerá-lo com vistas a ressocializá-lo.

O Encarceramento em Massa se tornou uma realidade no cenário brasileiro, em razão do fato de que o Estado passou a aplicar a pena privativa de liberdade em regime fechado como a principal maneira de controle social e manutenção da ordem pública, deixando de lado o verdadeiro sentido do Direito Penal, que deveria ser utilizado sempre como ultima ratio $^{24}$, quer dizer, como a última opção, quando nenhum outro ramo do Direito tivesse uma solução adequada para o caso em questão ${ }^{25}$. Isso porque, na prática, é muito mais fácil encarcerar um indivíduo do que efetivar e aplicar os Direitos Fundamentais da sociedade, com ênfase nos direitos à segurança e à liberdade.

Assim sendo, é certo que, num Sistema Carcerário falido como o brasileiro, a aplicação do Encarceramento em Massa afeta diretamente às condições do Estado de garantir os Direitos Fundamentais dos detentos, já que, a quantidade de apenados aumenta, porém, o orçamento destinado à manutenção destes permanece o mesmo, mostrando a completa inviabilidade de se manter tal modelo no Brasil.

\subsection{Breve Histórico}

O marco inicial para a disseminação do Encarceramento em Massa na América foi, certamente, quando as ideias decorrentes do Neoliberalismo começaram a se

\footnotetext{
${ }^{23}$ SILVA, Jeferson Alexandre. Direito Penal do Equilíbrio e o Encarceramento em Massa: Um Contraponto à Aplicação do Direito Penal Brasileiro. Disponível em: http://www.ambitojuridico.com.br/site/?n_link=revista_artigos_leitura\&artigo_id=18333\&revista_caderno=3. Acesso em 10 de dezembro de 2018.

${ }^{24}$ FERREIRA, Amanda Assis. O Papel do Judiciário em Fazer Cumprir os Direitos Humanos Fundamentais dos Detentos. Disponível em: http://enpejud.tjal.jus.br/index.php/exmpteste01/article/view/424. Acesso em 10 de dezembro de 2018.

${ }^{25}$ GRECO, Rogério. Código Penal Comentado. 11ª Edição, Niterói, Editora Impetus, 2017.
} 
disseminar nos Estados Unidos no decorrer da década de 1980, durante o governo presidencial de Ronald Reagan, quando a população carcerária começou a crescer de forma demasiadamente desenfreada. Já no Brasil, a aderência às teses neoliberais e a consequente importação do conceito de Encarceramento em Massa se deu ao longo do governo do presidente Fernando Henrique Cardoso ${ }^{26}$.

Sendo assim, por volta de 1995 tal forma de encarceramento começou a ser aplicada no ordenamento jurídico brasileiro, pois, em consonância com os dizeres de Paulo Serrano, a aplicação das ideias do Neoliberalismo geraria um aprofundamento na desigualdade social e a resposta para tal obstáculo seria o encarceramento. Ademais, já que no Brasil sempre existiu uma condição de desigualdade social evidente e avantajada, o Encarceramento em Massa foi e vem sendo aplicado como um Estado de Exceção permanente, que visa o controle social por meio de uma Cultura do Medo ${ }^{27}$.

Daí em diante, a sociedade começou a acreditar piamente no Encarceramento em Massa, de forma que a adesão desse por meio do Estado brasileiro fez com que os cidadãos se voltassem cada vez mais para a ideia de vingança. Nessa conformidade, ver sujeitos sendo encarcerados em condições desumanas, com celas lotadas, muitas vezes, com mais do que o triplo da quantidade de pessoas que poderia comportar, tornou-se algo não apenas comum, mas também uma forma de enxergar no sofrimento destes a vingança "necessária" para com a ação criminosa anteriormente cometida.

\subsection{Do Encarceramento em Massa no Brasil: Realidade Contemporânea}

Tendo por base o exposto no decorrer do presente escrito até o presente tópico, é fácil chegar à conclusão de que, para alcançar a função ressocializadora da pena, é extremamente necessário que os apenados tenham seus direitos basilares não apenas respeitados, mas, também, devidamente aplicados, pois, dessa forma, estariam sendo punidos pela perda da liberdade e pela relativização de direitos, tais quais os políticos, mas, por outro lado, viveriam em um ambiente em que sua dignidade seria respeitada.

${ }^{26}$ VELLEDA, Luciano. Paulo Serrano: Encarceramento em Massa é Medida de Controle Social do Neoliberalismo. Disponível em: https://www.redebrasilatual.com.br/cidadania/2017/01/encarceramentoem-massa-e-medida-de-controle-social-do-neoliberalismo. Acesso em 10 de dezembro de 2018.

${ }^{27}$ Idem. 
Por conseguinte, seria apresentada aos detentos uma visão da convivência social adequada e, uma vez que estes vissem o quão possível é viver respeitando os direitos dos demais e tendo seus direitos respeitados e devidamente aplicados, a ressocialização seria quase que automática, sem que nada precisasse lhes ser imposto de forma violenta ou desrespeitosa.

O fato é que a situação em que os detentos são submetidos nos presídios brasileiros administrados pelo poder púbico demonstram a materialização de um completo desrespeito à positivação constitucional da Dignidade da Pessoa Humana, bem como dos Direitos Fundamentais, afinal, é certo que os detentos não estão visualizando nem a eficácia nem tão pouco a aplicação de seu mínimo existencial. Em virtude disso, os estabelecimentos prisionais se tornaram verdadeiras escolas do crime, onde os condenados veem que os ideais do crime, das facções, são facilmente materializados, enquanto a lei, que supostamente estava ao seu lado, não sai do papel, passando-lhes a noção de que é mais viável alcançar seus objetivos continuando do lado do crime do que passando para o lado da lei.

\subsection{Dos Reflexos Interno e Externo do Encarceramento em Massa: A (In)segurança}

Por óbvio que um estado de exclusão como o Encarceramento em Massa gera prejuízos tão abundantes e desmedidos quanto as condições impostas por esse; dessarte, um dos principais infortúnios advindos de tal estado é justamente a insegurança que este reproduz. Além disso, embora o supracitado mito tente acobertar isso, mediante um simples aprofundamento no estudo da situação atual do Sistema Carcerário, é simples inferir que o que acontece dentro dos presídios se reflete justamente fora deles, em meio à sociedade, logo esta que tanto se preocupa em aprisionar pessoas não enxerga como isso pode se voltar contra sua segurança.

Dentro dos presídios, o que se observa é uma situação que chegou ao nível alarmante em que, não apenas aqueles que lá trabalham, mas, também, os próprios detentos terminam por se sentir inseguros, pois, vivem sob uma iminente ameaça de revolta, a qual, por certo, seria o resultado da vivência num confinamento que não lhes garante nem mesmo as condições mínimas para viver, de um sistema que o encarcerou de forma indiscriminada quando poderiam haver diversas outras formar de aplicar uma 
penalidade legal. Demonstrando a clara fortificação da criminalidade por meio da chamada "Subcultura Carcerária"28, diante da qual os detentos abarcam a "cultura" do crime disseminada dos estabelecimentos carcerários.

Já do lado de fora dos muros dos presídios, a ineficácia da ressocialização, resultante do Encarceramento em Massa, faz com que a criminalidade cresça cada vez mais, alcançando índices absurdos, gerando uma insegurança pública por parte da sociedade. Como consequência, chega-se à uma questão discorrida desde o início deste artigo, sendo esta a crença no Encarceramento em Massa, a ideia de que, se a sociedade vive em constante insegurança fora dos estabelecimentos prisionais, nada mais justo do que fazer com que a punição dentro destes seja bastante rígida.

Não há de se negar que o Encarceramento em Massa realmente reflete negativamente na aplicabilidade dos Direitos Fundamentais dos presos em regime fechado, todavia, não é possível afirmar que ele é o único responsável por tal situação, uma vez que, a má administração do Estado, que, muitas vezes, deixa indivíduos presos sem necessidade, podendo estar em outro regime ou até cumprindo outro tipo de pena, e fazendo com que vários destes permaneçam em presídios mesmo depois que seu tempo de pena já foi cumprido, é um claro originador da ineficácia e péssima aplicabilidade dos supracitados direitos.

Outrossim, ainda que o Encarceramento em Massa fosse o único motivador destas ineficácia e inaplicabilidade, o Estado ainda seria o culpado, visto que foi ele que importou tal estado de exclusão e vem aplicando-o ao longo de um pouco mais do que duas décadas. Assim sendo, da mesma forma que este foi o responsável por originar esta situação, este deve, também, se responsabilizar pela resolução desta, de forma que, a ressocialização seja devidamente efetivada e, aos poucos, os índices de encarceramento e de criminalidade decresçam.

\section{DO ESTADO DE COISAS INCONSTITUCIONAL}

Como exposto anteriormente, as casas penitenciárias brasileiras, de forma geral, estão em uma situação de Encarceramento em Massa, o que por si só já é preocupante,

\footnotetext{
${ }^{28}$ BITENCOURT, Cezar Roberto. Tratado de Direito Penal: Parte Geral. $23^{\mathrm{a}}$ Edição. São Paulo, Saraiva, 2017.
} 
entretanto, além disso, ainda há o desrespeito generalizado às previsões legais garantidoras dos Direitos Fundamentais, que, agregado às evidentes falhas estruturais, comprova a existência do chamado Estado de Coisas Inconstitucional (ECI). Tal estado foi decretado pelo Supremo Tribunal Federal através de dois importantes julgados, sendo eles: o Recurso Especial no 592.581 e a Medida Cautelar em Arguição de Descumprimento de Preceito Fundamental (ADPF) n $n^{\circ} 347^{29}$.

O mais comum é ver casos em que documentos, materiais escritos, são determinados como sendo inconstitucionais, mas, no caso em questão, nos ECIs, é uma situação que é inconstitucionalizada. Isto foi uma novidade para o ordenamento jurídico brasileiro, a qual teve precedente na Corte Constitucional Colombiana, que utilizou o termo pela primeira vez à frente da Sentencia de Unificación (SU) no 559 de 1997, na qual constatou-se o desrespeito trivializado de direitos previdenciários de certo grupo social, quando foi declarada a inconstitucionalidade da situação na qual estes estavam inseridos $^{30}$.

Neste viés, é crucial apontar que o Estado de Coisas Inconstitucional atinge os mais diversos segmentos, o Sistema Carcerário é apenas mais um destes, no entanto, tal sistema ganha mais notoriedade em razão da gravidade da situação de desrespeito e inaplicabilidade dos Direitos Fundamentais dos detentos em tal meio. Ademais, tal conceito foi importado para o Brasil e recentemente decretado justamente pela situação do cárcere brasileiro.

\subsection{Do Contexto Atual: Estado de Coisas Inconstitucional em Meio ao Encarceramento em Massa}

Não é segredo que os presídios brasileiros estão em uma situação de completo sucateamento, o que é claramente agravado pela superlotação resultante do Encarceramento em Massa, e aponta para a evidente incapacidade da administração

\footnotetext{
${ }^{29}$ SOARES, Letícia. SANTOS, Amanda. OLIVEIRA, Marília de. O Estado de Coisas Inconstitucional no Ordenamento Jurídico Brasileiro: Uma Análise Acerca das Falhas Estruturais do Sistema Prisional em Face da Tutela Deficiente de Direitos Fundamentais como Omissão Inconstitucional. Disponível em: http://enpejud.tjal.jus.br/index.php/exmpteste01/article/view/428. Acesso em 09 de dezembro de 2018.

${ }^{30}$ Idem.
} 
pública de tutelar de forma efetiva e prática os Direitos Fundamentais dos detentos por meio de ações e políticas públicas voltadas para a função ressocializadora da pena ${ }^{31}$.

A situação do Encarceramento em Massa se tornou tão prejudicial à sociedade que o próprio Conselho Nacional de Justiça brasileiro mencionou que "o Encarceramento em Massa que vem ocorrendo no Brasil não gerou qualquer impacto positivo sobre os indicadores de violência" ${ }^{32}$, quer dizer, um estado de exclusão adotado pelo governo que fracassou de maneira tão absurda que se chegou ao ponto de um conselho nacional admitir isso.

Por conseguinte, entende-se que o cerne do reflexo do Encarceramento em Massa na garantia dos Direitos Fundamentais dos detentos está centrado, atualmente, no Estado de Coisas Inconstitucional, uma vez que, este apresenta justamente o limite da influência da superlotação dos presídios na aplicabilidade de tais direitos, pois determina que esta é apenas um dos fatores que pode levar à inconstitucionalização de uma situação, já que, além disso, também é preciso que se evidencie a incapacidade da administração pública de tutelar tais direitos ${ }^{33}$, algo claramente presente do Sistema Carcerário brasileiro.

Assim, compreende-se que a superlotação dos estabelecimentos prisionais não gera novos problemas, ela apenas agrava situações preexistentes. O problema maior é que a superlotação se tornou uma crise permanente e ela, assim como o Encarceramento em Massa como um todo, não se trata de uma questão penal nem mesmo administrativa, mas sim política, já que foram as inclinações políticas da década de 90 que levaram à adoção de tal estado de exclusão. Destarte, para que o contexto atual seja melhorado, a solução tem que vir da política.

\section{CONCLUSÃO}

\footnotetext{
${ }^{31}$ SOARES, Letícia. SANTOS, Amanda. OLIVEIRA, Marília de. O Estado de Coisas Inconstitucional no Ordenamento Jurídico Brasileiro: Uma Análise Acerca das Falhas Estruturais do Sistema Prisional em Face da Tutela Deficiente de Direitos Fundamentais como Omissão Inconstitucional. Disponível em: http://enpejud.tjal.jus.br/index.php/exmpteste01/article/view/428. Acesso em 09 de dezembro de 2018.

${ }^{32}$ BRASIL. Conselho Nacional de Justiça. Informativo da Rede Justiça Criminal: Os números da justiça criminal no $\quad$ Brasil. $2016 . \quad$ Disponível http://www.cnj.jus.br/files/conteudo/arquivo/2016/02/b948337bc7690673a39cb5cdb10994f8.pdf. Acesso em 10 de dezembro de 2018.

${ }^{33}$ CAMPOS, Carlos Alexandre de Azevedo. O Estado de Coisas Inconstitucional e o Litígio Estrutural. 2015. Disponível em: https://www.conjur.com.br/2015-set-01/carlos-campos-estado-coisasinconstitucional-litigio-estrutural. Acesso em 10 de dezembro de 2018.
} 
À vista do exposto no decorrer do presente artigo, infere-se que, a maior prova da completa ineficácia do Encarceramento em Massa foi a recente decretação de Estado de Coisas Inconstitucional. Assim, é preciso consolidar a ideia de que o Encarceramento em Massa não se apresenta, nem nunca se apresentou, como uma solução viável, nem mesmo possível, para a redução dos altos índices de criminalidade; para tanto, o primeiro grande desafio é de cunho social e requer uma conscientização do povo, por meio de ações governamentais e políticas públicas voltadas à redução da criminalidade e consequente segurança pública.

Outrossim, faz-se necessário que os cidadãos compreendam que as condições sob as quais os indivíduos apenados vivem é importante para os cidadãos como um todo e deve respeitar os preceitos basilares de nosso Estado, tais quais a garantia da Dignidade da Pessoa Humana e os Direitos e Garantias Fundamentais, uma vez que, a segurança interna dos presídios se refletirá, num momento futuro, no ambiente externo, isto é, fora dos muros das casas presidiárias, em meio à sociedade. Dessarte, deve haver uma maior preocupação social com a garantia dos direitos dos detentos, que devem ser vistos com a relevância que de fato tem e não como privilégios desnecessários.

Por fim, conclui-se que, os presídios não mudam o caráter dos detentos, pois para isso, seria necessária uma mudança do meio social como um todo. Isto posto, a melhor forma de fazer com que a sociedade desacredite no mito do Encarceramento em Massa seria por meio de uma real compensação do criminoso ao ofendido, pois, assim, os cidadãos teriam como ver aquele indivíduo como um ser humano, merecedor de uma vida digna, com seus direitos devidamente efetivados e, principalmente, aplicados. 


\section{REFERÊNCIAS BIBLIOGRÁFICAS}

ALEXY, Robert. Teoria dos Direitos Fundamentais. Tradução de Virgílio Afonso da Silva. $2^{\mathrm{a}}$ Edição, $4^{\mathrm{a}}$ Tiragem, São Paulo: Malheiros, 2015. Título original: Theorie der Grundrechte.

ALVES, J. A. Lindgren. Direitos Humanos como Tema Global. $4^{\text {a }}$ Edição, São Paulo: Perspectiva, 2011.

BARROSO, Luis Roberto. O Constitucionalismo Democrático no Brasil: Crônica de um Sucesso Imprevisto. Disponível em: http://www.luisrobertobarroso.com.br/wpcontent/uploads/2012/12/O-constitucionalismo-democratico-no-Brasil.pdf. Acesso em: 14 de julho de 2018 .

BERTONCINI, Mateus Eduardo. MARCONDES, Thais Caroline. A Dignidade da Pessoa Humana e os Direitos Humanos no Sistema Prisional Brasileiro. Disponível em: http://www.publicadireito.com.br/artigos/?cod=ec1093fe1626f25b. Acesso em 09 de dezembro de 2018.

BITENCOURT, Cezar Roberto. Tratado de Direito Penal: Parte Geral. $23^{\text {a }}$ Edição. São Paulo, Saraiva, 2017.

BRASIL. Código Penal. Planalto. 07 de dezembro de 1940. Disponível em: http://www.planalto.gov.br/ccivil_03/decreto-lei/Del2848compilado.htm. Acesso em 10 de dezembro de 2018.

BRASIL. Conselho Nacional de Justiça. Informativo da Rede Justiça Criminal: Os números da justiça criminal no Brasil. 2016. Disponível em:

http://www.cnj.jus.br/files/conteudo/arquivo/2016/02/b948337bc7690673a39cb5cdb109 94f8.pdf. Acesso em 10 de dezembro de 2018.

BRASIL. Constituição da República Federativa do Brasil. Planalto. 05 de outubro de 1988. Disponível em:

http://www.planalto.gov.br/ccivil_03/constituicao/constituicao.htm. Acesso em 04 de agosto de 2018.

BRASIL. Lei de Execução Penal. Planalto. 11 de julho de 1984. Disponível: http://www.planalto.gov.br/ccivil_03/LEIS/L7210.htm. Acesso em 10 de dezembro de 2018.

CAMPOS, Carlos Alexandre de Azevedo. O Estado de Coisas Inconstitucional e o Litígio Estrutural. 2015. Disponível em: https://www.conjur.com.br/2015-set01/carlos-campos-estado-coisas-inconstitucional-litigio-estrutural. Acesso em $10 \mathrm{de}$ dezembro de 2018.

DIREITOS HUMANOS. Carta Internacional dos Direitos do Homem. Disponível em: http://www.dhnet.org.br/direitos/deconu/textos/onu1.htm Acesso em 17 de julho de 2018. 
ESTEFAM, André. GONÇALVES, Victor Eduardo Rios. Direito Penal Esquematizado - Parte Geral. $7^{\text {a }}$ Edição, São Paulo, Editora Saraiva, 2018.

FERREIRA, Amanda Assis. O Papel do Judiciário em Fazer Cumprir os Direitos Humanos Fundamentais dos Detentos. Disponível em: http://enpejud.tjal.jus.br/index.php/exmpteste01/article/view/424. Acesso em $10 \mathrm{de}$ dezembro de 2018.

GRECO, Rogério. Código Penal Comentado. $11^{\text {a }}$ Edição, Niterói, Editora Impetus, 2017.

LENZA, Pedro. Direitos Humanos Fundamentais. 22 ${ }^{a}$ Edição, São Paulo, Editora Saraiva, 2018.

LEMOS, Eloy P. BRUGNARA; Ana F. O Princípio da Dignidade da Pessoa Humana no Ordenamento Jurídico Brasileiro. Revista da Faculdade de DireitoRFD-UERJ - Rio de Janeiro, n. 31, jun. 2017. Disponível em: http://www.epublicacoes.uerj.br/index.php/rfduerj/article/view/26639/20692. Acesso em 19 de julho de 2018.

NAÇÕES UNIDAS. Brasil: ONU cobra medidas contra violência em presídios após rebelião em Manaus. Disponível em: https://nacoesunidas.org/brasil-onu-cobramedidas-contra-violencia-em-presidios-apos-rebeliao-em-manaus/. Acesso em $12 \mathrm{de}$ novembro de 2018.

NASCIMENTO, Sheila do. Direitos Humanos e o Sistema Penitenciário. Disponível em: https://www.conteudojuridico.com.br/pdf/cj032713.pdf. Acesso em 09 de dezembro de 2018.

NUCCI, Guilherme de Souza. Código Penal Comentado. $18^{\mathrm{a}}$ Edição, Editora Forense, 2018.

MALLMANN, Bárbara Moreira. Violação dos Direitos dos Apenados: Uma Análise do Precário Sistema Prisional Brasileiro. Disponível em: https://repositorio.ufsm.br/bitstream/handle/1/11447/MONOGRAFIA\%20$\% 20 \mathrm{~B} \% \mathrm{C} 3 \% 81 \mathrm{RBARA} \% 20 \mathrm{MALLMANN}$. pdf? sequence=1\&isAllowed=y. Acesso em 09 de dezembro de 2018.

MIRABETE, Júlio Fabbrini. FABRINI, Renato N. Manual de Direito Penal. 26a Edição, São Paulo, 2009.

MORAIS, Alexandre de. Direito Constitucional. 34 Edição, São Paulo: Atlas, 2018.

SALET, Ingo Wolfgang. A Eficácia dos Direitos Fundamentais. 5 ed., rev., atual e amp. Porto Alegre: Livraria do Advogado, 2005.

Dignidade da pessoa humana e direitos fundamentais na Constituição

Federal de 1988. 10ª Edição, Porto Alegre: Livraria do Advogado, 2015. 
SILVA, Jeferson Alexandre. Direito Penal do Equilíbrio e o Encarceramento em Massa: Um Contraponto à Aplicação do Direito Penal Brasileiro. Disponível em: http://www.ambito-

juridico.com.br/site/?n_link=revista_artigos_leitura\&artigo_id=18333\&revista_caderno $=3$. Acesso em 10 de dezembro de 2018 .

SOARES, Letícia. SANTOS, Amanda. OLIVEIRA, Marília de. O Estado de Coisas Inconstitucional no Ordenamento Jurídico Brasileiro: Uma Análise Acerca das Falhas Estruturais do Sistema Prisional em Face da Tutela Deficiente de Direitos Fundamentais como Omissão Inconstitucional. Disponível em:

http://enpejud.tjal.jus.br/index.php/exmpteste01/article/view/428. Acesso em 09 de dezembro de 2018.

VELLEDA, Luciano. Paulo Serrano: Encarceramento em Massa é Medida de Controle Social do Neoliberalismo. Disponível em:

https://www.redebrasilatual.com.br/cidadania/2017/01/encarceramento-em-massa-emedida-de-controle-social-do-neoliberalismo. Acesso em 10 de dezembro de 2018. 


\title{
PRIVATIZAÇÃO DAS PRISÕES: OS POSSÍVEIS REFLEXOS NAS POLÍTICAS DE ENCARCERAMENTO EM MASSA NO BRASIL
}

\author{
PRIVATIZATION OF PRISONS: THE POSSIBLE REFLECTIONS IN MASS \\ PACKAGE POLICIES IN BRAZIL
}

\author{
Jéssica Rodrigues de Melo ${ }^{1}$ \\ Orientadores: Prof $^{\circ}$. Me. Bruno Cavalcante Leitão \\ Santos $^{2}$ \\ Prof $^{\mathrm{o}}$. Dr. Hugo Leonardo Rodrigues Santos ${ }^{3}$
}

\begin{abstract}
RESUMO: O presente trabalho almeja analisar a atual conjuntura do sistema penitenciário como reflexo do sistema econômico político adotado e, por meio dos dados fornecidos pelos órgãos públicos, demonstrar o alvo preferencial de aprisionamento, bem como a situação de falência das prisões brasileiras, na qual é comum a violação de direitos básicos ao ser humano, a superpopulação e a deficiência na prestação dos serviços. Sob a justificativa da escassez de recursos públicos e dos precários serviços prestados nos estabelecimentos penais, a privatização permeia a esfera prisional, com o discurso de estar alicerçada na efetividade, eficiência e na menor onerosidade. Valendo-se das experiências de outros países, com o foco nos Estados Unidos, muitas críticas e pontos favoráveis são apontados pela literatura. Um dos grandes problemas descritos pelos opositores da privatização é a tendência encarceradora em virtude do objetivo lucrativo da atividade entregue ao empreendedor privado, que perpetuaria a superpopulação carcerária sem observar as reais finalidades da pena.
\end{abstract}

PALAVRAS-CHAVE: Sistema penitenciário. Encarceramento em massa. Privatização prisional. Política criminal.

\footnotetext{
ABSTRACT: This study aims to analyze the current situation of the prison system as a reflection of the political economical system adopted and, through data provided by public agencies, demonstrate the preferential target of imprisonment, as well as the bankruptcy situation of Brazilian prisons, in which it is common the violation of basic human rights, overpopulation and deficiency in the provision of services. Under the

${ }^{1}$ Graduanda no curso de Direito pelo Centro Universitário CESMAC - Maceió/AL. Membro Associado do Instituto Brasileiro de Ciências Criminais (IBCCRIM) com a matrícula 35355. Contato: jessica.meloo@hotmail.com.

${ }^{2}$ Doutorando em Direito (PUC/RS). Mestre em Direito Público (UFAL). Especialista em Direito Penal e Processo Penal (UCDB). Professor de Direito Penal do Centro Universitário Cesmac e da FAMA. Coordenador Adjunto (seccional Alagoas) do Instituto Brasileiro de Ciências Criminais - IBCCRIM; Coordenador do Laboratório de Ciências Criminais de Maceió- AL. Pesquisador do Grupo "Direito, contemporaneidade e transformações sociais" junto ao CNPq CESMAC - FEJAL. Contato: brunoleitão.adv@hotmail.com

${ }^{3}$ Doutor e mestre em Direito Penal pela UFPE; Pós-graduação em Direito Penal e Processual Penal pela ESMAPE; Professor no CESMAC; Coordenador adjunto do Instituto Brasileiro de Ciências Criminais IBCCRIM, em Alagoas. Membro da AIDP. Contato: hugoleosantos@yahoo.com.br
} 
argument of the scarcity of public resources and the precarious services provided in penal establishments, privatization permeates the prison sphere, with the discourse of being based on effectiveness, efficiency and the least onerousness. Drawing on the experiences of other countries, with the focus on the United States, many criticisms and favorable points are pointed out by literature. One of the major problems described by the privatization opponents is the incarceration tendency because of the lucrative objective of the activity delivered to the private entrepreneur, which would perpetuate the overcrowding in prison without observing the actual purposes of the penalty.

KEYWORDS: Penitentiary system. Mass imprisonment. Prison privatization. Criminal policy.

\section{INTRODUÇÃO}

Essa pesquisa visa contribuir para a explanação do atual cenário do grande encarceramento em massa, as suas características, implicações e as soluções apresentadas ao instituto em crise da pena privativa de liberdade. Esse tipo de sanção tem sido aplicada com predileção pelo Estado e, em virtude disso, a situação encontrada nos cárceres brasileiros é considerada sub-humana. Para agravar ainda mais a situação, o Brasil caminha na contramão dos países que lideram os rankings de encarcerados, pois enquanto estes apresentam reduções de pessoas presas, Salo de Carvalho aponta que o Brasil demonstra índices de presos que superam o próprio crescimento populacional. Diante dessa realidade e de inúmeras denúncias de violação dos direitos humanos, surge mecanismos para sanar a falta de recursos na área, deficiências na prestação dos serviços e a escassez de vagas, sendo esse o palco para a intervenção privada no sistema penal.

A participação privada na esfera prisional ocorre em diferentes graus de interferência, que vai desde a privatização total, comum nos Estados Unidos até às gestões compartilhadas, semelhantes ao modelo adotado pela França. Esse último modelo serviu de inspiração para o Brasil e a sua primeira experiência ocorreu em 1999, no estado do Paraná. Embora a terceirização tenha sido interrompida em 2006, a prática se espalhou para outros Estados da Federação, como Santa Catarina, Espírito Santo, Bahia, Ceará e Amazonas. Nesses contratos havia o compartilhamento da gestão prisional, cabendo ao Estado à construção do estabelecimento penal, a direção e a segurança externa do presídio, e sendo de responsabilidade da empresa privada toda a operacionalização, 
incluindo o fornecimento das assistências, alimentação, vestuário e a segurança interna, além das atividades que promovem a ressocialização do reeducando, por exemplo, o estudo e o trabalho.

Outro modelo adotado no Brasil nesse contexto de efetividade, mas em menor proporção, é a Parceria Público-Privada, que somente foi concretizada no Estado de Minas Gerais. Nesse modelo, o empreendedor privado assume também o projeto arquitetônico, o financiamento, a construção e a gestão do estabelecimento por um período maior de contrato.

O estudo tem como hipótese principal a ideia de que a interferência do particular na execução penal, pautada numa pretensão capitalista neoliberal, que se compromete com a obtenção de lucro, teria por principal interesse a replicação do grande encarceramento para garantir o incremento das verbas repassadas pelo Estado. Além do mais, essa prática ameaçaria as frágeis finalidades da pena, pois os agentes privados estariam condicionados a enxugar custos em razão da obtenção de lucro, não prezando pela garantia dos direitos inerentes ao preso, e, consequentemente, não visando a sua ressocialização.

A metodologia adotada para a consecução do objetivo do estudo foi a do tipo teórica, com base no método dedutivo, por meio de revisão da literatura. Os referenciais teóricos utilizados foram encontrados em publicações em artigos científicos, periódicos, livros e revistas. Além disso, a pesquisa foi realizada através no método científico, fazendo uma análise qualitativa para a compreensão dos fenômenos do sistema penitenciário brasileiro.

Esse artigo foi estruturado em três capítulos. O primeiro capítulo expõe algumas causas que deram origem a um movimento de encarceramento no Brasil, com base no modelo socioeconômico adotado e no seu processo de formação, cujos resultados promoveram desequilíbrios sociais. Além disso, dados foram expostos para delinear as características desse fenômeno, bem como a solução encontrada pelo Estado para prover a execução penal. O segundo capítulo faz um breve histórico do surgimento da intervenção do particular nas prisões no mundo e no Brasil, além de diferenciar as modalidades adotadas, os argumentos pró-privatização e as críticas à adoção dos modelos. O terceiro e último capítulo versa sobre os resultados de países que há mais tempo vivenciam a privatização, com o enfoque dos Estados Unidos, um dos pioneiros dessa prática, além de alguns raros resultados de experiências brasileiras. 


\section{O GRANDE ENCARCERAMENTO}

O sistema penitenciário, em sua origem mais remota, moldou-se conforme o modelo político-econômico adotado. Antigamente, a prisão não era tida como pena, mas como um local de deter, provisoriamente, os criminosos, até que a sua verdadeira pena fosse sentenciada, como a morte, penas corporais, trabalhos forçados ou perda de bens. Dessa forma, a privação era apenas um meio e não a pena fim. A partir da mudança de paradigma no século XVIII e a inserção do modelo capitalista de produção, originou-se a pena privativa de liberdade (GUEDES, 2010).

A penalidade neoliberal confirma a onipotência do Estado no domínio restrito da manutenção da ordem pública, na qual é necessário o reforço em matéria de segurança, que comumente é relegada somente a dimensão criminal. Essa penalidade se apresenta de forma ainda mais sedutora quando é aplicada em países com fortes desigualdades sociais, desprovidos de mecanismos capazes de amortecer os choques dessas disparidades, que alimentam o crescimento da violência criminal, como é o caso brasileiro (WACQUANT, 1999). O Estado se torna garantidor de direitos fundamentais das classes elitizadas, restando para a fatia marginalizada da sociedade a repressão estatal. Por óbvio, essa estrutura de dominação camufla a exclusão do modelo capitalista, no qual afasta os pobres, marginalizados e criminosos.

O encarceramento em massa é um fenômeno crescente em virtude da predileção do sistema penal pela prisão como resposta à criminalidade, salientando o seu exponencial crescimento a partir da década de 1980. Momento no qual, vários teóricos da política criminal estavam escrevendo sobre a tendência para o declínio da prisão e a busca por instrumentos de controle sociais mais variados. Contudo, ocorreu o movimento inverso, no qual o direito penal foi e é utilizado em prima ratio, desencadeando o aumento significativo de encarcerados e a aplicação indiscriminada da pena privativa de liberdade (ABRAMOVAY, 2010). O vertiginoso aumento da "clientela" do sistema penitenciário é salientado por Santos (2015):

Nos últimos anos, é possível se verificar um aumento vertiginoso da utilização da prisão, como pretensa solução dos problemas sociais, com uma consequente massificação dos índices de encarceramento. Somente para ilustrar esse dado, nos seis países americanos mais populosos (o Brasil incluído nesse rol), o crescimento da população 
carcerária foi superior a $80 \%$, nos últimos quinze anos do século $\mathrm{XX}$. Essa tendência é bastante acentuada no sistema criminal brasileiro, no qual a população carcerária cresceu enormemente, em um período curto de tempo (SANTOS, 2015, p. 81).

Devido a esse intenso incremento da população aprisionada, os cárceres brasileiros guardam as piores mazelas de um sistema que está em colapso por seus estabelecimentos superlotados e carentes de investimentos estatais, com intoleráveis condições de higiene, espaço e alimentação. A pena privativa de liberdade vive uma crise, assistências básicas são negadas e cuidados elementares à vida são negligenciados, sem falar no caos decorrente da falta de separação entre as categorias de criminosos e a ociosidade de grande parte dos reeducandos por não ter trabalho e programas educacionais (WACQUANT, 1999).

Em sua pesquisa, Cristina Guedes destaca:

Verifica-se, portanto, que há uma total precarização do sistema prisional. Os presos vivem em condições insalubres, sofrem com a superlotação dos presídios, com a alimentação insuficiente e de má qualidade e com a falta da assistência jurídica, sendo que muitos continuam presos mesmo depois de terminada a pena, ou cumprem-na em regime fechado apesar de terem direito a livramento condicional ou a cumpri-la em regime mais brando (GUEDES, 2010, p.68).

Decerto, esse movimento de crescimento se apresenta de maneira incoerente, uma vez que não condiz com medidas que, em tese, promoveriam o desencarceramento. Como exemplo dessas medidas, cita-se a Lei 9.099/95, que despenaliza os crimes de menor potencial ofensivo e a Lei 12.403/11, cuja modificação do Código de Processo Penal torna a prisão processual uma excepcionalidade e não a regra dos processos criminais (SANTOS, 2017, no prelo).

De forma pertinente, Carvalho (2010) destaca que esse fenômeno é fruto das mudanças legislativas que ocorreram, principalmente, entre o final do século XX e início do século XXI, levando em consideração a tendência punitivista e proibicionistas dos operadores jurídicos. Ressalta que, a curva crescente do número de encarcerados no país ultrapassa os $100 \%$ só na última década, cujo crescimento populacional foi de apenas $15 \%$ no mesmo lapso temporal. Em virtude desse incremento da população presa, o índice de custodiados por 100 mil habitantes subiu de 137,08 em 2000 para 249,78 em 2009, indicando uma tendência global de encarcerar mais que o próprio crescimento populacional. 
Segundo Mesquita (2017), essa conjuntura prisional também é um reflexo do modelo socioeconômico adotado pelo Brasil no seu processo de formação, já que houve o favorecimento de uma pequena parte hegemônica da sociedade em detrimento dos demais, bem como a urbanização desestruturada e acelerada, que ocasionou grandes desequilíbrios sociais, cuja solução não se deu por políticas criminais críticas, mas sim por um direito penal utilizado sempre em primeiro lugar, que segregou ainda mais esses indivíduos. Isso foi ainda mais reforçado pelo espetáculo da mídia, que disseminou o medo e a ideia de que punir através da privação de liberdade é a resposta aos crimes cometidos. Porém, não há o feedback na diminuição da criminalidade, o que ocorre é tão somente o aumento de pessoas enclausuradas.

Os reflexos dessa forte tendência encarceradora geram estigmas e o "favorecimento de um ambiente criminógeno" (PINHEIRO, 2016, p. 602), bem como a criminalização da pobreza, delineando muito bem os "bodes expiatórios” (ZAFFARONI, 2013, p. 136) e os inimigos da nação, concretizando a teoria do etiquetamento social (Labelling approach), na qual há um perfil de criminoso introjetado no imaginário das pessoas. Assim, o Estado assume uma postura punitiva exacerbada, pautada em filtros seletivos, que preza pela segurança e termina por não mais valorizar o direito à liberdade do indivíduo.

Diante disso, dados do Conselho Nacional de Justiça (CNJ), em 2014, demonstram que o Brasil ocupa a quarta posição no ranking dos 10 países com maior população prisional, com 563.526 presos e 711.463 , quando somados os que estão em prisão domiciliar. Contudo, o sistema prisional possui apenas 357.219 vagas para dar custódia aos presos. Para agravar ainda mais os números alarmantes da superlotação carcerária, em decorrência de uma criminologia midiática, que dissemina a sensação de insegurança, o discurso de impunidade e a cultura punitivista de encarceramento (ZAFFARONI, 2013), cerca de 40\% são presos provisórios, isto é, não foram condenados definitivamente, ferindo o princípio constitucional e processual da inocência.

O Brasil caminha na direção oposta quando se equipara com os países que lideram as três primeiras posições nesse ranking. Segundo dados, no lapso temporal entre 2008 e 2014, houve um aumento de pessoas presas de 33\% no país, enquanto que os Estados Unidos, China e Rússia alcançaram reduções de $8 \%$, 9\% e 24\%, respectivamente (MESQUITA, 2017). Essa superpopulação das prisões ocorre, principalmente, pelo grande encarceramento de crimes não violentos. Conforme resultados do INFOPEN 
(BRASIL, 2014), 46\% dos presos cometeram crimes contra o patrimônio, $28 \%$ foram presos por causa do tráfico de drogas e $13 \%$ por crimes contra a pessoa. Fazendo uma análise dos tipos penais isolados, o crime de roubo e tráfico de entorpecentes respondem sozinhos a $50 \%$ das sentenças condenatórias no país.

Todavia, segundo o relatório mais atual do Levantamento Nacional de Informações penitenciárias - INFOPEN de junho de 2016, o Brasil já é a terceira maior população carcerária do mundo, com 726.712 pessoas presas. O país só perde para a população carcerária da China e os Estados Unidos que ocupam o topo do ranking. Conforme informações desse relatório mais recente, $40 \%$ dos custodiados continuam sendo presos provisórios, mais da metade são de jovens entre 18 e 29 anos e $64 \%$ são negros. Dentro desse contexto, $89 \%$ estão em estabelecimentos superlotados (BRASIL, 2016).

Um ponto a ser salientado dentro desse contexto de explosão de encarcerados é o mau uso da legislação penal, relacionando-se com a lei 11.343/2006 (Lei de drogas), cuja má redação do texto vem gerando o mau uso pelos órgãos de repressão e o encarceramento em massa de algumas faixas etárias no país. Embora pareça que houve um avanço com o novo diploma no que diz respeito à despenalização do consumo pessoal de drogas ilícitas, prevendo outras medidas não encarceradoras para tal conduta, o que ocorre no plano prático é distorcido, uma vez que as medidas socioeducativas não ganharam efetividade.

Um dos pontos obscuros da referida lei é a subjetividade da redação, que possibilita às autoridades coatoras a utilização da lei de forma seletiva e arbitrária, bem como o aumento da pena em abstrato para o crime de tráfico de drogas, que passou da pena mínima de três anos para cinco anos (DIAS, 2013). Para afirmar o retrocesso da lei supracitada, dados demonstram a incidência de prisões pelo crime de tráfico de drogas antes da edição da lei, sendo em 2005 presas 31.520 pessoas por esse tipo penal e depois, em 2014 presas 174.216 pessoas, tornando o tráfico de drogas o crime que mais encarcera pessoas no Brasil, com cerca de $28 \%$ da população prisional total (INFOPEN, 2014).

Um adendo sobre a falência dos presídios brasileiros é a seletividade do sistema penal, uma vez que "um grupo determinado de pessoas acaba sendo alvo preferencial do encarceramento" (SANTOS, 2015, p. 81), essa seleção possui alguns filtros em razão de raça, gênero, condição socioeconômica e escolaridade. Em 2014, 61\% dos indivíduos aprisionados no Brasil eram negros. Isso é corroborado por Wacquant (1999, p. 6), 
quando cita "o recorte da hierarquia de classes e da estratificação etnorracial e a discriminação baseada na cor endêmica nas burocracias policial e judiciária”. Reitera que criminalizar a miséria é negar a problemática racial no Brasil com o aval do Estado, tornando as prisões campos de concentrações para os pobres. Quanto ao gênero dileto, a média de mulheres aprisionadas é de 5,8\% para 94,2\% de homens presos, deixando bem clara a estigmatização do homem enquanto criminoso. Outro filtro alarmante é o da escolaridade, já que $75 \%$ da população prisional só possuem o ensino fundamental completo (INFOPEN, 2014). Por isso, Wacquant enfatiza:

Nessas condições, o aparelho carcerário brasileiro só serve para agravar a instabilidade e a pobreza das famílias cujos membros ele sequestra e para alimentar a criminalidade pelo desprezo escandaloso da lei, pela cultura da desconfiança dos outros e da recusa das autoridades que ele promove (WACQUANT, 1999, p.7).

Com fulcro na Carta Magna, entende-se que a dignidade deve ser concedida a todos, independente da situação em que se encontrem, pois, o artigo $5^{\circ}$, inciso III, positiva que: "ninguém será submetido à tortura nem a tratamento degradante ou desumano". Contudo, denúncias de violações de direitos humanos dos presos são recorrentes, irregularidades na execução penal, problemas com a superlotação, maus tratos e condições precárias de higiene foram apuradas pela CPI do sistema carcerário brasileiro (BRASIL, 2017). A gravidade dessas violações e a situação sub-humana dos presos deram ensejo à apresentação de denúncia contra o país na Comissão Interamericana de Direitos Humanos (CIDH).

Além disso, a violação da dignidade humana e da integridade dos presos também foi pauta do Supremo Tribunal Federal (STF) em agosto de 2015, na Ação de Descumprimento de Preceito Fundamental (ADPF) 347, na qual o Ministro Marco Aurélio pediu a declaração de estado inconstitucional do sistema penitenciário (BRASIL, 2015). Em meados de 1970, na sua brilhante obra Vigiar e punir, Foucault afirmava a inviabilidade dessa sistemática das prisões, ao inquietar-se com os problemas carcerários da época:

Há um século e meio que a prisão vem sempre sendo dada como seu próprio remédio; a reativação das técnicas penitenciárias como a única maneira de reparar seu fracasso permanente; a realização do projeto corretivo como único método para superar a impossibilidade de toná-lo realidade (FOUCAULT, 2002, p. 223). 
Diante da letra morta das leis, da inércia do Estado, que não demonstra ser capaz de concretizar as finalidades da Lei de Execução Penal, e das inúmeras mazelas mencionadas, a situação dos "depósitos inumanos das classes marginalizadas" (MESQUISTA, 2017, p. 3) fez com que muitos caminhos fossem surgindo para tentar sanar o completo caos instalado pelo déficit de vagas, falta de recursos estatais e graves violações de direitos inerentes à pessoa humana. Em virtude do fracasso, surge "o gerencialismo penal como um reflexo desse esforço por uma distinta racionalização das práticas punitivas, obedecendo a esse novo paradigma assentado no campo criminal, pragmático e economicista" (SANTOS, 2017, p. 2). Assim, a intervenção privada na seara penal, enquanto forma de política penitenciária, retorna ao contexto prisional como pretensa solução adotada para tratar dos graves problemas existentes nos estabelecimentos penais por todo o país.

\section{O FENÔMENO DA GESTÃo PRIVADA NO SISTEMA PENITENCIÁRIO}

A partir de uma breve retrospectiva, observa-se que a intervenção privada na execução penal ocorreu desde a idade média, quando a Inglaterra, por exemplo, possuía sistemas prisionais particulares, cujo objetivo principal girava em torno do lucro através da exploração das atividades (PASSOS, 2016). No século XVI, surgiram as workhouses, que eram oficinas de trabalho, com o objetivo de ajudar os pobres, que trabalhavam em troca de habitação. Posteriormente, tornou-se um depósito daqueles que eram considerados indesejáveis. Como não havia recursos para manter as cadeias, as workhouses se transformaram numa prática lucrativa para os empresários da época. Foi dessa forma, que nasceu o protótipo da prisão privatizada (MESQUITA, 2017).

Já no século XVIII, o estudioso criador do Panótipo, Jeremy Bentham, defendeu a possibilidade de conceder, por meio de contrato, a administração das prisões aos agentes particulares. Nesse contrato deveria haver todas as especificidades acerca dos deveres do particular e do Estado sobre o preso, bem como a transparência financeira do contrato. Neste modelo de Bentham, o Estado não seria o único ator da justiça penal, pois concederia ao particular a exploração da atividade econômica nas prisões e, paralelamente, a obrigação de cuidado com o preso. Contudo, suas ideias não se 
difundiram de início, pois somente anos depois os EUA fez desse modelo a sua realidade (PASSOS, 2016).

Nessa época, as prisões funcionavam da seguinte forma: o trabalho dos condenados era alugado a empreendedores privados, que por sua vez, pagavam ao estado pelo uso de seus presos. O lucro era obtido pela venda de produtos confeccionados no mercado aberto. Somente no século XX esse tipo de contratação foi abolida e a era desse tipo de privatização findou. Enquanto isso, a privatização parcial (saúde, alimentação e educação) permaneceu sem que houvesse nenhum impedimento legal. Sob o novo sistema privado, as entidades seriam pagas pelo Estado para manter o preso sob sua custódia. Os defensores da privatização defendiam a capacidade do setor privado de ser mais inovador, eficiente e mais barato do que o público, sem afetar a qualidade dos serviços.

Em meados de 1980, uma discussão acadêmica vigorosa se iniciou, já que os críticos defendiam a ideia de que os gestores ficariam inclinados a cortar custos para auferir mais lucro, afetando a qualidade dos serviços prestados (CULP, 2005).

\subsection{Difusão da ideia no Brasil}

O "suculento mercado da punição" também chegou ao Brasil (WACQUANT, 1999, p. 36). Em 1992 foi apresentado no Conselho Nacional de Política Criminal e Penitenciária (CNPCP) uma das primeiras propostas para privatizar o sistema penitenciário no Brasil, mas a proposta não foi aprovada. Em 1999, o Deputado Federal Luis Barbosa apresentou Projeto de Lei n 2.146/99, que também não foi aprovado. Ainda assim, alguns Estados contrataram empresas privadas e concederam algum de seus serviços (MESQUITA, 2017).

Dessa forma, se baseando em experiências estadunidenses na década de 1980, o país deu início às práticas em 1999 no Paraná, na Penitenciária Industrial de Guarapuava, seguindo o modelo Francês e terceirizando alguns de seus serviços (CABRAL; AZEVEDO, 2012). Mesmo vivendo discussões jurídicas e políticas importantes sobre o assunto, atualmente o país vivencia a tendência da privatização, já experimenta os modelos de gestão prisional e mais de 20 penitenciárias com a participação privada estão distribuídas pelas unidades federativas de Santa Catarina, Espírito Santo, Bahia, Minas 
Gerais, Tocantins, Alagoas e Amazonas, diferindo apenas no grau de privatização (PASSOS, 2016).

Graças ao direito administrativo, a intervenção do particular tem se tornado uma prática cada vez mais constante na prestação dos serviços públicos, pois as demandas têm se tornado mais dispendiosas e complexas. Para fazer jus ao Estado social, com um perfil materializador dos direitos fundamentais da sociedade, os postulados clássicos do direito administrativo deram lugar a instrumentos mais flexíveis e práticos, como a privatização, que mais se assemelham com o direito privado. Decerto, o particular já é parte do sistema punitivo no Brasil, com diferentes graus de participação, uma vez que não seria permitida a privatização total e distintas formas contratuais (PINHEIRO, 2016).

Como destacam Sandro Cabral e Paulo Furquim de Azevedo (2012), há dois grandes modelos de privatização na gestão e operação prisional: o estadunidense e o francês. No primeiro modelo, o poder público afasta-se e o operador privado se envolve totalmente, desde a construção até a operação e gestão do presídio, cobrando do governo uma taxa diária por interno. Já no modelo francês, o operador privado fica responsável pela gestão do presídio no tocante à hotelaria e atividades de reinserção do indivíduo.

“Ao que parece, a privatização dos presídios foi o caminho escolhido pelos administradores públicos brasileiros em resposta à superlotação dos estabelecimentos prisionais" (PASSOS, 2016, p. 444), virando tendência através da edição da Lei 11.079/04 e, não menos importante, da Lei 8.666/93. Esses sistemas normativos tornaram possíveis novas formas do privado se relacionar com o Estado no que diz respeito à prestação dos seus serviços. A partir disso, dois modelos de gestão compartilhada são predominantes no Brasil: a cogestão, com contratos criados sob a égide da lei 8.666/93, no qual o Estado fica responsável pela direção do presídio, a guarda e a escolta externa, enquanto que a empresa privada fica responsável pela operacionalização da unidade.

Bem como a parceria público-privada, regida pela Lei 11.079/04, na qual os presídios são projetados, construídos, financiados e operados pela empresa privada, durante um longo período de tempo, sob a forma de concessão administrativa, na qual os custos são arcados exclusivamente pela Administração Pública, sem que haja cobrança de tarifas de seus usuários, que são os presos. Há características que distinguem o contrato de PPP dos demais contratos de concessões dos serviços públicos, sendo a mais importante delas o financiamento privado, já que um dos grandes problemas do ente público é a escassez de recursos para financiar obras e investimentos no âmbito prisional. 
Há também o compartilhamento dos riscos, ou seja, o ente público arca com prejuízos do negócio. Por último, a possibilidade de o estado garantir a sua contraprestação pecuniária de várias formas, como outorga de direitos e benefícios tributários (PASSOS, 2016).

Para Wacquant (1999), a mercantilização do preso vem prosperando por ter se tornado um negócio muito atraente, como demonstram as experiências estrangeiras e os fartos números da companhia Corrections Corporation of America ${ }^{4}$, cujos rendimentos em títulos no mercado de ações Nasdaq foram multiplicados por 40 em apenas 10 anos. Para se ter uma noção do quanto as prisões com fins lucrativos são rentáveis com base nesses números, a população carcerária das prisões privatizadas da Inglaterra passou de 200, em 1993, para quase 4.000 poucos anos depois.

Para demonstrar a forte tendência no país, tramita no Senado o Projeto de Lei $\mathrm{n}^{\circ}$ 513/11, que estabelece normas gerais para suprir as especificidades da contratação de parceria público-privada para a construção e administração de estabelecimentos penais. Esse projeto surge para tratar desses pontos mais específicos que não são encontrados na Lei 11.079, pois esta institui normas gerais para licitação e contratação de parceria público-privada no âmbito de toda a administração pública (SANTOS, no prelo). O referido PLS tem como pressuposto a desburocratização e a eficiência. Entretanto, os legisladores devem ser "suficientemente corajosos para enfrentar o tópico politicamente volátil dos lucros e as prisões" (HERIVEL; WRIGHT, 2013, p. 16), pois muitos foram os fracassos dessas práticas.

Essa tendência foi alvo de críticas por um bom tempo por não ter, segundo os seus opositores, respaldo legal no ordenamento jurídico brasileiro. Decerto, a atividade jurisdicional é dever do Estado, não podendo dela dispor ou delegar. A própria Lei 11.079, inciso III afirma a "indelegabilidade das funções de regulação, jurisdicional, do exercício do poder de polícia e de outras atividades exclusivas do Estado”.

Entretanto, essa crítica é desconstruída quando se compreende a permanência da atividade jurisdicional nas mãos do estado e a transferência da execução da pena e o auxílio material ao agente privado. Do ponto de vista legal, a própria LEP autoriza a participação dos particulares na execução penal. Quanto à Carta Maior, não há proibições na transferência dos serviços penitenciários para o empreendedor privado. O que pode gerar algumas dúvidas é o artigo 144 da Constituição, pois este afirma que é dever do

\footnotetext{
${ }^{4}$ Grande firma de encarceramento privado dos Estados Unidos.
} 
Estado promover a segurança nacional. Porém, esse artigo não se refere ao fornecimento dos serviços aqui mencionados, mas de polícia ostensiva e da ordem pública. (PASSOS, 2016).

\subsection{As principais formas de intervenção privada em âmbito prisional}

Da gestão pública até a privatização total pode ocorrer uma infinidade de variações nas formas de gestão dos presídios. A depender do país, a privatização pode se comportar de maneiras distintas e com diversidades nos seus arranjos contratuais. Como já mencionado de forma genérica, há dois modelos clássicos identificados: o americano e o francês. No modelo Norte-americano, o Estado se transforma num mero fiscalizador da lei quanto ao contrato firmado e os direitos concedidos aos presos, entregando totalmente a execução desse serviço ao particular. Logo, toda a gestão, direção e administração são entregues ao particular. Paulatinamente, uma característica negativa desse modelo seria a forma de remunerar o agente privado, que é em razão do número de presos, podendo ser indicativo de uma tendência encarceradora (PASSOS, 2016).

Como o próprio nome já esclarece, o Francês surgiu na França em 1987 com a sanção da lei 87.432, que deu ensejo a um projeto para a construção de 13.000 celas distribuídas em 25 prisões do país sob a responsabilidade do agente privado. O modelo apresenta características distintas do modelo anterior, já que há uma gestão compartilhada com o poder público, conforme prevê o contrato. Destarte, o ente público continuaria responsável pela gestão e segurança interna e externa das prisões e a indicação do diretor geral, sendo o particular, por meio de licitação, responsável por exercer funções definidas no edital, tais como "construção de unidades prisionais, fornecimento de alimentação, prestação de assistência social, médica, odontológica, psicológica e psiquiátrica, educação profissionalizante, esporte, recreação e prestação de assistência jurídica" (PASSOS, 2016, p. 437).

Segundo o relatório da Pastoral Carcerária de 2014, há dois modelos de privatização prisional praticados no Brasil: Cogestão e Parceria Público-Privada (PPP). A Cogestão é a modalidade que representa a maioria dos contratos firmados, de modo que o Estado assume a direção do estabelecimento, a guarda e a escolta externa, sendo responsabilidade da empresa privada que assume a operacionalização de toda a unidade. 
Já na PPP, as unidades são projetadas, construídas, financiadas, operadas e mantidas pelos agentes privados por um longo período de tempo, restando ao Estado a responsabilidade de fiscalizar a execução do contrato e a escolta externa.O relatório também trouxe dados de que, contando com a PPP de Ribeirão das $\mathrm{Neves}^{5}$, o Brasil já possui cerca de 30 prisões privatizadas.

Contudo, estudos mais recentes apontam que são 25 estabelecimentos prisionais funcionando em Cogestão e somente a Unidade de Ribeirão das Neves sob a forma de PPP. As empresas que atualmente são responsáveis por esses estabelecimentos são a Reviver, que atua no Estado de Alagoas, Sergipe, Bahia e Santa Catarina; Montesinos, em Santa Catarina e no Espírito Santo; Socializa, na Bahia; Umanizzare, em Tocantins e Amazonas e, por fim, a Gestores Prisionais Associados (GPA), que é a empresa responsável pela gestão da PPP em Minas Gerais ${ }^{6}$.

Vale destacar que, há diversas nomenclaturas para designar a participação privada nas prisões, mas o termo privatização utilizado em grande parte da literatura não pode ser traduzido de forma literal e empregado no Brasil de acordo com o modelo americano, uma vez que a privatização está atrelada a entrega total do serviço pelo Estado ao empreendedor privado, cuja prática é terminantemente proibida no país, por conta das limitações constitucionais. A própria justificativa do PLS no 513/2011 menciona que o termo mais adequado para essa prática seria a terceirização, pois não ocorre a desestatização total.

Para Sandro Cabral e Paulo Furquim de Azevedo (2012), os casos brasileiros são enquadrados, na verdade, em gestões mistas, que envolvem a iniciativa privada e a gestão pública, nas modalidades de terceirização e nas PPP's. Salientam também que, embora os casos brasileiros sejam mais baseados no modelo Francês, o que ocorre na verdade é uma mescla entre o modelo americano e o francês. Isso porque não foram delegadas totalmente ao agente privado todas as atividades, como a direção do estabelecimento

\footnotetext{
5 Parceria Público-Privada firmada em 2013 no estado de Minas Gerais, no complexo de Ribeirão das Neves, através de um consórcio com a empresa Gestores Prisionais Associados (GPA).

${ }^{6}$ Dados coletados em estudos vinculados à pesquisa que está sendo desenvolvida, com financiamento do Instituto de Pesquisa Econômica e Aplicada (IPEA), intitulada "Pensando o direito: identificação de atributos para a contratação de parceria público-privada ou cogestão na construção e administração de estabelecimentos penitenciários”. O projeto é coordenado pela Profa. Suzann Flávia Cordeiro de Lima (UFAL), juntamente com a participação do Prof. Hugo Leonardo Rodrigues Santos (UFAL), do Prof. Bruno Cavalcante Leitão Santos (CESMAC), entre outros pesquisadores.
} 
prisional, prática comum no americano e atividades não delegadas no modelo francês, foram delegadas no Brasil, como a assistência jurídica.

\subsection{Público versus Privado: os pontos favoráveis e as críticas à adoção dos modelos adotados no Brasil}

De início, cabe ressaltar que, embora existam diversas obras que fazem um cotejo crítico entre a gestão pública e a gestão com o privado, não há, até o presente momento resultados concretos quanto ao desempenho das gestões. Portanto, não há como mensurar qual opção é mais viável, restando apenas apontar os posicionamentos das literaturas sobre o tema (CABRAL; AZEVEDO, 2012). Isso porque a pesquisa em prisões encontra dificuldades quando esbarra na carência de transparência, não sendo muito diferente nos casos das prisões privadas, que não são subordinadas ao interesse público (HERIVEL; WRIGHT, 2013).

Levando em consideração os altos dispêndios na satisfação do interesse público por conta dos altos custos e pela falta de retorno da finalidade da pena, há quem defenda a adoção da PPP para balancear o custo e a qualidade dos serviços prestados, pois este se tornaria, em tese, mais barato e eficiente, isso por que "o setor privado teria menores dificuldades operacionais, já que o Estado necessita de licitações, o que acaba burocratizando e, consequentemente, precarizando o trabalho estatal" (GUEDES, 2010, p.70).

Dessa forma, o Brasil parece seguir uma tendência mundial de desestatizar dos serviços públicos, que vem dando certo em vários países, como Portugal, Espanha, Inglaterra e Irlanda, se fundando numa ideologia neoliberal. Os defensores alegam os graves problemas do sistema penitenciário, como a superlotação e a falta de investimentos na área, sob a alegação de que a adoção dessa prática penitenciária garantiria melhorias na estrutura dos serviços e concessão das assistências prevista na legislação, sem contar com a oferta de trabalho e educação para os presos (PINHEIRO, 2016).

Outro ponto positivo destacado seria a rapidez na obtenção e o não desperdício dos recursos, já que haveria necessidade de licitar como no setor público, fora que a liberação do dinheiro só aconteceria na medida em que o serviço fosse, de fato, prestado. Isso porque o pagamento fica condicionado à demonstração dos níveis de desempenho alcançados, sendo possível a redução ou até o não pagamento dos recursos, se o serviço 
não se mostrar satisfatório. O problema é que esses contratos de PPP são poucos utilizados, em virtude da sua alta complexidade jurídica e os valores necessários à sua concretização, pois seu valor mínimo é de 20 milhões de reais, bem como o seu prazo, que deve ser de no mínimo 5 anos e não mais que 35 anos. Fora que a instabilidade nas discussões da legalidade e viabilidade nessa prática a torna insegura para os investidores (PINHEIRO, 2016).

Todavia, muitas barreiras éticas, jurídicas a até políticas são colocadas pelos opositores dessa prática, uma vez que, do ponto de vista ético, não seria possível o objetivo lucrativo em virtude do trabalho do preso, o que é comum em prisões com interferências privadas. Sob a ótica jurídica, não seria possível a gestão do trabalho dos presos por agentes privados e, por fim, politicamente falando, essa experiência tem resultados fracassados em diversos países e não deveria ser implantado novamente. Além do mais, um dos princípios mais fortes da Administração Pública é relativizado, uma vez que a transparência nesses estabelecimentos é descaracterizada em virtude de confidencialidade da empresa (GUEDES, 2010).

Além disso, Santos (no prelo), se valendo da denúncia de José Adaumir Arruda da Silva, entende que as finalidades do sistema punitivo são descaracterizadas quando o objetivo lucrativo se mistura com a execução penal, cujo cerne é a ressocialização do indivíduo. Isso porque consta no contrato da única PPP em funcionamento no Brasil, o Complexo de Ribeirão das Neves, em Minas Gerais, a exigência de uma taxa de ocupação de $90 \%$ para que o Estado remunere, de forma integral, o empreendedor privado, fora que “a empresa privada irá receber mais do Estado quanto maior for o número de presos que trabalham, pois, assim, ela alcançaria certos indicadores” (GUEDES, 2010, p. 72). Um fato preocupante nesse aspecto é que essa forma de remunerar está presente no texto inicial do PLS N 513/2011, já que o pagamento será de acordo com as vagas os serviços prestados e números de custodiados.

Essa ideia também é defendida por Mesquita (2017) ao mencionar a impossibilidade de harmonização entre o interesse econômico dos agentes privados e os interesses dos apenados. A partir do pressuposto que o aumento do número de presos é diretamente proporcional ao aumento de incrementos, a gestão privada não poderia estar interessada em promover as finalidades penais, nem ter custos capacitando os seus funcionários, manter a qualidade dos serviços, de maneira que a meta seria controlar os gastos para auferir mais lucratividade. Além disso, muitas unidades foram construídas 
fora das diretrizes estabelecidas pelo Conselho Nacional de Política Criminal e Penitenciária (CNPCP), impossibilitando atividades diárias dos presos, como banhos de sol e exercícios físicos. Logo, perpetuar o encarceramento em detrimento das penas alternativas seria os resultados da adoção de tais medidas.

Os proponentes privatização alegam que o objetivo da gestão privada não será perpetuar a superpopulação carcerária, desde que seja adotado o modelo global quanto ao valor pago ao empreendedor privado pelo Estado, pois este ocorre em virtude da capacidade total do presídio, e não das vagas ocupadas. Assim, haveria um interesse por parte da gestão privada em querer garantir os direitos do preso, visando à sua saída do sistema prisional, de modo que ele não retorne e não ocorresse a reincidência, garantindo a ressocialização dos custodiados e, consequentemente, incremento nos seus lucros (PASSOS, 2016).

Por fim, outra crítica contundente apontada pela Pastoral Carcerária (2014), através dos gráficos e tabelas, é que um dos pilares da privatização, a economicidade, é equivocada. Tomando por exemplo o estado do Espírito Santo, no qual três empresas privadas que administram sete unidades prisionais, receberam mais de $\mathrm{R} \$ 70.000 .000,00$. Ao passo que o valor gasto pela Secretaria de Justiça do Espírito Santo foi de R\$ 320.743.588,49 em 2013, para o restante das 37 unidades prisionais públicas.

Dessa forma, o CNPCP, na sua Resolução No 08/2002, recomendou a reprovação de propostas que indiquem a privatização do sistema penitenciário, indicando que a segurança, a administração, a gestão e a disciplina não devem ser relegadas ao agente privado. Diante do exposto, é de suma importância analisar os resultados provenientes da privatização prisional, uma vez que muito se fala da crítica realidade do sistema, das suas mazelas e possíveis soluções, mas pouco são os estudos acerca dos efeitos dessa prática, principalmente no Brasil, talvez pelo pouco tempo de experiência. Assim, valendo-se de obras e estudos feitos em países que há mais tempo vivencia a participação privada na seara penal, algumas abordagens serão pertinentes para a conclusão desse estudo.

\section{OS REFLEXOS DA "NOVA" POLÍTICA CRIMINAL}

Inicialmente, é válido entender que há uma gama de empresas que, de fato, lucram com a atividade prisional, mas a "indústria das prisões privadas" nasce exclusivamente 
com a finalidade de lucrar com o encarceramento de pessoas. Há empresas que concorrem para equipar, gerir e utilizar a mão de obra dos presos, que cabe destacar, desprovida de proteção trabalhista, bem como fomentar a massa carcerária e manter os leitos ocupados. Além disso, esses empreendedores são, comumente, desprovidos de treinamento que a área penitenciária exige (HERIVEL; WRIGHT, 2013, p. 10).

Segundo Pinheiro (2016), a experiência americana demonstra que não é mera coincidência o fenômeno da privatização e o encarceramento em massa. No fluxo acelerado de encarceramento, os norte-americanos ocupam o primeiro lugar no ranking de pessoas presas, com mais de 2 milhões de detentos e essa expansão é a gênese da indústria da privatização. Para piorar, os resultados desse aprisionamento exacerbado deram ensejo a um déficit público, com $248 \%$ de aumento das prisões nos 10 primeiros anos de privatização, mudança do fluxo dos recursos sociais para a justiça criminal, incentivo à cultura punitivista, aumento do número de crimes em razão das altas taxas de reincidência e intensificação das desigualdades socias em virtude da seletividade penal, ou seja, problemas oriundos dos estabelecimentos penais públicos acompanham as prisões privadas.

Por ser um dos pioneiros em todo o mundo, cabe aqui demonstrar os resultados vivenciados pelos Estados Unidos. Um estudo empírico utilizou dados de arquivos e históricos, que incluem documentos administrativos e legislativos para identificar eventos na evolução da política de privatização entre 1983 até 2000, bem como relatórios da mídia sobre administração privada de prisões e deliberações legislativas de todo os Estados Unidos. Houve também uma análise secundária de dados sobre população prisional, ordens judiciais e prisões privadas de uma variedade de fontes. Por meio de uma retrospectiva histórica sobre a retomada da privatização prisional, foi constatado o aumento significativo da população carcerária da década de 1970, que desencadeou uma abertura das políticas de privatização na década de 1980, como remédio ao caos instalado nos cárceres americanos (CULP, 2005).

Segundo Culp (2005), os contratos firmados com os empreendedores privados nos Estados Unidos tiveram um aumento vertiginoso. Em 1990, eram 15.300 leitos privados, em 1999, já eram 145.600 leitos. Embora defenda que prisões privadas custem um pouco menos para operar do que as prisões públicas, sendo de $4 \%$ a $14 \%$ menos dispendiosas que as públicas, conclui-se que o auge da privatização desencadeou um aumento significativo nas taxas de encarcerados, elevando os gastos públicos com os investimentos 
prisionais. Esse fato eliminou muito das motivações por trás das políticas de privatização prisional. O fato é que a história da privatização prisional vem se repetindo há décadas em diversos países, só mudando o contexto em cada realidade, mas sempre com o mesmo intuito: o lucro, e onde estiver o lucro, os presos serão o meio para conduzir os objetivos mercadológicos dessas empresas.

Além disso, cabe mencionar que houve um recuo dessas práticas e uma perceptível mudança de paradigma na postura americana após alguns anos de experiência, quando um memorando foi editado pelo Departamento de Justiça dos EUA em 2016, baseado em um monitoramento no período entre 2011 e 2014, com contundentes afirmações de que as prisões privatizadas demonstraram resultados piores que as prisões administradas pelo poder público, tanto no que diz respeito à prestação de serviços e o aspecto da economicidade, como na falta de segurança e fiscalização efetiva desses estabelecimentos. Dessa forma, dúvidas começam a pairar sobre os grandes pilares da privatização. Confirmando as críticas do documento publicado, dias depois uma prisão privatizada no Mississipi foi fechada em virtude de corrupção e violência (SANTOS, 2017).

Dentro de um contexto escasso de estudos empíricos brasileiros que comparam o desempenho das formas de gestão prisional, a experiência baiana foi analisada. $\mathrm{O}$ Conjunto Penal de Teixeira de Freitas (CPTF), que é totalmente público e o Conjunto Penal de Valença (CPV), cujos serviços são terceirizados foram objetos de pesquisa no referido estudo. Dentre vários resultados obtidos, os indicadores de serviços chamam bastante atenção, pois assistência médica e odontológica do CPV apresentou um desempenho superior (10 vezes mais) em relação ao CPTF, bem como a assistência jurídica, que demonstrou ser 20 vezes maior no CPV. Umas das graves omissões estatais é a ineficiência de auxílio jurídico, que ocasiona, não raramente, negligências na concessão de direitos dos presos (CABRAL; AZEVEDO, 2012). Entretanto, Santos (2017) alerta sobre a repetição da problemática americana nessa fase das privatizações brasileiras, haja vista que a regulamentação jurídica dessa prática é insuficiente após 19 anos do primeiro estabelecimento administrado pelo ente privado.

\section{CONSIDERAÇÕES FINAIS}


Apesar do caos no sistema penitenciário não ser um fato recente, mas fruto de uma construção social, e problemas com a infraestrutura prisional, alimentação, assistências, higiene e altos índices de reincidência ser pontos críticos dos estabelecimentos penais, não há dados confiáveis e suficientes que confirmem a eficiência e a economicidade da privatização nas prisões como alternativa à referida realidade.

Em que pese existam diversas obras traçando a falência dos estabelecimentos prisionais e a problemática do crescente encarceramento, bem como a intervenção dos agentes privados para elucidar a situação e a escassez de recursos públicos, pouco se sabe sobre os reflexos da privatização em âmbito prisional no Brasil, devido ao pouco tempo de experiência e a falta de estudos empíricos, não há números que indiquem um liame entre o aumento do contingente prisional e a entrega da execução penal aos empreendedores privados.

Decerto, essa realidade vem ganhando força e adeptos no Brasil num cenário de dúvidas quanto aos reais efeitos da participação do ente privado na execução da pena. Dessa forma, medidas devem ser adotadas para que os resultados da experiência americana não sejam repetidos. Políticas desencarceradoras e incentivo à função ressocializadora da pena devem ser prioridades na execução penal dentro desse contexto da intervenção privada.

Uma proposta para evitar a tendência ao encarceramento em detrimento dos objetivos lucrativos seria a adoção do modelo global de remuneração por parte do Estado, cujo pagamento feito ao empreendedor privado não teria base na quantidade de presos, mas na capacidade total do estabelecimento prisional contratado, independentemente da taxa de leitos ocupados. Isso afastaria o suposto interesse mercadológico dos agentes privados em manter seus estabelecimentos lotados, ao passo que haveria o interesse em atingir os índices de desempenho de ressocialização, que por sua vez, se traduziria em queda nas taxas de reincidência, já que o empreendedor estaria visando os incrementos na sua remuneração. 


\section{REFERÊNCIAS BIBLIOGRÁFICAS}

ABRAMOVAY, Pedro Vieira. O grande encarceramento como produto de ideologia (neo) liberal. In: ABRAMOVAY, Pedro Vieira; BATISTA, Vera Malaguti (Org.) Depois do grande encarceramento. Rio de Janeiro: Revan, 2010.

BRASIL. CONSTITUIÇÃO DA REPÚBLICA FEDERATIVA DO BRASIL DE 1988. Disponível em:<

http://www.planalto.gov.br/ccivil_03/constituicao/constituicao.htm>. Acesso em: 02 jun. 2017.

LEI No 11.343, DE 23 DE AGOSTO DE 2006. Institui o Sistema Nacional de Políticas Públicas sobre Drogas - Sisnad; prescreve medidas para prevenção do uso indevido, atenção e reinserção social de usuários e dependentes de drogas; estabelece normas para repressão à produção não autorizada e ao tráfico ilícito de drogas; define crimes e dá outras providências. Disponível em: <

http://www.planalto.gov.br/ccivil_03/_ato2004-2006/2006/lei/111343.htm>. Acesso em: 02 jun. 2017.

. MINISTÉRIO DA JUSTIÇA. Levantamento Nacional de Informações

Penitenciárias: INFOPEN de dezembro 2014. Brasília: Departamento Penitenciário Nacional, 2015. Disponível em: <http://www.justica.gov.br/seus.-direitos/politicapenal/relatorio-depen-versao-web.pdf>. Acesso em: 21 jun. 2017.

MINISTÉRIO DA JUSTIÇA. Levantamento Nacional de Informações Penitenciárias: INFOPEN atualização em junho de 2016. Brasília, Departamento Penitenciário Nacional, 2017. Disponível em: <https://www.conjur.com.br/dl/infopenlevantamento.pdf >. Acesso em: 13 fev. 2018.

CONGRESSO NACIONAL. Comissão Parlamentar de Inquérito destinada a Investigar a Realidade do Sistema Carcerário Brasileiro. Brasília, 2017.

CONGRESSO NACIONAL. Projeto de Lei do Senado n 513 de 2011.

Estabelece normas gerais para a contratação de parceria público-privada para a construção e administração de estabelecimentos penais. Disponível em: < https://www25.senado.leg.br/web/atividade/materias/-/materia/101752>. Acesso em: 18 de jan. 2018.

. CONSELHO NACIONAL DE JUSTIÇA. Novo diagnóstico de pessoas presas no Brasil (2014). Disponível em:

<http://www.cnj.jus.br/images/imprensa/diagnostico_de_pessoas_presas_correcao.pdf $>$. Acesso em: 02 jun. 2017.

SUPREMO TRIBUNAL FEDERAL. Ação de Descumprimento de Preceito Fundamental (ADPF) 347. Relator Min. Marco Aurélio. Disponível em < http://redir.stf.jus.br/paginadorpub/paginador.jsp?docTP=TP\&docID=10300665 >. Acesso em: 17 jan. 2017.

LEI N 11.079, DE 30 DE DEZEMBRO DE 2004. Institui normas gerais para licitação e contratação de parceria público-privada no âmbito da administração pública. 
Disponível em:< http://www.planalto.gov.br/ccivil_03/_ato20042006/2004/lei/111079.htm>. Acesso em: 15 fev. 2018.

LEI No 8.666, DE 21 DE JUNHO DE 1993. Regulamenta o art. 37, inciso XXI, da Constituição Federal, institui normas para licitações e contratos da Administração Pública e dá outras providências. Disponível em:< http://www.planalto.gov.br/ccivil_03/Leis/L8666cons.htm>. Acesso em: 15 fev. 2018. CABRAL, Sandro; AZEVEDO, Paulo Furquim. Terceirização das prisões: notas de uma análise comparada. In: COELHO, Maria Tereza Ávila Dantas; CARVALHO FILHO, Milton Júlio (Org.) Prisões numa abordagem interdisciplinar. Salvador: EDUFBA, 2012, p. 53-73.

; LAZZARINI, Sergio. Impactos da Participação Privada no Sistema Prisional: Evidências a partir da Terceirização de Prisões no Paraná. RAC, Curitiba, v. 14, n. 3, art. 1, pp. 395-413, Mai./Jun., 2010.

CARVALHO, Salo de. O papel dos atores do sistema penal na era do punitivismo. Rio de Janeiro: Lumen Juris, 2010.

CULP, Richard. The Rise and Stall of Prison Privatization: An Integration of Policy Analysis Perspectives. In: Criminal Justice Policy Review, v. 16, n. 4, p. 412-442, Dezembro 2005.

DIAS, Gabriel Bulhões Nóbrega. Encarceramento em massa: produto da relação entre as políticas carcerária e proibicionista. In: Revista Trangressões: Ciências Criminais em Debate, Rio Grande do Norte, v. 1, n. 1, p. 89-108, jan.-mar. 2013.

FOUCAULT, Michel. Vigiar e punir. Trad. Raquel Ramalhete. Petrópolis: Vozes, 2002.

GUEDES, Cristiane Achilles. A Parceria Público-Privada no sistema prisional. In: Revista do CAAP. Belo Horizonte, p. 65-76, jan-jun 2010.

HERIVEL, Tara; WRIGHT, Paul. Quem lucra com as prisões: O negócio do grande encarceramento. Rio de Janeiro: Revan, 2013.

IBCCRIM. Desencarceramento em massa. In: Editorial do Boletim IBCCRIM. Ano 25, n 293, Abril. São Paulo: IBCCRIM, 2017.

MESQUITA, Luisa Angélica Mendes. Análise crítica da privatização do cárcere como solução aos problemas penitenciários. In: Revista transgressões: Ciências criminais em debate. São Paulo, v. 5, n. 2, maio 2017.

PASSOS, Anderson Santos. Os particulares na execução penal: a privatização de estabelecimentos prisionais no Brasil sob uma perspectiva Jurídico-Constitucional. In: ANTUNES, Maria João; SANTOS, Cláudia Cruz; AMARAL, Cláudio do Prado (Org.). Os Novos Atores da Justiça Penal. São Paulo: Almedina, 2016.

PASTORAL CARCERÁRIA NACIONAL. Prisões privatizadas no Brasil em debate. Coordenação de obra coletiva: José de Jesus Filho e Amanda Hildebrand Oi. São Paulo: 
ASAAC, 2014. Disponível em: <http://carceraria.org.br/wpcontent/uploads/2014/09/Relato\%CC\%81rio-sobre-

privatizac\%CC\%A7o\%CC\%83es.pdf>. Acesso em: 13 set. 2017.

PINHEIRO, Lucas Corrêa Abrantes. Parcerias Público-Privadas no Sistema Prisional Brasileiro: o Particular como Novo Ator e as implicações desse modelo. In: ANTUNES, Maria João; SANTOS, Cláudia Cruz; AMARAL, Cláudio do Prado (Org.). Os Novos Atores da Justiça Penal. São Paulo: Almedina, 2016.

SANTOS, Hugo Leonardo Rodrigues. O discurso de criminalização da pobreza no Brasil: Recepção da política criminal de tolerância zero e suas repercussões. In: SANTOS, Hugo Leonardo Rodrigues. Estudos críticos de criminologia e direito penal. Rio de Janeiro: Lumen Juris, 2015, p. 81-106.

Gerencialismo e Privatização do Sistema Penitenciário Brasileiro: o caso da cogestão prisional. No prelo.

SANTOS, Ronny Peterson Nunes. Privatização de Presídios no Brasil: reflexões à luz de um possível recuo da experiência americana. Dossiê Especial Encarceramento em massa. Revista Brasileira de Ciências Criminais, v. 129, ano 25, p. 375-405. São Paulo: RT, 2017.

SÃO PAULO. RESOLUÇÃO N. ${ }^{\circ}$ 08, de 09 de Dezembro de 2002. Disponível em: <http://www.criminal.mppr.mp.br/arquivos/File/ExecucaoPenal/CNPCP/n8de9dez2002. pdf>. Acesso em: 07 jan. 2018.

WACQUANT, Löic. As prisões da miséria. Rio de Janeiro: Jorge Zahar, 1999.

ZAFFARONI, Eugenio Raúl. A Questão Criminal. Rio de Janeiro: Revan, 2013. 